\title{
New methodologies for in vitro analysis of binding and functional activity of sigma receptor ligands
}

James A. Fishback

West Virginia University

Follow this and additional works at: https://researchrepository.wvu.edu/etd

\section{Recommended Citation}

Fishback, James A., "New methodologies for in vitro analysis of binding and functional activity of sigma receptor ligands" (2011). Graduate Theses, Dissertations, and Problem Reports. 4712.

https://researchrepository.wvu.edu/etd/4712

This Dissertation is protected by copyright and/or related rights. It has been brought to you by the The Research Repository @ WVU with permission from the rights-holder(s). You are free to use this Dissertation in any way that is permitted by the copyright and related rights legislation that applies to your use. For other uses you must obtain permission from the rights-holder(s) directly, unless additional rights are indicated by a Creative Commons license in the record and/ or on the work itself. This Dissertation has been accepted for inclusion in WVU Graduate Theses, Dissertations, and Problem Reports collection by an authorized administrator of The Research Repository @ WVU.

For more information, please contact researchrepository@mail.wvu.edu. 
NEW METHODOLOGIES FOR IN VITRO ANALYSIS OF BINDING AND

FUNCTIONAL ACTIVITY OF SIGMA RECEPTOR LIGANDS

\begin{abstract}
James A. Fishback
A dissertation submitted to the School of Pharmacy at

West Virginia University in partial fulfillment of the requirements for the degree of
\end{abstract}

Doctor of Philosophy

in

Pharmaceutical and Pharmacological Sciences

Rae R. Matsumoto, Ph.D., Chair

Teruo Hayashi, Ph.D.

Jeffrey S. Fedan, Ph.D.

Peter Gannett, Ph.D.

Jason D. Huber, Ph.D.

Department of Basic Pharmaceutical Sciences

Morgantown, West Virginia

2011

Keywords: Sigma receptors, BiP, radioligand, competition binding, 96-well filtration, scintillation proximity assay (SPA), Alphascreen. 


\section{ABSTRACT \\ New methodologies for in vitro analysis of binding and functional activity of sigma receptor ligands}

\section{JAMES A FISHBACK}

Sigma receptors represent a promising drug development target for a number of therapeutic indications including cancer, depression, psychostimulant abuse and stroke. To date, two subtypes of sigma receptors have been identified; $\sigma 1$ and $\sigma 2$. Their respective roles in normal physiology and in disease processes are a subject of ongoing studies. Consequently, the discovery and development of subtype specific agonist and antagonist ligands remains a key research goal. To date, no in vitro functional assay suitable for routine screening of putative sigma ligands has been reported. As a result, radioligand binding assays are used as a primary screen. Therefore, to support the critical role of receptor binding assays, a new $\sigma 1$ selective radioligand, $\left[{ }^{3} \mathrm{H}\right]-\mathrm{SN} 56$, was characterized, and efforts were undertaken to develop medium throughput methods for binding affinity determinations for both sigma receptor subtypes. To fill the unmet need for an in vitro functional assay for $\sigma 1$ ligands, preliminary studies were performed to develop an immunological assay based on the ligand sensitive interaction of $\sigma 1$ and binding immunoglobulin protein (BiP). The results of the studies with $\left[{ }^{3} \mathrm{H}\right] \mathrm{SN} 56$ show that it possesses high affinity and selectivity for $\sigma 1$ receptors and offers considerable advantages over the currently used radioligand, $\left[{ }^{3} \mathrm{H}\right](+)$ pentazocine. Competition binding studies with established sigma ligands assayed in rat brain homogenates labeled with $\left[{ }^{3} \mathrm{H}\right] \mathrm{SN} 56$ or $\left[{ }^{3} \mathrm{H}\right](+)$-pentazocine yielded comparable $\mathrm{K}_{\mathrm{i}}$ values, indicating that the two radioligands bind the same site. Saturation studies revealed similar $\mathrm{B}_{\max }$ values for $\left[{ }^{3} \mathrm{H}\right] \mathrm{SN} 56$ and $\left[{ }^{3} \mathrm{H}\right](+)$-pentazocine, further supporting the notion that both ligands bind specifically to the site identified as the $\sigma 1$ receptor. Conventional radioligand binding studies for sigma receptors utilize a "cell harvester." Newer medium and high throughput technologies exist that have been applied to the analysis of numerous classical receptors. 96-well filtration and scintillation proximity assay (SPA) were evaluated for the analysis of sigma receptor ligand binding. Adaptation of the conventional binding assay to the higher throughput methods required the use of rat liver membranes because sigma receptor densities were too low in rat brain membranes to support reliable filtration in the 96-well format or use with SPA. Analysis of a series of reference compounds by 96-well filtration yielded binding affinities that correlated with values measured using the conventional method, for both sigma receptor subtypes. Following validation with the reference compounds, the 96-well filtration procedure was successfully used to determine $\mathrm{K}_{\mathrm{i}}$ values for sigma receptors for a novel series of 2(3)-benzothiazolones. Studies with SPA demonstrated that this technique also yields results that are equivalent to the conventional method, but the cost of beads is prohibitively high with currently available radioligands used in conjunction with tissue derived membranes; this cost could potentially be significantly reduced if higher specific activity radioligands were available or if membranes from cells overexpressing sigma receptors were utilized. Preliminary studies were performed to assess the feasibility of developing a high throughput in vitro functional assay for the $\sigma 1$ receptor using Alphascreen as a read-out of agonist induced disruption of the $\sigma 1 / \mathrm{BiP}$ complex. These efforts, which included a basic assessment of the Alphascreen platform, and attempts to determine if endogenous or recombinant proteins could serve as suitable substrates, were largely unsuccessful. However, these experiments did yield information that should prove useful for future development of an in vitro functional assay based on this protein-protein interaction. 


\section{ACKNOWLEDGEMENTS}

First and foremost, I would like to thank my friends and family, who have always given love and support in every circumstance.

My deepest gratitude goes to my advisor, Dr. Rae R. Matsumoto, for providing me an opportunity to pursue my $\mathrm{PhD}$ in her laboratory, and for her support, guidance and encouragement throughout my graduate studies.

I would also like to acknowledge my committee members, Dr. Jeffrey S. Fedan, Dr. Peter Gannett, Dr. Teruo Hayashi, and Dr. Jason D. Huber, for their insight and suggestions. I am particularly indebted to Dr. Hayashi who has made so many contributions to the field of sigma receptor research and graciously shared his knowledge with me both in person and through his extensive literature.

I also extend gratitude to all the faculty, staff and graduate students of the department of Basic Pharmaceutical Sciences for their help, discussions and friendships.

Because my graduate career began at the University of Mississippi, I also wish to thank my Master's committee members, Dr. Chris R. McCurdy, Dr. Anthony J. Verlangieri, and Abir T. El-Alfy. And a very special thanks to Dr. I. Wade Waters, whose enthusiasm for all things living and still gave me inspiration to marshal on when things got tough. 


\section{TABLE OF CONTENTS}

ABSTRACT

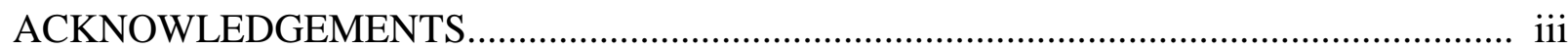

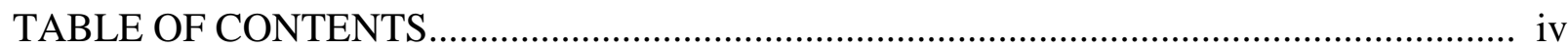

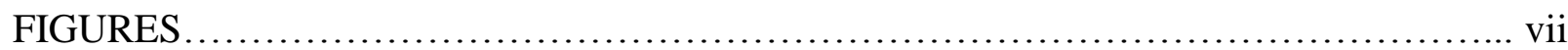

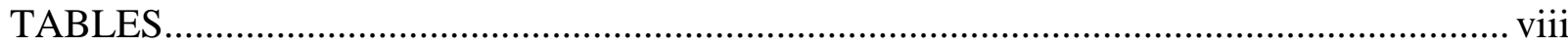

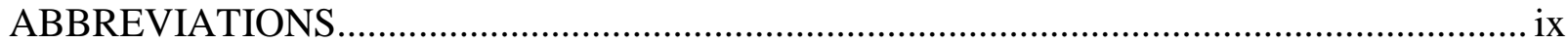

CHAPTER 1. Background and objectives............................................ 1

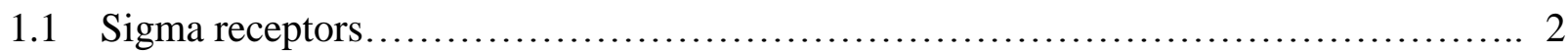

1.2 Utility of radioligands and radioligand binding methods in sigma receptor research..... 3

$1.3 \sigma 1$ selective radioligands.............................................................. 3

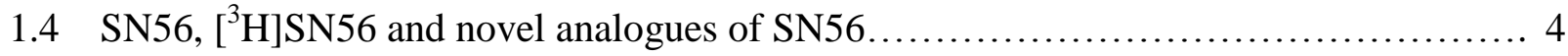

1.5 Medium and high throughput binding methods................................... 4

1.6 Binding of sigma ligands in mammalian liver versus brain derived isolates............. 5

$1.7 \mathrm{Ca}^{2+}$ and ligand sensitive interaction of $\sigma 1$ with binding immunoglobulin............... 6

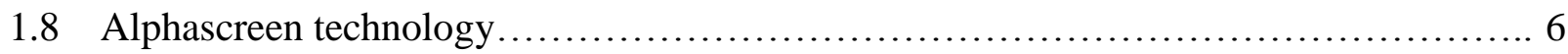

1.9 Applications for high throughput methods in sigma receptor research................... 7

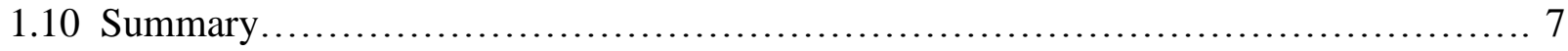

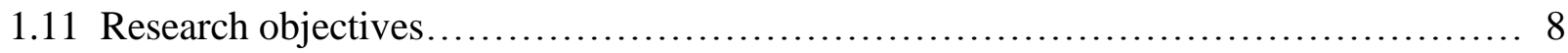

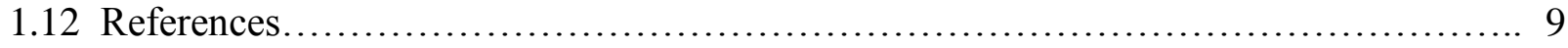

CHAPTER 2. $\left[{ }^{3} \mathrm{H}\right] \mathrm{SN} 56$, A novel radioligand for the $\sigma 1$ receptor......................... 19

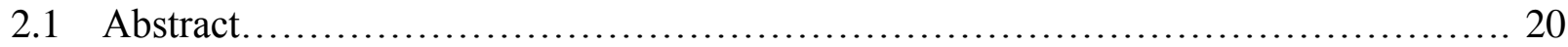

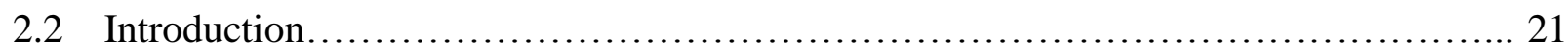

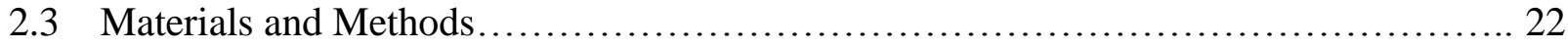

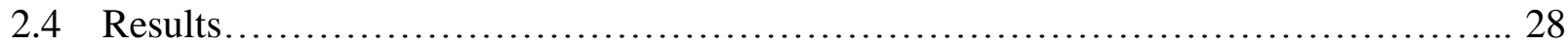




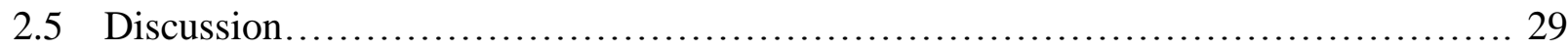

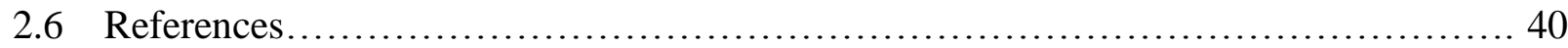

CHAPTER 3. A 96-well filtration method for radioligand binding analysis of sigma receptor

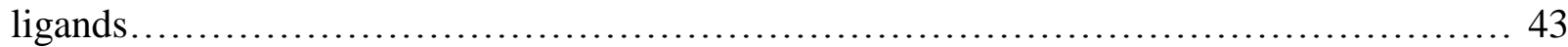

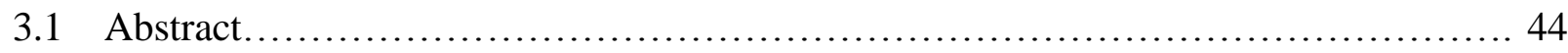

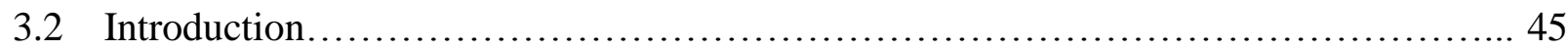

3.3 Materials and Methods........................................................... 48

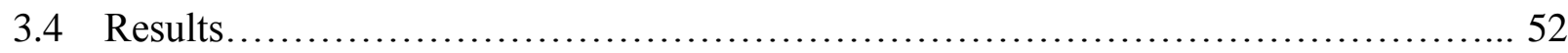

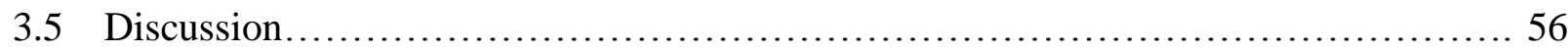

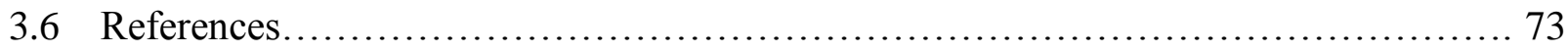

CHAPTER 4. A scintillation proximity assay (SPA) for radioligand binding analysis of sigma

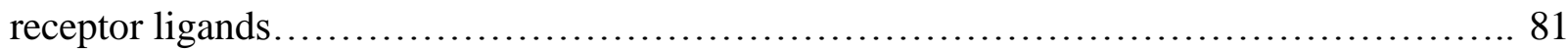

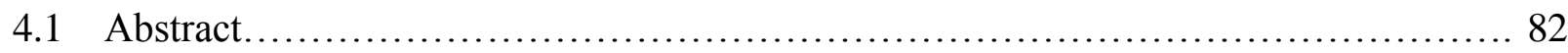

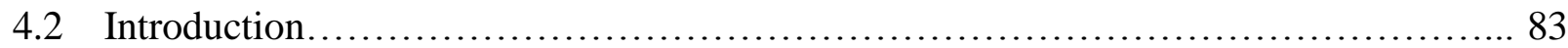

4.3 Materials and Methods............................................................. 84

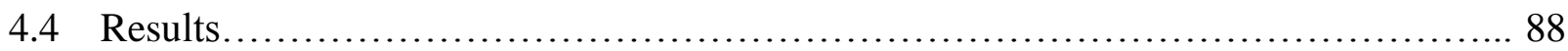

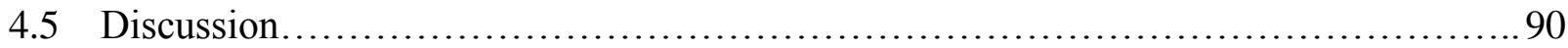

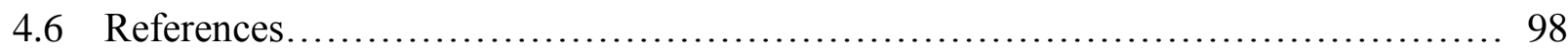

CHAPTER 5. Development of an Alphascreen assay for the determination of the in vitro

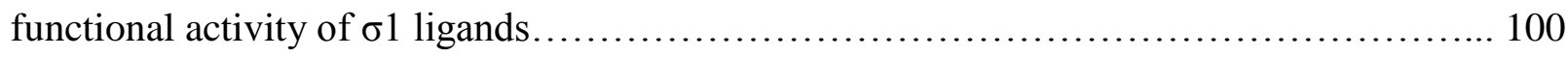

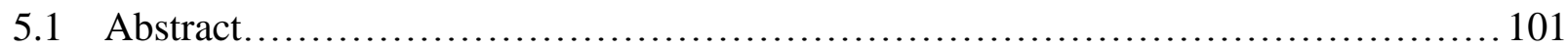

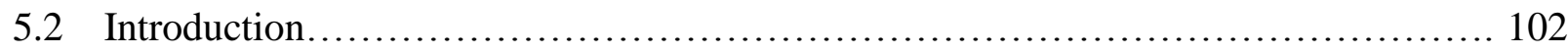

5.3 Materials and Methods........................................................ 107

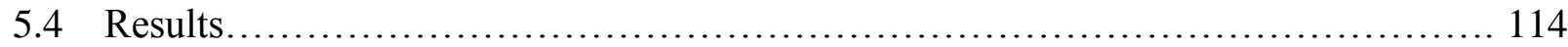

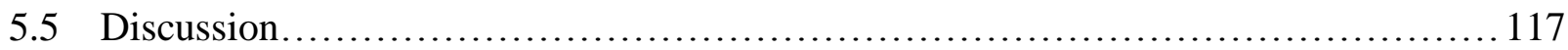




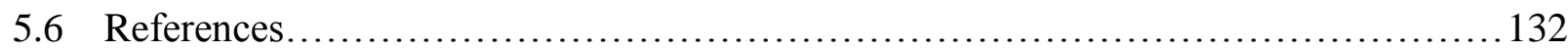

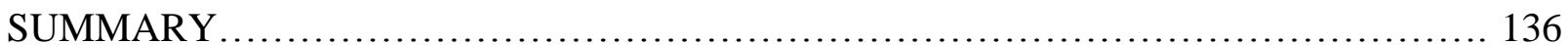

CURRICULUM VITAE..................................................... 138 


\section{FIGURES}

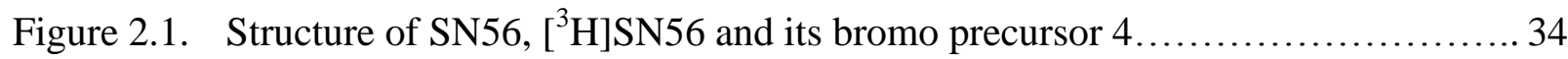

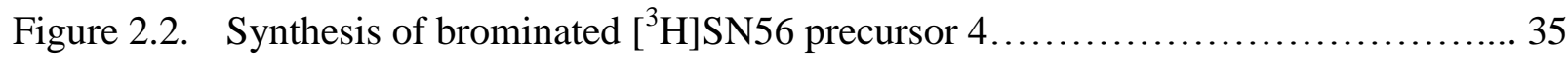

Figure 2.3. Binding linearity for $\left[{ }^{3} \mathrm{H}\right] \mathrm{SN} 56$ with rat brain $\mathrm{P} 2$ membranes................. 36

Figure 2.4. Saturation binding of $\left[{ }^{3} \mathrm{H}\right] \mathrm{SN} 56$ with rat brain P2 membranes................ 37

Figure 2.5. Correlation plot for binding of reference ligands to $\sigma 1$ receptors labeled with

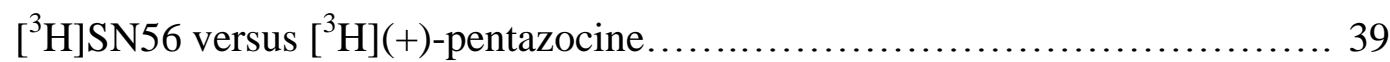

Figure 3.1. Binding linearity for $\sigma 1$ receptors in rat liver $\mathrm{P} 2$ membranes................6 63

Figure 3.2. Binding linearity for $\sigma 2$ receptors in rat liver P2 membranes................. 64

Figure 3.3. Correlation plots for binding of reference ligands to $\sigma 1$ receptors.............67 67

Figure 3.4. Correlation plots for binding of reference ligands to $\sigma 2$ receptors..............68

Figure 3.5. Structure of $2(3 \mathrm{H})$-benzothiazolone sigma ligands....................... 70

Figure 3.6. Binding affinity versus lipophilicity for $2(3 \mathrm{H})$-benzothiazolone sigma ligands...72

Figure 4.1. Binding of $\left[{ }^{3} \mathrm{H}\right](+)$-pentazocine to rat liver P2 membranes with five SPA bead

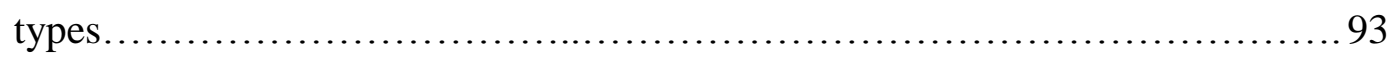

Figure 4.2. Binding linearity of $\left[{ }^{3} \mathrm{H}\right](+)$-pentazocine to rat liver P2 membranes with PVT WGA

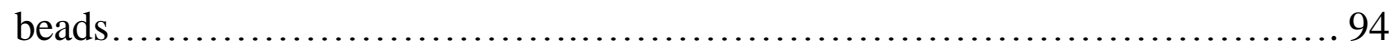

Figure 4.3. Binding of $\left[{ }^{3} \mathrm{H}\right] \mathrm{DTG}$ to rat liver P2 membranes with PVT WGA beads......... 95

Figure 4.4. Competition binding curves for DTG, haloperidol and (+)-pentazocine at $\sigma 1 \ldots 96$

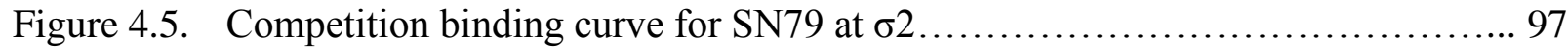

Figure 5.1. General scheme for detection of a $\sigma 1 / \mathrm{BiP}$ complex using an ELISA platform.. 124

Figure 5.2. General scheme for Alphascreen detection of $\sigma 1-F L A G / B i P$ complex......... 124

Figure 5.3. Binding of $\left[{ }^{3} \mathrm{H}\right](+)$-pentazocine to rat liver $\mathrm{P} 2$ membranes and solubilized P2 membranes........................................................... 125

Figure 5.4. Western blot following attempt to capture $\sigma 1$ from $\mathrm{CHO}$ cell lysates.......... 126

Figure 5.5. Titration of Alphascreen beads with control peptide..................... 127

Figure 5.6. Effect of additives and ligands on Alphascreen signal with control peptide...... 128

Figure 5.7. FLAG pulldown of $\sigma 1-$ FLAG and BAP-FLAG........................ 130

Figure 5.8. Procedure for preparation of $\sigma 1 / \mathrm{MAM}$ enriched fractions with Tx-114....... 131 


\section{TABLES}

Table 2.1. Binding affinities of reference ligands to $\sigma 1$ receptors labeled with $\left[{ }^{3} \mathrm{H}\right] \mathrm{SN} 56$ versus

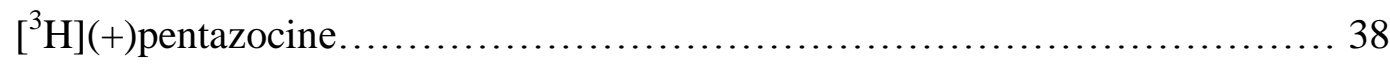

Table 3.1. Binding of $\left[{ }^{3} \mathrm{H}\right](+)$-pentazocine with rat brain $\mathrm{P} 2$ membranes processed by 96 -well

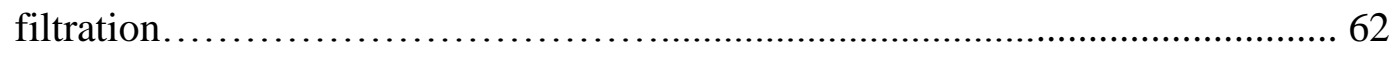

Table 3.2. Binding affinities of reference ligands at $\sigma 1$ receptors.......................65

Table 3.3. Binding affinities of reference ligands at $\sigma 2$ receptors.......................66

Table 3.4. Binding affinities of 2(3H)-benzothiazolone sigma ligands.................6 69

Table 3.5. $\quad$ LogD values for $2(3 \mathrm{H})$-benzothiazolone sigma ligands..................... 71

Table 5.1. Alphascreen signal produced by o1-FLAG and 6XHis-BiP versus control

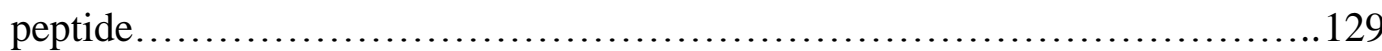




\section{ABBREVIATIONS}

ABTS - 2,2'-azino-bis(3-ethylbenzothiazoline-6-sulfonic) acid

ATCC - American Type Culture Collection

EDTA - ethylenediaminetetraacetic acid

EYFP - Enhanced yellow fluorescent protein

FDA - Food and Drug Administration

GST - glutathione S-transferase

HOP - Heat shock organizing protein

HRP - Horse radish peroxidase

Hsp90 - Heat shock protein 90

HTS - High throughput screening

$\mathrm{IP}_{3}$ - Inositol triphosphate

MAM - Mitochondrial associated membrane

NCGC - National Institutes of Health Chemical Genomics Center

PBS - Phosphate buffered saline

PC - Phosphatidylcholine

PEI - Polyethyleneimine

PET - Positron emission tomography

PVT - Polyvinyltoluene

RT - Room temperature

SPA - Scintillation proximity assay

SPECT - Single photon emission computed tomography

SPR - Surface plasmon resonance

Tris - Tris(hydroxymethyl)aminomethane

UPR - Unfolded protein response

WGA - Wheat germ agglutinin 


\section{CHAPTER 1}

\section{Background and objectives}




\subsection{Sigma receptors}

The sigma receptor was first described as a subtype of opioid receptors based on behavioral observations in dogs following administration of the benzomorphan, $\mathrm{N}$-allylnormetazocine (SKF10,047) [1]. Subsequent in vitro observations indicated that this binding site represented a new class of non-opioid receptor [2, 3]. Sigma receptors are widely distributed in the body with significant concentrations in most major organs, including the brain, heart, liver, kidney and spleen [4-8]. In the brain, they are found predominantly in structures associated with limbic and endocrine function, including the hippocampus, frontal cortex, hypothalamus, and olfactory bulb $[9,10]$.

Two subtypes of sigma receptors, $\sigma 1$ and $\sigma 2$, have been identified based on differences in pharmacological profile, tissue distribution, and molecular characterization [6, 11-15]. Their respective roles in normal physiology and in disease processes are a subject of ongoing pharmacological studies. The successful cloning, recent advances in the understanding of the functional role of $\sigma 1$ at the molecular level, and the availability of $\sigma 1$ subtype specific ligands provide some of the necessary tools for rational therapeutic targeting of this ubiquitous protein. However, existing knowledge of $\sigma 2$ is more limited, rendering specific targeting of this subtype problematic.

The $\sigma 1$ receptor is a highly conserved 223 amino acid protein that has been cloned from several species, including rodents and humans [16-20]. Functionally, $\sigma 1$ receptors appear to operate primarily via protein-protein interactions and have been shown to modulate the activity of various ion channels and signaling molecules [21]. $\sigma 1$ receptors are expressed on the endoplasmic reticulum (ER) and can translocate between different cellular compartments in response to ligand binding [22-24]. Accordingly, the discrete activities that are ascribed to the $\sigma 1$ receptor depend on its cellular location. $\sigma 1$ mediated modulation of ion channels on the plasmalemma [25-30] and control of intracellular calcium via interactions with inositol trisphosphate $\left(\mathrm{IP}_{3}\right)$ receptors on the ER are well documented [31-35]. The endogenous ligand(s) for $\sigma 1$ have yet to be conclusively identified; however, a number of candidates have been proposed, including some neuroactive steroids, sphingolipids, and most recently $N, N$ dimethyltryptamine [36-38]. 
Considerably less is known about the $\sigma 2$ receptor because selective ligands for this subtype have not been available, and attempts to isolate the protein have been unsuccessful [39, 40]. Efforts over the last decade to develop $\sigma 2$ specific ligands have met with some success, enabling more concise determinations of $\sigma 2$ specific effects [41-43]. Sigma receptors, particularly $\sigma 2$ are overexpressed in cancer cells and $\sigma 2$ agonists can inhibit their proliferation and induce apoptotic cell death by altering cytosolic $\mathrm{Ca}^{2+}$, ceramide and sphingolipid levels [42, 44, 45]. Because $\sigma 2$ receptors are overexpressed in cancer cells they can function as endogenous markers for proliferating tumors. Consequently, considerable effort has been expended in developing $\sigma 2$ specific radioprobes for SPECT (single-photon emission computed tomography) and PET (positron emission tomography) imaging [46-49].

\subsection{Utility of radioligands and radioligand binding methods in sigma receptor research}

Application of in vitro binding studies with sigma receptor specific radioligands has resulted in: 1) identification of sigma receptors as unique non-opioid receptors [2, 3], 2) identification of two sigma receptor subtypes, $\sigma 1$ and $\sigma 2$ [12-14], 3) delineation of their anatomical distributions [4, 50-52], and 4) determination of binding affinities of novel compounds. More recent reports show significant interest in the development of sigma subtype specific radioligands for PET and SPECT imaging [46-49, 53-56]. These imaging agents may prove useful in: 1) mapping sigma receptors in the human brain, 2) the diagnosis of cancer [48, 53, 56], Alzheimer's and Parkinson's disease [55], and 3) in the evaluation of antidepressant therapeutics [54].

\section{3. $\sigma 1$ selective radioligands}

DeCosta et al. [57] first described $\left[{ }^{3} \mathrm{H}\right](+)$-pentazocine, a highly selective radioprobe for $\sigma 1$ receptors. Subsequent studies demonstrated that $\left[{ }^{3} \mathrm{H}\right](+)$-pentazocine labeled a single class of sites in guinea-pig brain that correlated with the profile observed following labeling with the prototypic sigma probe [ $\left.{ }^{3} \mathrm{H}\right](+)-3-\mathrm{PPP}((+)-3-(3-h y d r o x y p h e n y l)-\mathrm{N}-(1-p r o p y l)-p i p e r i d i n e)$ [58]. $\left[{ }^{3} \mathrm{H}\right](+)$-Pentazocine exhibits low levels of non-specific binding and high affinity for $\sigma 1$ receptors $\left(\mathrm{K}_{\mathrm{d}}=4.8 \pm 0.4 \mathrm{nM}\right)$, with an over 700 -fold preference for the $\sigma 1$ over the $\sigma 2$ subtype [58]. Since the introduction of $\left[{ }^{3} \mathrm{H}\right](+)$-pentazocine, no alternative has been introduced that demonstrates superior $\sigma 1$ selectivity and specificity. A number of new radioligands have been proposed, but each of them has shortcomings: $\left[{ }^{3} \mathrm{H}\right]$ BHDP (N-benzyl-N'-(2-hydroxy-3,4-dimethoxybenzyl)- 
piperazine) demonstrates moderate affinity for $5-\mathrm{HT}_{2 \mathrm{~B}}$ receptors $\left(\mathrm{IC}_{50}=190 \mathrm{nM}\right)$, while $\left[{ }^{3} \mathrm{H}\right] \mathrm{SA} 4503$ (1-(3,4-dimethoxyphenethyl)-4-(3-phenylprophyl) piperazine) lacks subtype selectivity, with only 14-fold higher affinity for $\sigma 1$ versus $\sigma 2$ reported for unlabeled SA4503, and $\quad\left[{ }^{3} \mathrm{H}\right]-\mathrm{MS} 377 \quad((\mathrm{R})-(+)-1-(4-c h l o r o p h e n y l)-3-[4-(2-m e t h o x y e t h y l) p i p e r a z i n-1-y l] m e t h y l-2-$ pyrrolidinone L-tartrate) displays slow association kinetics, which renders its routine use impractical [59-62]. In recent years, the availability and quality of commercially available $\left[{ }^{3} \mathrm{H}\right](+)$-pentazocine has become unreliable, creating some urgency for the development of an acceptable alternative radioligand for $\sigma 1$ receptors. $\left[{ }^{3} \mathrm{H}\right](+)$-Pentazocine also demonstrates instability that manifests in increased non-specific binding as the material ages.

\subsection{SN56, $\left[^{3} \mathrm{H}\right] \mathrm{SN} 56$, and novel analogues of SN56}

SN56 (3-(2-(azepan-1-yl)ethyl)-6-propylbenzo[d]thiazol-2(3H)-one) was recently identified as a highly selective and subtype-specific ligand with subnanomolar affinity for $\sigma 1$ receptors [63]. Because of its high affinity and unique selectivity profile, SN56 was chosen for evaluation as a tritiated radioligand for use in competition binding assays. Additionally, a series of analogues of SN56 were synthesized by collaborators (Rohit Bhat in the lab of Dr. Christopher McCurdy, University of Mississippi, University, MS) to further delineate relationships between structure and binding affinity among this class of compounds. Three general themes were explored in this benzothiazolone series which include variations in: 1) the size of the attached heterocycle, 2) the heterocycle linker chain length, and 3) the composition of the alkyl or acyl chain at position 6 of the benzothiazolone system. This series of compounds were analyzed as part of this dissertation using the medium throughput 96-well filtration binding method described in this document.

\subsection{Medium and high throughput binding methods}

Instrumentation and materials have been developed for higher throughput receptor binding analyses employing filtration and scintillation proximity assays (SPA) in 96-well formats. These assays are in widespread use in binding experiments with membrane bound receptors (e.g. serotonin, opioid, somatostatin, acetylcholine) derived from tissue, and cultured cell-derived membranes [64-68]. In addition to increasing throughput, these assay technologies have the potential to improve assay accuracy and precision, and reduce costs relative to conventional filtration based assays [68-73]. Filtration assays in the 96-well format are operationally 
equivalent to conventional filtration assays except that reduced sample sizes are utilized and 96well specific cell harvesters and scintillation counters that can accommodate the 96-well format are employed for sample processing. Scintillation proximity assays (SPA) utilize scintillant containing microscopic beads which produce photons when radiolabeled molecules are in close proximity to the bead surface [70,74]. Cell membranes associate with the beads via interactions between wheat germ agglutinin bound to the bead surface and cell membrane glycosylation sites $[70,74]$. Binding of radioligands to receptors present in the membranes and associated with the treated bead surface give rise to a signal commensurate with the amount of bound radioligand [70, 74]. Published reports of the use of 96-well filtration in the analysis of sigma receptor binding are limited to two research groups, the Mach group from Washington University [75-78] and the Wünsch group from the University of Münster [79, 80]; therefore, it is apparent that the technique is not in widespread use in the sigma receptor field. To date no reports of the use of SPA in the analysis of sigma receptor ligands have been published in the literature.

\subsection{Binding of sigma ligands in mammalian liver versus brain derived isolates}

Development of higher throughput methods for analysis of binding of sigma receptors requires higher densities of sigma receptors than are expressed in rat or guinea-pig brain P2 membranes. Several researchers have reported high densities of both sigma receptor subtypes in guinea-pig and rat liver tissues $[6,16,52]$. Representative $B_{\max }$ values determined for $\sigma 1$ and $\sigma 2$ in rat brain $\mathrm{P} 2$ are $\sim 300-500 \mathrm{fmol} / \mathrm{mg}$ and $\sim 1000 \mathrm{fmol} / \mathrm{mg}$, respectively $[81,82]$, while representative $\mathrm{B}_{\max }$ values determined for $\sigma 1$ and $\sigma 2$ in rat liver $\mathrm{P} 2$ are approximately $3 \mathrm{pmol} / \mathrm{mg}$ and $9 \mathrm{pmol} / \mathrm{mg}$, respectively [6]. The six to ten-fold higher density of $\sigma 1$ receptors in rat liver, relative to rat brain, is expected to facilitate the use of high throughput radioligand binding methods with the constraints imposed by conditions required to prevent radioligand depletion and sample size limitations imposed by the higher throughput formats. Reports on rigorous direct comparisons of binding of $\sigma 1$ ligands in isolates from rat brain versus rat liver labeled with $\left[{ }^{3} \mathrm{H}\right](+)$-pentazocine support the pharmacological equivalency of receptors derived from the two tissues $[16,59,83]$. Most contemporary binding studies for $\sigma 2$ already employ rat liver P2 membranes so no change of receptor source is required for adapting $\sigma 2$ assays to the higher throughput methods [43, 80, 84-88]. 


\section{7. $\mathrm{Ca}^{2+}$ and ligand sensitive interaction of $\sigma 1$ with binding immunoglobulin}

Binding immunoglobulin protein (BiP/GRP78) is a $\mathrm{Ca}^{2+}$ binding ER chaperone that functions as an $\mathrm{ER} \mathrm{Ca}^{2+}$ buffer, modulates the unfolded protein response (UPR), and aids in protein folding $[89,90]$. In 2007 Hayashi and $\mathrm{Su}[91]$ reported that the interaction of $\sigma 1$ with $\mathrm{BiP}$ regulates $\mathrm{Ca}^{2+}$ signaling between the ER and mitochondria via $\mathrm{IP}_{3}$ receptors localized at focal points called the mitochondrial associated membrane (MAM). Evidence for a $\sigma 1 /$ BiP complex was obtained from wild-type $\mathrm{CHO}$ (Chinese hamster ovary) cells by co-immunoprecipitation of a $\sigma 1 / \mathrm{BiP}$ complex using anti-bodies for either protein [91]. This complex was found with or without chemical crosslinking prior to cell lysis, suggesting that the interaction occurs endogenously and is not an isolation artifact [91]. The sensitivity of the $\sigma 1 / \mathrm{BiP}$ protein complex to sigma agonists and $\mathrm{Ca}^{2+}$ was unequivocally demonstrated in isolates from CHO cells expressing ol-EYFP (enhanced yellow fluorescent protein) [91]. Co-immunoprecipitation studies with crude cell lysates from CHO cells expressing $\sigma 1$-EYFP exposed in situ to $\sigma 1$ agonists, showed a dose-dependent decrease in co-precipitated BiP protein following immunoprecipitation with an anti-EYFP linked sepharose affinity matrix [91]. Application of $\sigma 1$ antagonists in this system prevented the action of agonists but had little effect or slightly promoted formation of the complex when they were administered alone [91].

\subsection{Alphascreen technology}

Alphascreen is a well developed assay technology marketed by Perkin Elmer (Waltham, MA) with proven applications in the detection of low to high affinity protein interactions in samples of purified recombinant, membrane bound, and solubilized proteins from cells and tissues [92, 93]. The basis for the Alphascreen is the generation of a luminescent signal when the "donor" and "acceptor" beads are brought into close proximity by association of proteins captured on the respective beads $[92,93]$. This general property can be exploited in both signal increasing and signal decreasing assays, which are well represented by kits available from Perkin Elmer for assaying interactions as diverse as receptor/ligand interactions, kinase and protease assays and ELISA-type immunoassays [92, 93]. A recently described assay of inhibitors of the interaction of heat shock protein 90 (Hsp90) and its co-chaperone, heat shock organizing protein (HOP), demonstrates the successful application of this technology in the analysis of small molecule inhibitors of a protein-protein interaction [94, 95]. Some advantages of the Alphascreen 
technology include, 1) numerous available bead chemistries, permitting the detection of diverse protein interactions with flexible assay design options, 2) high sensitivity with low signal to background ratio, and 3) adaptability to miniaturization and high throughput screening (HTS).

\subsection{Applications for high throughput methods in sigma receptor research}

In addition to routine analysis of putative novel sigma ligands, high throughput binding and functional assays for $\sigma 1$ receptors may be suitable for screening compound libraries such as the Prestwick Chemical Library (Washington, DC), a library composed of 1200 FDA-approved (U.S. Food and Drug Administration) small molecule drugs with high chemical and pharmacological diversity. The results could identify new compounds, or structural or pharmacological classes of compounds whose therapeutic activity may be due, in part, to interaction with $\sigma 1$ receptors. Antidepressants are an example of a druggable pharmacological class with varying chemical structures that demonstrate affinity for the sigma receptor [96]. The availability of a medium or high throughput functional assay would also facilitate tests for correlation between binding affinity and functional activity for these and other classes of current and future therapeutics.

\subsection{Summary}

Radioligand binding approaches remain an essential component for the discovery and development of novel sigma receptor ligands that have potential use as therapeutics and as imaging probes. New novel radiolabeled probes and advances in high throughput radioligand binding technologies provide an opportunity to significantly improve performance standards for this critical phase of drug discovery. The successful development of an in vitro functional assay for the $\sigma 1$ receptor would bring a powerful analytical tool that is not currently available to sigma receptor research. New capabilities enjoyed as a result of these efforts are anticipated to aid in the discovery and design of future drug development candidates as well as provide further insight into the structure and function of the $\sigma 1$ receptor subtype. 


\subsection{Research objectives}

The objective of these studies was to develop new in vitro tools to examine the binding and functional activity of sigma ligands by addressing the following specific aims:

\section{$\operatorname{Aim} I$}

Demonstrate the suitability of $\left[{ }^{3} \mathrm{H}\right] \mathrm{SN} 56$ for use in conventional radioligand binding assays.

\section{Aim II}

Develop medium throughput assays for the determination of binding affinities of novel $\sigma$ ligands.

\section{Aim III \\ Perform preliminary studies to support the development of a high throughput in vitro functional assay for $\sigma 1$ ligands based on the agonist sensitive interaction between $\sigma 1$ and BiP.}




\subsection{References}

1. Martin, W.R., et al., The effects of morphine- and nalorphine- like drugs in the nondependent and morphine-dependent chronic spinal dog. J Pharmacol Exp Ther, 1976. 197(3): p. 517-32.

2. Tam, S.W., Naloxone-inaccessible sigma receptor in rat central nervous system. Proc Natl Acad Sci U S A, 1983. 80(21): p. 6703-7.

3. Su, T.P., Evidence for sigma opioid receptor: binding of [3H]SKF-10047 to etorphineinaccessible sites in guinea-pig brain. J Pharmacol Exp Ther, 1982. 223(2): p. 284-90.

4. Wolfe, S.A., Jr., S.G. Culp, and E.B. De Souza, Sigma-receptors in endocrine organs: identification, characterization, and autoradiographic localization in rat pituitary, adrenal, testis, and ovary. Endocrinology, 1989. 124(3): p. 1160-72.

5. Harada, Y., H. Hara, and T. Sukamoto, Characterization of specific (+)- $[3 H] N-$ allylnormetazocine and [3H]1,3-di(2-tolyl)guanidine binding sites in porcine gastric fundic mucosa. J Pharmacol Exp Ther, 1994. 269(3): p. 905-10.

6. Hellewell, S.B., et al., Rat liver and kidney contain high densities of sigma 1 and sigma 2 receptors: characterization by ligand binding and photoaffinity labeling. Eur $\mathrm{J}$ Pharmacol, 1994. 268(1): p. 9-18.

7. Novakova, M., et al., Inotropic action of sigma receptor ligands in isolated cardiac myocytes from adult rats. Eur J Pharmacol, 1995. 286(1): p. 19-30.

8. Wolfe, S.A., Jr., et al., Differential localization of three distinct binding sites for sigma receptor ligands in rat spleen. 1997. 72(1): p. 45-58.

9. Itzhak, Y., J.M. Hiller, and E.J. Simon, Characterization of specific binding sites for [3H](d)-N-allylnormetazocine in rat brain membranes. 1985. 27(1): p. 46-52.

10. Alonso, G., et al., Immunocytochemical localization of the sigma(1) receptor in the adult rat central nervous system. 2000. 97(1): p. 155-170. 
11. McCann, D.J., A.D. Weissman, and T.P. Su, Sigma-1 and sigma-2 sites in rat brain: comparison of regional, ontogenetic, and subcellular patterns. Synapse, 1994. 17(3): p. 182-9.

12. Hellewell, S.B. and W.D. Bowen, A sigma-like binding site in rat pheochromocytoma (PC12) cells: decreased affinity for (+)-benzomorphans and lower molecular weight suggest a different sigma receptor form from that of guinea pig brain. Brain Res, 1990. 527(2): p. 244-53.

13. Torrence-Campbell, C. and W.D. Bowen, Differential solubilization of rat liver sigma 1 and sigma 2 receptors: retention of sigma 2 sites in particulate fractions. Eur $\mathbf{J}$ Pharmacol, 1996. 304(1-3): p. 201-10.

14. Itzhak, Y., et al., Binding of sigma-ligands to C57BL/6 mouse brain membranes: effects of monoamine oxidase inhibitors and subcellular distribution studies suggest the existence of sigma-receptor subtypes. J Pharmacol Exp Ther, 1991. 257(1): p. 141-8.

15. Quirion, R., et al., A proposal for the classification of sigma binding sites. Trends Pharmacol Sci, 1992. 13(3): p. 85-6.

16. Hanner, M., et al., Purification, molecular cloning, and expression of the mammalian sigmal-binding site. Proc Natl Acad Sci U S A, 1996. 93(15): p. 8072-7.

17. Kekuda, R., et al., Cloning and functional expression of the human type 1 sigma receptor (hSigmaR1). Biochem Biophys Res Commun, 1996. 229(2): p. 553-8.

18. Seth, P., F.H. Leibach, and V. Ganapathy, Cloning and structural analysis of the cDNA and the gene encoding the murine type 1 sigma receptor. Biochem Biophys Res Commun, 1997. 241(2): p. 535-40.

19. Seth, P., et al., Cloning and functional characterization of a sigma receptor from rat brain. J Neurochem, 1998. 70(3): p. 922-31.

20. Mei, J. and G.W. Pasternak, Molecular cloning and pharmacological characterization of the rat sigmal receptor. Biochem Pharmacol, 2001. 62(3): p. 349-55. 
21. Maurice, T. and T.P. Su, The pharmacology of sigma-1 receptors. Pharmacol Ther, 2009.

22. Morin-Surun, M.P., et al., Intracellular sigmal receptor modulates phospholipase $C$ and protein kinase C activities in the brainstem. Proc Natl Acad Sci U S A, 1999. 96(14): p. 8196-9.

23. Hayashi, T. and T.P. Su, Intracellular dynamics of sigma-1 receptors (sigma(1) binding sites) in NG108-15 cells. 2003. 306(2): p. 726-733.

24. Mavlyutov, T.A. and A.E. Ruoho, Ligand-dependent localization and intracellular stability of sigma-1 receptors in CHO-K1 cells. 2007. 2: p. 8.

25. Tchedre, K.T., et al., Sigma-1 receptor regulation of voltage-gated calcium channels involves a direct interaction. Invest Ophthalmol Vis Sci, 2008. 49(11): p. 4993-5002.

26. Zhang, H. and J. Cuevas, sigma Receptor activation blocks potassium channels and depresses neuroexcitability in rat intracardiac neurons. J Pharmacol Exp Ther, 2005. 313(3): p. 1387-96.

27. Martina, M., et al., The sigma-1 receptor modulates NMDA receptor synaptic transmission and plasticity via SK channels in rat hippocampus. J Physiol, 2007. 578(Pt 1): p. 143-57.

28. Lupardus, P.J., et al., Membrane-delimited coupling between sigma receptors and $\mathrm{K}+$ channels in rat neurohypophysial terminals requires neither G-protein nor ATP. J Physiol, 2000. 526 Pt 3: p. 527-39.

29. Aydar, E., et al., The sigma receptor as a ligand-regulated auxiliary potassium channel subunit. Neuron, 2002. 34(3): p. 399-410.

30. Johannessen, M., et al., Voltage-gated sodium channel modulation by sigma-receptors in cardiac myocytes and heterologous systems. Am J Physiol Cell Physiol, 2009. 296(5): p. C1049-57. 
31. Novakova, M., et al., Highly selective sigma receptor ligands elevate inositol 1,4,5trisphosphate production in rat cardiac myocytes. Eur J Pharmacol, 1998. 353(2-3): p. 315-27.

32. Hayashi, T., T. Maurice, and T.P. Su, Ca(2+) signaling via sigma(1)-receptors: novel regulatory mechanism affecting intracellular Ca(2+) concentration. J Pharmacol Exp Ther, 2000. 293(3): p. 788-798.

33. Hayashi, T. and T.P. Su, Regulating ankyrin dynamics: Roles of sigma-1 receptors. Proc Natl Acad Sci U S A, 2001. 98(2): p. 491-496.

34. Hayashi, T. and T.P. Su, Sigma-1 receptor chaperones at the ER-mitochondrion interface regulate Ca(2+) signaling and cell survival. 2007. 131(3): p. 596-610.

35. Wu, Z. and W.D. Bowen, Role of sigma-1 receptor $C$-terminal segment in inositol 1,4,5trisphosphate receptor activation: constitutive enhancement of calcium signaling in MCF-7 tumor cells. J Biol Chem, 2008. 283(42): p. 28198-215.

36. Ramachandran, S., et al., The sigmal receptor interacts with $N$-alkyl amines and endogenous sphingolipids. Eur J Pharmacol, 2009. 609(1-3): p. 19-26.

37. Fontanilla, D., et al., The hallucinogen N,N-dimethyltryptamine (DMT) is an endogenous sigma-1 receptor regulator. Science, 2009. 323(5916): p. 934-7.

38. Su, T.P., E.D. London, and J.H. Jaffe, Steroid binding at sigma receptors suggests a link between endocrine, nervous, and immune systems. Science, 1988. 240(4849): p. 219-21.

39. Gebreselassie, D. and W.D. Bowen, Sigma-2 receptors are specifically localized to lipid rafts in rat liver membranes. 2004. 493(1-3): p. 19-28.

40. Colabufo, N.A., et al., Is the sigma2 receptor a histone binding protein? J Med Chem, 2006. 49(14): p. 4153-8. 
41. Mesangeau, C., et al., Conversion of a highly selective sigma-1 receptor-ligand to sigma2 receptor preferring ligands with anticocaine activity. J Med Chem, 2008. 51(5): p. $1482-6$.

42. Azzariti, A., et al., Cyclohexylpiperazine derivative PB28, a sigma2 agonist and sigma1 antagonist receptor, inhibits cell growth, modulates P-glycoprotein, and synergizes with anthracyclines in breast cancer. Mol Cancer Ther, 2006. 5(7): p. 1807-16.

43. Abate, C., et al., A structure-affinity and comparative molecular field analysis of sigma-2 (sigma2) receptor ligands. Cent Nerv Syst Agents Med Chem, 2009. 9(3): p. 246-57.

44. Cassano, G., et al., F281, synthetic agonist of the sigma-2 receptor, induces Ca2+ efflux from the endoplasmic reticulum and mitochondria in SK-N-SH cells. Cell Calcium, 2009. 45(4): p. 340-5.

45. Crawford, K.W. and W.D. Bowen, Sigma-2 receptor agonists activate a novel apoptotic pathway and potentiate antineoplastic drugs in breast tumor cell lines. Cancer Res, 2002. 62(1): p. 313-22.

46. van Waarde, A., et al., Sigma receptors in oncology: therapeutic and diagnostic applications of sigma ligands. Curr Pharm Des, 2010. 16(31): p. 3519-37.

47. Tu, Z., et al., Radiosynthesis and biological evaluation of a promising sigma(2)-receptor ligand radiolabeled with fluorine-18 or iodine-125 as a PET/SPECT probe for imaging breast cancer. Appl Radiat Isot, 2010. 68(12): p. 2268-73.

48. Mach, R.H. and K.T. Wheeler, Development of molecular probes for imaging sigma-2 receptors in vitro and in vivo. Cent Nerv Syst Agents Med Chem, 2009. 9(3): p. 230-45.

49. Abate, C., et al., Analogues of sigma Receptor Ligand 1-Cyclohexyl-4-[3-(5-methoxy1,2,3,4-tetrahydronaphthalen-1-yl)propyl]pipe razine (PB28) with Added Polar Functionality and Reduced Lipophilicity for Potential Use as Positron Emission Tomography Radiotracers. J Med Chem, 2011. 54(4): p. 1022-32. 
50. Walker, J.M., et al., Autoradiographic distribution of $[3 H](+)$-pentazocine and [3H]1,3di-o-tolylguanidine (DTG) binding sites in guinea pig brain: a comparative study. Brain Res, 1992. 581(1): p. 33-8.

51. Gundlach, A.L., B.L. Largent, and S.H. Snyder, Autoradiographic localization of sigma receptor binding sites in guinea pig and rat central nervous system with (+)3H-3-(3hydroxyphenyl)-N-(1-propyl)piperidine. J Neurosci, 1986. 6(6): p. 1757-70.

52. DeHaven-Hudkins, D.L., et al., sigma recognition sites in brain and peripheral tissues. Characterization and effects of cytochrome P450 inhibitors. Biochem Pharmacol, 1994. 47(7): p. 1231-9.

53. Hashimoto, K. and K. Ishiwata, Sigma receptor ligands: possible application as therapeutic drugs and as radiopharmaceuticals. Curr Pharm Des, 2006. 12(30): p. 385776.

54. Ishikawa, M., et al., High occupancy of sigma-1 receptors in the human brain after single oral administration of fluvoxamine: a positron emission tomography study using [11C]SA4503. Biol Psychiatry, 2007. 62(8): p. 878-83.

55. Toyohara, J., M. Sakata, and K. Ishiwata, Imaging of sigmal receptors in the human brain using PET and [11C]SA4503. Cent Nerv Syst Agents Med Chem, 2009. 9(3): p. 190-6.

56. Anderson, C.J., Molecular imaging of cancer. J Nucl Med, 2007. 48(7): p. 30N, 43N.

57. de Costa, B.R., et al., Synthesis and evaluation of optically pure [3H]-(+)-pentazocine, a highly potent and selective radioligand for sigma receptors. FEBS Lett, 1989. 251(1-2): p. 53-8.

58. Bowen, W., de Costa, B.R., Hellewell, S.B., Walker, J.M., Rice, K.C., [3H]-(+)Pentazocine: a potent and highly selective benzomorphan-based probe for sigma-1 receptors. Mol Neuropharmacol, 1993. 3: p. 117-126. 
59. Klouz, A., et al., [3H]BHDP as a novel and selective ligand for sigmal receptors in liver mitochondria and brain synaptosomes of the rat. FEBS Lett, 2003. 553(1-2): p. 157-62.

60. Ishiwata, K., et al., Age-related changes of the binding of [3h]SA4503 to sigmal receptors in the rat brain. 2003. 17(1): p. 73-77.

61. Lever, J.R., et al., Sigmal and sigma2 receptor binding affinity and selectivity of SA4503 and fluoroethyl SA4503. 2006. 59(6): p. 350-358.

62. Karasawa, J., S. Takahashi, and K. Horikomi, Binding properties of [3H]MS-377, a novel sigma receptor ligand, to rat brain membranes. 2000. 400(1): p. 51-57.

63. Yous, S., et al., Novel 2(3H)-Benzothiazolones as highly potent and selective sigma-1 receptor ligands. Medicinal Chemistry Research, 2005. 14(3): p. 158-168.

64. Birzin, E.T. and S.P. Rohrer, High-throughput receptor-binding methods for somatostatin receptor 2. Anal Biochem, 2002. 307(1): p. 159-66.

65. Hayashi, S., et al., Novel non-peptide nociceptin/orphanin FQ receptor agonist, 1-[1-(1Methylcyclooctyl)-4-piperidinyl]-2-[(3R)-3-piperidinyl]-1H-benzimi dazole: design, synthesis, and structure-activity relationship of oral receptor occupancy in the brain for orally potent antianxiety drug. J Med Chem, 2009. 52(3): p. 610-25.

66. Hui, X., et al., A robust homogeneous binding assay for alpha4beta2 nicotinic acetylcholine receptor. Acta Pharmacol Sin, 2005. 26(10): p. 1175-80.

67. Carrick, T., et al., Development of a scintillation proximity assay binding method for the human 5-hydroxytryptamine 6 receptor using intact cells. Anal Biochem, 2008. 381(1): p. 27-32.

68. Glickman, J.F., A. Schmid, and S. Ferrand, Scintillation proximity assays in highthroughput screening. Assay Drug Dev Technol, 2008. 6(3): p. 433-55.

69. Wu, S. and B. Liu, Application of scintillation proximity assay in drug discovery. BioDrugs, 2005. 19(6): p. 383-92. 
70. Scintillation Proximity Assay Manual, Amersham Biosciences.

71. Shrikhande, A., et al., Fully automated radioligand binding filtration assay for membrane-bound receptors. Biotechniques, 2002. 33(4): p. 932-7.

72. Harms, A., et al., Development of a 5-hydroxytryptamine(2A) receptor binding assay for high throughput screening using 96-well microfilter plates. J Biomol Screen, 2000. 5(4): p. 269-78.

73. Udenfriend, S., L. Gerber, and N. Nelson, Scintillation proximity assay: A sensitive and continuous isotopic method for monitoring ligand/receptor and antigen/antibody interactions. Analytical Biochemistry, 1987. 161(2): p. 494-500.

74. Amersham Product Guide. 2005, General Electric Company.

75. Tu, Z., et al., Synthesis and in Vitro and in Vivo Evaluation of (18)F-Labeled Positron Emission Tomography (PET) Ligands for Imaging the Vesicular Acetylcholine Transporter. J Med Chem, 2009. 52(5): p. 1358-69.

76. Chu, W., et al., New N-substituted 9-azabicyclo[3.3.1]nonan-3alpha-yl phenylcarbamate analogs as sigma 2 receptor ligands: synthesis, in vitro characterization, and evaluation as PET imaging and chemosensitization agents. Bioorg Med Chem, 2009. 17(3): p. $1222-$ 31.

77. Vangveravong, S., et al., Synthesis of N-substituted 9-azabicyclo[3.3.1]nonan-3alpha-yl carbamate analogs as sigma2 receptor ligands. Bioorg Med Chem, 2006. 14(20): p. 6988-97.

78. $\mathrm{Xu}, \quad \mathrm{J} ., \quad$ et al., [3H]N-[4-(3,4-dihydro-6,7-dimethoxyisoquinolin-2(1H)-yl)butyl]-2methoxy-5 -methylbenzamide: a novel sigma-2 receptor probe. Eur J Pharmacol, 2005. 525(1-3): p. 8-17.

79. Schepmann, D., et al., Expression of sigma receptors of human urinary bladder tumor cells (RT-4 cells) and development of a competitive receptor binding assay for the 
determination of ligand affinity to human sigma(2) receptors. J Pharm Biomed Anal, 2011.

80. Maestrup, E.G., et al., Synthesis, pharmacological activity and structure affinity relationships of spirocyclic sigma(1) receptor ligands with a (2-fluoroethyl) residue in 3position. Bioorg Med Chem, 2011. 19(1): p. 393-405.

81. Matsumoto, R.R., et al., Rimcazole analogs attenuate the convulsive effects of cocaine: correlation with binding to sigma receptors rather than dopamine transporters. Neuropharmacology, 2001. 41(7): p. 878-86.

82. Nguyen, E.C., et al., Involvement of sigma (sigma) receptors in the acute actions of methamphetamine: receptor binding and behavioral studies. Neuropharmacology, 2005. 49(5): p. 638-45.

83. Klouz, A., et al., Evidence for sigma-1-like receptors in isolated rat liver mitochondrial membranes. Br J Pharmacol, 2002. 135(7): p. 1607-15.

84. Zampieri, D., et al., Synthesis, biological evaluation, and three-dimensional in silico pharmacophore model for sigma(1) receptor ligands based on a series of substituted benzo[d]oxazol-2(3H)-one derivatives. J Med Chem, 2009. 52(17): p. 5380-93.

85. Berardi, F., et al., 1-Cyclohexylpiperazine and 3,3-dimethylpiperidine derivatives as sigma-1 (sigma1) and sigma-2 (sigma2) receptor ligands: a review. Cent Nerv Syst Agents Med Chem, 2009. 9(3): p. 205-19.

86. Colabufo, N.A., et al., Tritium radiolabelling of PB28, a potent sigma-2 receptor ligand: pharmacokinetic and pharmacodynamic characterization. Bioorg Med Chem Lett, 2008. 18(6): p. 2183-7.

87. Mamolo, M.G., et al., Substituted benzylaminoalkylindoles with preference for the sigma2 binding site. Eur J Med Chem, 2008. 43(10): p. 2073-81. 
88. Hajipour, A.R., et al., Synthesis and characterization of N,N-dialkyl and N-alkyl-Naralkyl fenpropimorph-derived compounds as high affinity ligands for sigma receptors. Bioorg Med Chem, 2010. 18(12): p. 4397-404.

89. Quinones, Q.J., G.G. de Ridder, and S.V. Pizzo, GRP78: a chaperone with diverse roles beyond the endoplasmic reticulum. Histol Histopathol, 2008. 23(11): p. 1409-16.

90. Dudek, J., et al., Functions and pathologies of BiP and its interaction partners. Cell Mol Life Sci, 2009. 66(9): p. 1556-69.

91. Hayashi, T. and T.P. Su, Sigma-1 receptor chaperones at the ER-mitochondrion interface regulate Ca(2+) signaling and cell survival. Cell, 2007. 131(3): p. 596-610.

92. A Practical Guide to working with AlphaScreen. 2004, PerkinElmer, Inc.

93. AlphaLISA® Assay Development Guide, PerkinElmer Inc.

94. Yi, F. and L. Regan, A novel class of small molecule inhibitors of Hsp90. ACS Chem Biol, 2008. 3(10): p. 645-54.

95. Yi, F., et al., An AlphaScreen-based high-throughput screen to identify inhibitors of Hsp90-cochaperone interaction. J Biomol Screen, 2009. 14(3): p. 273-81.

96. Fishback, J.A., et al., Sigma receptors: potential targets for a new class of antidepressant drug. Pharmacol Ther, 2010. 127(3): p. 271-82. 


\section{CHAPTER 2}

\section{Synthesis and characterization of $\left[{ }^{3} \mathrm{H}\right] \mathrm{SN56}$, a novel radioligand for the $\sigma 1$ receptor}

The material in this chapter was published in part in the European Journal of Pharmacology as follows:

Synthesis and characterization of $\left[{ }^{3} \mathrm{H}\right]-\mathrm{SN} 56$, a novel radioligand for the $\sigma 1$ receptor. Fishback

JA, Mesangeau C, Poupaert JH, McCurdy CR, Matsumoto RR. Eur J Pharmacol 2011 Feb

25;653(1-3):1-7 


\subsection{Abstract}

The study of the binding characteristics of $\sigma$ ligands in vivo and in vitro requires radiolabeled probes with high affinity and selectivity. The radioligand presently used for in vitro studies of the o1 receptor, $\left[{ }^{3} \mathrm{H}\right](+)$-pentazocine, has significant limitations: it is difficult to synthesize, has limited chemical stability, and can be problematic to obtain. Evaluation of a series of novel 2(3H)-benzothiazolone compounds revealed SN56 to have subnanomolar and preferential affinity for the $\sigma 1$ subtype, relative to $\sigma 2$ and non-sigma, binding sites. The goal of this study was to characterize the binding of $\left[{ }^{3} \mathrm{H}\right] \mathrm{SN} 56$ to $\sigma 1$ receptors isolated from rat brain. Standard in vitro binding techniques were utilized to 1) determine the specificity and affinity of binding to $\sigma 1$ receptors, 2) confirm that $\left[{ }^{3} \mathrm{H}\right] \mathrm{SN} 56$ labels sites previously identified as $\sigma 1$ by comparing binding to sites labeled by $\left[{ }^{3} \mathrm{H}\right](+)$-pentazocine, and 3) characterize the kinetics of binding. The results indicate that $\left[{ }^{3} \mathrm{H}\right] \mathrm{SN} 56$ exhibits 1) specific, saturable, and reversible binding to the $\sigma 1$ receptor, with $\mathrm{B}_{\max }=340 \pm 10 \mathrm{fmol} / \mathrm{mg}$ and $\mathrm{K}_{\mathrm{d}}=0.069 \pm 0.007 \mathrm{nM}$, 2) competitive displacement by classical sigma compounds, yielding $\sigma 1 \mathrm{~K}_{\mathrm{i}}$ values consistent with those reported in the literature, and 3) binding kinetics compatible with a 90 min incubation, and filtration for separation of free and bound radioligand. The results of these studies suggest that $\left[{ }^{3} \mathrm{H}\right] \mathrm{SN} 56$ may serve as a viable alternative to $\left[{ }^{3} \mathrm{H}\right](+)$-pentazocine in radioligand binding assays. 


\subsection{Introduction}

The sigma receptor was first identified as an opioid receptor subtype based on behavioral studies of morphine-like drugs in dogs [1]. Subsequent in vitro binding data revealed that this site represents a new class of non-opioid receptor [2]. To date, two subtypes of sigma receptors $(\sigma 1$ and $\sigma 2$ ) have been identified based on differences in ligand selectivity, tissue distribution, and molecular characterization [3]. The $\sigma 1$ receptor has been cloned from multiple species [4-9] and a significant number of ligands with high affinity and selectivity for it are available. The $\sigma 2$ receptor is less well characterized; it has not been cloned, and few specific ligands have been described.

The $\sigma 1$ receptor is involved in numerous physiological processes and disease states, and in vivo and in vitro studies indicate that modulation of $\sigma 1$ receptors using sigma specific ligands can affect these systems [10-13]. Consequently, the $\sigma 1$ receptor is recognized as a potential medication development target and efforts to identify novel selective compounds are ongoing. While the $\sigma 2$ receptor may also represent a feasible drug development target, further research in this area will require the discovery of additional selective ligands for this subtype. The focus of the current work is therefore limited to the characterization of $\sigma 1$ binding.

DeCosta et al. [14] first described $\left[{ }^{3} \mathrm{H}\right](+)$-pentazocine, a highly selective radioprobe for $\sigma 1$ receptors. Subsequent studies demonstrated that $\left[{ }^{3} \mathrm{H}\right](+)$-pentazocine labeled a single class of sites in guinea-pig brain that correlated with the profile observed following labeling with the

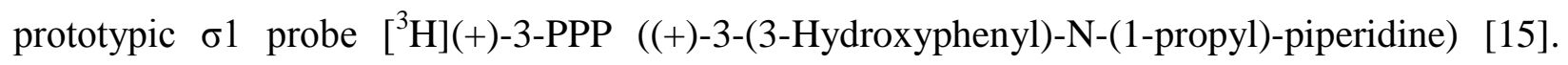
$\left[{ }^{3} \mathrm{H}\right](+)$-Pentazocine exhibited low levels of non-specific binding and high affinity for $\sigma 1$ receptors $\left(\mathrm{K}_{\mathrm{d}}=4.8 \pm 0.4 \mathrm{nM}\right)$, with $>700$-fold preference for the $\sigma 1$ over the $\sigma 2$ subtype [15]. $\left[{ }^{3} \mathrm{H}\right](+)-$ Pentazocine does, however, exhibit shortcomings, including poor chemical stability, which limits its usefulness in routine studies.

Efforts to design new $\sigma 1$ specific ligands have produced a limited number of radioprobes useful for exploring the pharmacology of the $\sigma 1$ receptor. Unfortunately, like $\left[{ }^{3} \mathrm{H}\right](+)$-pentazocine, each of the proposed new radioprobes exhibits limitations, such as slow association kinetics, marginal 
sigma subtype selectivity, or nanomolar affinity for other receptors. Therefore, we sought to characterize the performance of SN56 (3-(2-(azepan-1-yl)ethyl)-6-propylbenzo[d]thiazol-2(3H)one), a novel $\sigma 1$ selective, $2(3 \mathrm{H})$-benzothiazolone compound, as a tritiated radioligand, for use in $\sigma 1$ competition binding experiments. SN56 exhibited sub-nanomolar affinity $\left(\mathrm{K}_{\mathrm{i}} \sigma 1=0.56 \mathrm{nM}\right)$ and $>1,000$ fold selectivity for the $\sigma 1$ subtype relative to the $\sigma 2$ subtype in guinea-pig brain membranes, and at least 350-fold greater affinity for the $\sigma 1$ receptor versus a battery of receptors and transporters [16]. These binding characteristics coupled with a simple and economical synthetic scheme suggested $\left[{ }^{3} \mathrm{H}\right] \mathrm{SN} 56$ may provide a viable alternative to $\left[{ }^{3} \mathrm{H}\right](+)$-pentazocine in competition binding studies of the $\sigma 1$ receptor.

\subsection{Materials and Methods}

\subsubsection{Reagents and chemicals}

Reagents and starting materials for the synthesis of SN56 were obtained from commercial suppliers and were used without purification. Pre-coated silica gel GF Uniplates from Analtech (Newark, DE) were used for thin-layer chromatography (TLC). Column chromatography was performed on silica gel 60 (Sorbent Technologies, Atlanta, GA). 1H and 13C NMR spectra were obtained on a Bruker APX400 (Billerica, MA) at 400 and $100 \mathrm{MHz}$, respectively. High resolution mass spectra (HRMS) were recorded on a Waters Micromass Q-Tof Micro mass spectrometer with a lock spray source (Milford, MA). Mass spectra (MS) were recorded on a WATERS ACQUITY Ultra Performance LC (Milford, MA) with ZQ detector in ESI mode. Elemental analysis $(\mathrm{C}, \mathrm{H}, \mathrm{N})$ was performed on a Perkin-Elmer CHN/SO Series II Analyzer (Waltham, MA). Chemical names were generated using ChemDraw Ultra (CambridgeSoft, version 10.0, Cambridge, MA). $\left.{ }^{3} \mathrm{H}\right](+)$-Pentazocine $(29 \mathrm{Ci} / \mathrm{mmol})$ was purchased from Perkin Elmer (Boston, MS). (+)-SKF10,047 ((-)- $N$-allylnormetazocine hydrochloride), (+)-pentazocine, (-)-pentazocine, haloperidol, 1,3-di-o-tolylguanidine (DTG), bovine serum albumin (BSA)

fraction $\mathrm{V}$, sucrose, $\mathrm{NaCl}$, tris(hydroxymethyl)aminomethane (Tris), $1 \mathrm{~N}$ hydrochloric acid solution, and glacial acetic acid were purchased from Sigma-Aldrich (St. Louis, MO). Coomassie Protein Assay reagent, Ecoscint scintillation fluid and Brandel GF/B filter papers, 2.25 x 12.25 inches were purchased from Fisher Scientific (Pittsburgh, PA). 


\subsubsection{Synthesis of $\left[{ }^{3} \mathrm{H}\right] \mathrm{SN} 56$}

The design strategy for generating $\left[{ }^{3} \mathrm{H}\right] \mathrm{SN} 56$ involved replacing a bromine atom on the aromatic ring of SN56 with a tritium atom (Figure 1). The precursor compounds for the synthesis of $\left[{ }^{3} \mathrm{H}\right] \mathrm{SN} 56$, compounds 1, 2, 3 and $\mathbf{4}$ were synthesized by Christophe Mesangeau in the laboratory of Christopher McCurdy at the University of Mississippi. The preparation of the brominated precursor 4 is described below. Compounds 1 and $\mathbf{2}$ were prepared according to previously described procedures with minor modifications $[17,18]$. Selective bromination of the 6propylbenzo[d]thiazol-2(3H)-one 2 at the $\mathrm{C}-4$ position was effected with bromine in acetic acid at room temperature (RT). The bromo derivative was alkylated with 2-

(hexamethyleneimino)ethylchloride in the presence of potassium carbonate in dimethylformamide (DMF) to yield $\mathbf{4}$. Compound $\mathbf{4}$ was radiolabeled with tritium $(30 \mathrm{Ci} / \mathrm{mmol})$ by AmBios Labs, Inc. (Newington, CT).

\subsubsection{6-Propionylbenzo[d]thiazol-2(3H)-one (1)}

Dimethylformamide $(5.96 \mathrm{ml}, 76.73 \mathrm{mmol})$ was added slowly to aluminum chloride $(35.5 \mathrm{~g}$, $264.6 \mathrm{mmol}$ ) with vigorous stirring. After $15 \mathrm{~min}$, 2-hydroxybenzothiazole (5.4 g, $40 \mathrm{mmol}$ ) was added and the mixture was heated to $45{ }^{\circ} \mathrm{C}$. After $15 \mathrm{~min}$, propionyl chloride $(3.46 \mathrm{ml}, 39.7$ mmol) was added and the reaction mixture was heated to $85^{\circ} \mathrm{C}$ for $3 \mathrm{~h}$. The hot mixture was then poured on ice; the crude product was collected by filtration, and washed with water. The solid was dissolved in ethyl acetate and the solvent was washed with water and brine, dried and evaporated. The residue was recrystallized from toluene/dioxane (2/1) to give $2.96 \mathrm{~g} \mathrm{(54 \% )}$ of 6propionylbenzo[d]thiazol-2(3H)-one as a white solid. 1H NMR (DMSO-d6): $\delta 12.23$ (br s, 1H), 8.20 (s, 1H), 7.87 (d, J = 8.4 Hz, 1H), 7.17 (d, J = 8.3 Hz, 1H), 2.97 (q, J = 7.1 Hz, 2H), 1.06 (t, J $=7.1 \mathrm{~Hz}, 3 \mathrm{H}$ ). 13C NMR (DMSO-d6): $\delta$ 198.64, 170.46, 140.13, 131.21, 126.74, 123.69, 123.04, 111.17, 30.93, 8.22. MS (ESI) m/z 206 (M+-1).

\subsubsection{6-Propylbenzo[d]thiazol-2(3H)-one (2)}

Triethylsilane ( $4.75 \mathrm{ml}, 29.75 \mathrm{mmol})$ was added to a stirred solution of $\mathbf{1}(2.5 \mathrm{~g}, 12.06 \mathrm{mmol})$ in trifluoroacetic acid $(13 \mathrm{ml})$. The mixture was stirred vigorously for $2 \mathrm{~h}$ at RT. The trifluoroacetic acid was removed by evaporation and the residue was purified by chromatography on a silica gel column using petroleum ether/ethyl acetate $(9: 1)$ as the eluent to give $2.06 \mathrm{~g}(88 \%)$ of 6 - 
propylbenzo[d]thiazol-2(3H)-one as a white solid. 1H NMR (DMSO-d6): $\delta 11.76$ (br s, 1H), $7.33(\mathrm{~s}, 1 \mathrm{H}), 7.05(\mathrm{~d}, \mathrm{~J}=8.1 \mathrm{~Hz}, 1 \mathrm{H}), 6.99(\mathrm{~d}, \mathrm{~J}=8.1 \mathrm{~Hz}, 1 \mathrm{H}), 2.50$ (t, J = 7.4 Hz, 2H), 1.56-1.50 (m, 2H), 0.84 (t, J = 7.3 Hz, 3H). 13C NMR (DMSO-d6): $\delta$ 169.99, 136.68, 134.23, 126.57, 123.24, 122.12, 111.22, 36.87, 24.30, 13.54. MS (ESI) m/z 194 (M++1).

\subsubsection{4-Bromo-6-propylbenzo[d]thiazol-2(3H)-one (3)}

Bromine $(0.45 \mathrm{ml}, 8.75 \mathrm{mmol})$ was added slowly to a solution of $2(1.5 \mathrm{~g}, 7.76 \mathrm{mmol})$ in acetic acid $(10 \mathrm{ml})$. The mixture was stirred $15 \mathrm{~h}$ at RT, poured into water and extracted with ethyl acetate $(3 \times 30 \mathrm{ml})$. The combined organic layers were washed with a $10 \%$ solution of potassium carbonate followed by brine. The solution was dried over sodium sulfate and evaporated under vacuum. The residue was purified by chromatography on a silica gel column using petroleum ether/ethyl acetate (9:1) as the eluent to give $0.5 \mathrm{~g}(24 \%)$ of 4-bromo-6-propylbenzo[d]thiazol2(3H)-one as a white solid. 1H NMR (CDCl3): $\delta 9.29(\mathrm{~s}, 1 \mathrm{H}), 7.26(\mathrm{~s}, 1 \mathrm{H}), 7.12(\mathrm{~s}, 1 \mathrm{H}), 2.56(\mathrm{t}$, $\mathrm{J}=7.6 \mathrm{~Hz}, 2 \mathrm{H}), 1.62(\mathrm{~m}, 2 \mathrm{H}), 0.93$ (t, J = 7.2 Hz, 2H). 13C NMR (CDCl3): $\delta$ 170.45, 139.35, 132.22, 129.34, 124.44, 121.24, 103.90, 37.37, 24.48, 13.54. MS (ESI) m/z 270 (M+-1), 272 $(\mathrm{M}++1)$.

\subsubsection{3-(2-(Azepan-1-yl)ethyl)-4-bromo-6-propylbenzo[d]thiazol-2(3H)-one hydrochloride (4)}

$\mathrm{NaHCO}_{3}(0.51 \mathrm{~g}, 6.09 \mathrm{mmol})$ and 2-(hexamethyleneimino)ethylchloride hydrochloride $(0.80 \mathrm{~g}$, $4.06 \mathrm{mmol})$ were added, with mechanical stirring, to a solution of $\mathbf{3}(0.55 \mathrm{~g}, 2.03 \mathrm{mmol})$ in anhydrous DMF $(15 \mathrm{ml})$. The reaction mixture was heated to $80{ }^{\circ} \mathrm{C}$ for $1 \mathrm{~h}$. After cooling, the mixture was poured into $80 \mathrm{ml}$ of water, extracted with ethyl acetate $(3 \times 60 \mathrm{ml})$, and the combined organic layers were washed with brine and dried. The solvent was removed in vacuo, and the residue was chromatographed on a silica gel column using ethyl acetate/petroleum ether (4:6) as the eluent. 3-(2-(Azepan-1-yl)ethyl)-4-bromo-6-propylbenzo[d]thiazol-2(3H)-one was isolated as a hydrochloride salt (white solid, $0.44 \mathrm{~g}, 49 \%$ ) by addition of $\mathrm{HCl} /$ dioxane. 1H NMR (DMSO-d6): $\delta 10.81$ (br s, 1H), 7.60 (s, 1H), 7.46 (s, 1H), 4.72 (t, J = 7.2 Hz, 2H), 3.47-3.24 $(\mathrm{m}, 6 \mathrm{H}), 2.56(\mathrm{t}, \mathrm{J}=7.5 \mathrm{~Hz}, 2 \mathrm{H}), 1.86(\mathrm{br} \mathrm{s}, 4 \mathrm{H}), 1.67-1.55(\mathrm{~m}, 6 \mathrm{H}), 0.88$ (t, J = 7.2 Hz, 3H). 13C NMR (DMSO-d6): $\delta$ 170.54, 138.87, 132.87, 132.63, 125.62, 121.79, 103.79, 56.73, 55.89, 43.14, 37.04, 28.58, 27.22, 24.51, 13.81. Analysis calculated for C18H26 BrCIN2OS: C, 49.83; H, 6.04; N, 6.46. Found: C, 50.06; H, 5.93; N, 6.47. HRMS calculated for C18H26N2OSBr 
$[\mathrm{M}+\mathrm{H}]+397.0949$, found 397.0945. A synopsis of the synthetic route of the synthesis of the brominated $\left[{ }^{3} \mathrm{H}\right]-\mathrm{SN} 56$ precursor is provided in Figure 2.

\subsubsection{Membrane preparation}

Crude P2 rat brain homogenates were prepared from male, Sprague Dawley rats (150-200 g) purchased from Harlan (Indianapolis, IN) as described previously [19]. All procedures involving live animals were performed as approved by the Institutional Animal Care and Use Committee at the locations where the assays were performed. Briefly, unanesthetized rats were sacrificed by decapitation; brains minus cerebellum were harvested and maintained in ice cold $10 \mathrm{mM}$ Tris/ $0.9 \% \mathrm{NaCl}$ until processed. Tissues were homogenized with a Potter-Elvehjem homogenizer (5-10 strokes with motor driven Teflon pestle) in ice-cold $10 \mathrm{mM}$ Tris-sucrose buffer (0.32 $\mathrm{M}$ sucrose in $10 \mathrm{mM}$ Tris, $\mathrm{pH}$ 7.4) using $10 \mathrm{ml}$ buffer per $\mathrm{g}$ of tissue $\mathrm{x} \sim 3 \mathrm{~g}$ tissue/batch. Homogenates from multiple batches were combined and centrifuged for $10 \mathrm{~min}$ at 1,000 x g, at 4 ${ }^{\circ} \mathrm{C}$. Supernatants were decanted, combined and centrifuged for $15 \mathrm{~min}$ at $31,000 \mathrm{x} \mathrm{g}$, at $4{ }^{\circ} \mathrm{C}$. The material from centrifugation at 31,000 x g was washed as follows: 1) pellets were re-suspended in $10 \mathrm{mM}$ Tris, pH 7.4 using $3 \mathrm{ml}$ buffer per gram of tissue, 2) the resulting suspension was incubated for $30 \mathrm{~min}$ at $25^{\circ} \mathrm{C}, 3$ ) the resulting suspension was centrifuged for $15 \mathrm{~min}$ at $31,000 \mathrm{x}$ $\mathrm{g}$, at $4{ }^{\circ} \mathrm{C}$. The resulting pellets were re-suspended in Tris, $\mathrm{pH} 7.4$ buffer at a final concentration of $1 \mathrm{~g}$ of tissue per $1.53 \mathrm{ml}$ buffer. Tissue preparations were aliquoted in $1 \mathrm{ml}$ portions and stored at $-80^{\circ} \mathrm{C}$. The Bradford assay was used to quantitate protein concentration [20].

\subsubsection{Radioligand binding assays}

Initial optimization of assay conditions was performed to maximize total binding and minimize non-specific binding. Parameters examined included evaluation of the buffer composition and

$\mathrm{pH}$, ratio of radioligand to membrane concentration, and determination of ligand and ligand concentration for defining non-specific binding. The following optimized conditions were used for subsequent studies reported below: $0.5 \mathrm{ml}$ final sample volume, 90 min sample incubation at $25^{\circ} \mathrm{C}$, Tris, $\mathrm{pH} 8.0$ (assay buffer), and $100 \mu \mathrm{M}$ haloperidol (to define non-specific binding). Assay termination was effected by vacuum filtration through glass fiber filters on a 24 position Brandel cell harvester. Prior to use, filters were presoaked for $30 \mathrm{~min}$ in $0.5 \%$ polyethyleneimine to reduce non-specific binding. Following the initial filtration step, filters were washed 3 times 
with $5 \mathrm{ml}$ ice-cold $10 \mathrm{mM}$ Tris, $\mathrm{pH} 8$. The conditions determined from the preliminary studies were consistent with those reported in the literature for the analysis of $\sigma 1$ receptor binding using $\left[{ }^{3} \mathrm{H}\right](+)$-pentazocine $[15,21,22]$. It should be noted that it was necessary to prepare $\left[{ }^{3} \mathrm{H}\right] \mathrm{SN} 56$ spiking solutions in $1 \mathrm{mM} \mathrm{HCl}$, to prevent non-specific binding of the radioligand to glass and plasticware, which was problematic with solutions prepared in the assay buffer. This requirement is not unprecedented and the small amount of acid has no impact on the final $\mathrm{pH}$ of the assay sample [23].

\subsubsection{Association and dissociation assays}

Association and dissociation studies were conducted to confirm that the binding kinetics of $\left[{ }^{3} \mathrm{H}\right] \mathrm{SN} 56$ were appropriate for a 1-2 $\mathrm{h}$ incubation and processing by filtration. Kinetic studies were performed with $0.8 \mathrm{nM}\left[{ }^{3} \mathrm{H}\right] \mathrm{SN} 56$ and $100 \mu \mathrm{g}$ membrane. For determination of association rates, samples were incubated for times ranging from $5 \mathrm{~min}$ to $2 \mathrm{~h}$ prior to filtration. For determination of dissociation rates, membranes were incubated for 120 min with $\left[{ }^{3} \mathrm{H}\right] \mathrm{SN} 56$ prior to the addition of $100 \mu \mathrm{M}$ (final concentration) haloperidol, followed by filtration at times ranging from $30 \mathrm{~min}$ to $4 \mathrm{~h}$ from the addition of haloperidol. The assays were performed in duplicate and repeated three times.

\subsubsection{Saturation binding assays}

For the determination of $\mathrm{K}_{\mathrm{d}}$ and $\mathrm{B}_{\max }$ by saturation binding, ten concentrations ranging from 0.01 to $0.8 \mathrm{nM}$ of $\left[{ }^{3} \mathrm{H}\right] \mathrm{SN} 56$ were tested per experiment with $100 \mu \mathrm{g}$ membrane per sample. Nonspecific binding was determined by the addition of haloperidol, at a final concentration of 100 $\mu \mathrm{M}$. Samples for the determination of total and non-specific binding for each experiment were run concurrently and filtered simultaneously.

\subsubsection{Competition binding assays}

For the determination of $\mathrm{K}_{\mathrm{i}}$ for established $\sigma$ ligands by competition binding, aliquots of membrane were incubated with $\left[{ }^{3} \mathrm{H}\right] \mathrm{SN} 56$ and varying concentrations of test ligands. The following test compounds were evaluated: 1,3-di-o-tolylguanidine (DTG), haloperidol, (+)pentazocine, (-)-pentazocine and (+)-SKF10,047. For each test compound, ten concentrations were incubated with $0.7-0.8 \mathrm{nM}\left[{ }^{3} \mathrm{H}\right] \mathrm{SN} 56$ with $100 \mu \mathrm{g}$ membrane per sample. Non-specific 
binding was determined by the addition of haloperidol, at a final concentration of $100 \mu \mathrm{M}$. Samples for the determination of total and non-specific binding for each experiment were run concurrently and filtered simultaneously.

\subsubsection{Scintillation counting and data analysis}

Following washing, filters were transferred to scintillation vials and $5 \mathrm{ml}$ scintillation cocktail was added. Filters were allowed to soak in cocktail for a minimum of $10 \mathrm{~h}$ prior to counting. The data were analyzed using GraphPad Prism software (San Diego, CA). Saturation binding data were fit using nonlinear regression to a one-site model. A Hill plot of the saturation data was generated by linear regression of the plot of $\log \left([\mathrm{B}] / \mathrm{B}_{\max }-[\mathrm{B}]\right)$ versus $\log [\mathrm{L}]$, where $[\mathrm{L}]=$ radioligand concentration, and $[\mathrm{B}]=$ the concentration of radioligand bound at the respective [L]. Association kinetics data were fit using linear regression of the plot of $\ln \left(B_{\mathrm{e}}-\mathrm{B} / \mathrm{B}_{\mathrm{e}}\right)$ versus time, where $\mathrm{B}_{\mathrm{e}}=$ radioligand bound at equilibrium, and $\mathrm{B}=$ radioligand bound at time $\mathrm{t}$; the slope of the plot yielded $\mathrm{k}^{\mathrm{obs}}$. The association rate constant $\left(\mathrm{k}^{+1}\right)$ was calculated using the pseudo firstorder method from the equation $\mathrm{k}^{+1}=\left(\mathrm{k}_{\mathrm{obs}}-\mathrm{k}^{-1}\right) /[\mathrm{L}]$. Dissociation kinetics data were fit using linear regression of the plot of $\ln \left(\mathrm{B} / \mathrm{B}_{0}\right)$ versus time, where $\mathrm{B}_{0}=$ specific radioligand bound at time of addition of haloperidol, and $\mathrm{B}=$ specific radioligand bound at time $\mathrm{t}$. For competition binding data, $\mathrm{K}_{\mathrm{i}}$ values were calculated from experimentally determined $\mathrm{IC}_{50}$ values with the Cheng-Prusoff equation using the $\mathrm{K}_{\mathrm{d}}$ for $\left[{ }^{3} \mathrm{H}\right] \mathrm{SN} 56$ determined from the saturation binding experiments $(0.069 \mathrm{nM})$. For comparison of competition binding data obtained with [ $\left.{ }^{3} \mathrm{H}\right] \mathrm{SN} 56$ to data obtained with $\left[{ }^{3} \mathrm{H}\right](+)$-pentazocine a correlation plot was generated with the assumption that data were sampled from Gaussian populations (Pearson r) using a two-tailed fit. 


\subsection{Results}

\subsubsection{Basic binding parameters}

At near saturating conditions, non-specific binding of $\left[{ }^{3} \mathrm{H}\right] \mathrm{SN} 56$ remained essentially constant in the presence of 25 to $200 \mu \mathrm{g}$ membrane, suggesting that the observed non-specific binding is due primarily to filter binding. As shown in Figure 3, total binding was linear from 50 to $200 \mu \mathrm{g}$ membrane.

\subsubsection{Association and dissociation kinetics}

From the association studies, $\mathrm{k}_{\mathrm{obs}}=0.080 \mathrm{~min}-1$ and $\mathrm{k}^{+1}=9.05 \times 10^{7} \mathrm{~min}^{-1} \mathrm{M}^{-1}$. From the dissociation studies, $\mathrm{k}^{-1}=0.0076 \mathrm{~min}-1$ and $\mathrm{t}_{1 / 2}=91 \mathrm{~min}$. The $\mathrm{K}_{\mathrm{d}}$ calculated from $\mathrm{k}^{-1} / \mathrm{k}^{+1}$ was $0.084 \mathrm{nM}$. The low dissociation rate permits the use of filtration for the separation of free from bound radioligand [24], while the association rate supports 90 min incubations for attaining steady-state binding.

\subsubsection{Saturation binding}

Figure 4 shows the results of the saturation binding study of $\left[{ }^{3} \mathrm{H}\right] \mathrm{SN} 56$. Non-linear analysis of the saturation binding data fitted using a one-site model yielded a $K_{d}=0.069 \pm 0.007 \mathrm{nM} \mathrm{nM}$ and a receptor density $\left(B_{\max }\right)$ of $340 \pm 10 \mathrm{fmol} / \mathrm{mg}\left(R^{2}=0.96\right)$. This represents a 70 -fold higher affinity than reported for $\left[{ }^{3} \mathrm{H}\right](+)$-pentazocine $\left(\mathrm{K}_{\mathrm{d}}=4.8 \mathrm{nM}\right)$ [15]. A Hill plot of the data yielded a slope $=1.14$ with $\mathrm{R}^{2}=0.96$. A two-site fit of the saturation data yielded a "did not converge" message from the Prism curve-fitting software, indicating the data does not fit a two-site binding model.

\subsubsection{Competition binding}

$\mathrm{K}_{\mathrm{i}}$ s determined in this study using $\left[{ }^{3} \mathrm{H}\right] \mathrm{SN} 56$ versus values determined using rat brain $\mathrm{P} 2$ with $\left[{ }^{3} \mathrm{H}\right](+)$-pentazocine, processed using Brandel filtration, determined in studies detailed in Chapter 4 of this dissertation, are shown in Table 1. In Figure 5, a comparison of binding profiles of the sites labeled by $\left[{ }^{3} \mathrm{H}\right] \mathrm{SN} 56$ versus $\left[{ }^{3} \mathrm{H}\right](+)$-pentazocine is shown in a correlation plot of $\mathrm{K}_{\mathrm{i}}$ values obtained in this study versus the values obtained with $\left[{ }^{3} \mathrm{H}\right](+)$-pentazocine. For the group of hallmark sigma ligands tested, there was a significant correlation between the affinities obtained 
using the novel versus conventional radioligand (Pearson $r=0.99$ ). Of particular note is the higher affinity of (+)-pentazocine as compared to (-)-pentazocine in the assays, a stereoselectivity pattern that is consistent with binding to $\sigma 1$ receptors.

\subsection{Discussion}

Characterization of a series of novel $2(3 \mathrm{H})$-benzothiazolone compounds in sigma receptor competition binding assays revealed SN56 (3-(2-(azepan-1-yl)ethyl)-6-propylbenzo[d]thiazol$2(3 \mathrm{H})$-one) to have subnanomolar affinity and $>1,000$-fold selectivity for the $\sigma 1$ subtype relative to $\sigma 2$ [16]. Binding of SN56 to non-sigma binding sites was tested with a battery of receptors and transporters including, adrenoceptor $\alpha 1$, adrenoceptor $\alpha 2$, adrenoceptor $\beta 1$, adrenoceptor $\beta 2$, histamine H1, histamine H2, mu opioid, delta opioid, kappa opioid, dopamine D1, dopamine D2, serotonin 5HT2a, serotonin 5HT3, and GABAA receptors; and dopamine and serotonin transporters [16]. Of the binding sites tested, only $\alpha 2$ and $\mathrm{H} 1$ showed affinities greater than $1 \mu \mathrm{M}$ ( $\mathrm{K}_{\mathrm{i}} \alpha 2=205 \mathrm{nM}$, and $\mathrm{K}_{\mathrm{i}} \mathrm{H} 1=311 \mathrm{nM}$ respectively) [16]; however, the affinity of SN56 for the $\sigma 1$ receptor is approximately 350-times higher than its affinity for either of these receptors, indicating a favorable selectivity profile for the development of a radioprobe for use in radioligand binding studies.

In the present study, $\left[{ }^{3} \mathrm{H}\right] \mathrm{SN} 56$ exhibited $>95 \%$ specific binding to $\sigma 1$ receptors in rat brain membranes at concentrations up to 10 times the $\mathrm{K}_{\mathrm{d}}$. However, non-specific binding of $\left[{ }^{3} \mathrm{H}\right] \mathrm{SN} 56$ to the glass fiber filters used to separate bound from free radioligand was $25-35 \%$ at 10 times the $\mathrm{K}_{\mathrm{d}}$ concentration, resulting in a final specific binding signal of $65-75 \%$ of total observed binding. $\left[{ }^{3} \mathrm{H}\right] \mathrm{SN} 56$ exhibited saturable and reversible binding to a single high affinity site in rat P2 membranes with a binding profile similar to that observed for $\left[{ }^{3} \mathrm{H}\right](+)$-pentazocine. The $B_{\max }$ observed for $\left[{ }^{3} \mathrm{H}\right] \mathrm{SN} 56(340 \pm 10 \mathrm{fmol} / \mathrm{mg})$ was consistent with the range of values reported in the literature for rat brain labeled with $\left[{ }^{3} \mathrm{H}\right] \mathrm{BHDP},\left[{ }^{3} \mathrm{H}\right] \mathrm{SA} 4503$, or $\left[{ }^{3} \mathrm{H}\right](+)$-pentazocine $[25,26]$. The Hill plot of the saturation binding data, which describes the fraction of receptor saturatation as of function of radioligand concentration, yielded a slope of 1.14, suggesting there was no cooperativity in binding of $\left[{ }^{3} \mathrm{H}\right] \mathrm{SN} 56$. In addition, the $\mathrm{K}_{\mathrm{i}}$ values of established sigma receptor ligands determined by competition binding versus $\left[{ }^{3} \mathrm{H}\right] \mathrm{SN} 56$ were consistent with those reported 
in the literature against the well established $\sigma 1$ radioligand $\left[{ }^{3} \mathrm{H}\right](+)$-pentazocine [15]. Furthermore, the association and dissociation kinetics of $\left[{ }^{3} \mathrm{H}\right] \mathrm{SN} 56$ were shown to be amenable to two hour incubations, and filtration for separation of free from receptor bound radioligand.

Yous et al. [16] reported a $\mathrm{K}_{\mathrm{i}}$ of $0.56 \mathrm{nM}$ for SN56 versus $\left[{ }^{3} \mathrm{H}\right](+)$-pentazocine in $\mathrm{P} 2$ membranes prepared from guinea-pig brain. Similarly, we obtained a $K_{i}$ of $0.38 \mathrm{nM}$ versus $\left[{ }^{3} \mathrm{H}\right](+)-$ pentazocine in $\mathrm{P} 2$ membranes prepared from rat brain (data not shown). These values are $\sim 5$ fold higher than the affinity determined with saturation and kinetic studies of $\left[{ }^{3} \mathrm{H}\right] \mathrm{SN} 56(\sim 0.07 \mathrm{nM}$ and $\sim 0.08 \mathrm{nM}$ respectively. We suspect that depletion of the non-labeled ligand results in an erroneously high value for the $\mathrm{K}_{\mathrm{i}}$ of SN56 as determined by competition binding.

While most researchers are familiar with radioligand depletion due to excessive receptor concentration, depletion of the unlabeled ligand occurs when the affinity of the unlabeled compound greatly exceeds the affinity of the labeled compound [27, 28]. Goldstein et al. [28] used computer modeling to derive estimates of the error in the determination of the $\mathrm{K}_{\mathrm{i}}$ of ligands exhibiting higher affinities than the radioligands utilized in their measurement; the authors projected that for an unlabeled ligand with a true affinity 100 times greater than the radioligand (as in our case), 10\% radioligand depletion would result in an experimentally determined $\mathrm{K}_{\mathrm{d}} \sim 6$ times higher than the true value. Thus, the $\sim 5$-fold difference between the affinity of SN56, as determined by competition binding, and the affinity of $\left[{ }^{3} \mathrm{H}\right] \mathrm{SN} 56$ determined with saturation and kinetic studies may be explained by this phenomena.

Systematic errors resulting from the use of high receptor concentrations may also contribute to errors in both the determination of $\mathrm{K}_{\mathrm{d}}$ from saturation and kinetic experiments, and in the determination of $\mathrm{K}_{\mathrm{i}} \mathrm{s}$ of unlabeled compounds. However, these errors are minimal, quantifiable, and in practice when $\left[{ }^{3} \mathrm{H}\right] \mathrm{SN} 56$ is used for competition binding assays of $\sigma 1$ ligands, our preliminary results suggest they have no impact on our $\mathrm{K}_{\mathrm{i}}$ determinations as compared to historical data for the compounds tested

Practical considerations dictated that we use relatively high receptor concentrations; this introduces systematic error that is quantifiable and within acceptable limits. When possible, 
experimental conditions for binding experiments should be chosen so that the receptor concentration is less than $10 \%$ of the $\mathrm{K}_{\mathrm{d}}$ of the radioligand to minimize radioligand depletion [27]. However, with a radioligand with subnanomolar affinity this would require multi-milliliter sample volumes. Our experiments required $100 \mu \mathrm{g}$ of tissue to obtain adequate signal for precise detection. We chose $0.5 \mathrm{ml}$ sample volumes because we intend to adapt this method to a higher throughput 96-well method where sample volumes are more limited than in test tube based binding determinations. To ensure that $>90 \%$ of added radioligand was "free" (unbound) in competition binding experiments run under these conditions we utilized high concentrations of $\left[{ }^{3} \mathrm{H}\right] \mathrm{SN} 56$. While these conditions are not ideal they are tolerated if required for detection and the error in values obtained with the method are known and within an acceptable range as determined by the researcher's requirements [29].

Carter et al. [29] examined the effects of assay miniaturization using the human muscarinic M3 receptor expressed in $\mathrm{CHO}$ (Chinese hamster ovary) cells. This cell line expressed the M3 receptor at $\sim 5 \mathrm{pmol} / \mathrm{mg}$, and the novel radioligand they tested, $\left[{ }^{3} \mathrm{H}\right] \mathrm{NMS}\left(1-\left[\mathrm{N}-\mathrm{methyl}-{ }^{3} \mathrm{H}\right]\right.$ scopolamine methyl chloride), had an affinity of $41 \mathrm{pM}$ [29]. In their saturation binding studies they varied receptor concentrations over a wide range, with membrane amounts from 5-50 $\mu \mathrm{g}$ in volumes from 50-1750 $\mu$, resulting in ratios of receptor concentration ([receptor])/ $\mathrm{K}_{\mathrm{d}}$ from 0.35 122 [29]. They found that as the volume was decreased or the amount of membrane was increased the calculated $K_{d}$ and $B_{\max }$ increased [29]. When no corrections were made for radioligand depletion, with [receptor] $/ \mathrm{K}_{\mathrm{d}}=0.35$ (the lowest ratio tested, corresponding to $5 \mu \mathrm{g}$ in $1750 \mu \mathrm{l})$ they calculated the $\mathrm{K}_{\mathrm{d}}$ to be approximately 2.4 times the "true" value and with [receptor] $/ \mathrm{K}_{\mathrm{d}}=12.2(5 \mu \mathrm{g}$ in $50 \mu \mathrm{l})$ they calculated the $\mathrm{K}_{\mathrm{d}}$ to be approximately 4.6 times the true value [29]. When the $K_{d} s$ were recalculated, taking into account radioligand depletion, the resulting values were 2.3 and 3.0 times the true value, respectively [29]. Therefore, practitioners should be aware that experimental conditions resulting in excessive radioligand depletion will yield an overestimate of the true $\mathrm{K}_{\mathrm{d}}$ even if depletion is accounted for.

The conditions chosen for our saturation studies utilized a [receptor] $/ \mathrm{K}_{\mathrm{i}}$ of $\sim 0.25$. No corrections were made for radioligand depletion because it was not possible to accurately assess what portion of non-specific binding was due to binding to membrane versus binding to filter. Based 
on Carter's work [29] we might expect our results to overestimate the $\mathrm{K}_{\mathrm{d}}$ of $\left[{ }^{3} \mathrm{H}\right] \mathrm{SN} 56$ by 3fold. Carter's studies [29] of competition binding utilizing conditions of excessive radioligand depletion did not model the conditions we utilized, with [receptor] $=\sim 0.1 \mathrm{nM}$ and concentration $\left[{ }^{3} \mathrm{H}\right] \mathrm{SN} 56=\sim 1.5$ times the $\mathrm{K}_{\mathrm{i}}$ of SN56, so direct comparisons of our competition binding data to their data are not possible. However, as stated previously, the $\mathrm{K}_{\mathrm{i}}$ values we derived for the sigma receptor ligands tested correlated well with values reported in the literature.

No significant difference in binding affinities was observed following labeling with $\left[{ }^{3} \mathrm{H}\right](+)$ pentazocine versus $\left[{ }^{3} \mathrm{H}\right] \mathrm{SN} 56$ for the ligands tested. A larger pool of compounds should be screened to confirm that this relationship is maintained. If compounds are identified that yield significantly different $\mathrm{K}_{\mathrm{i}} \mathrm{s}$ with $\left[{ }^{3} \mathrm{H}\right](+)$-pentazocine versus $\left[{ }^{3} \mathrm{H}\right] \mathrm{SN} 56$, such a result would suggest that $\sigma 1$ receptors support multiple binding modalities.

Future advances in the field of sigma receptor therapeutic development will require greater knowledge of the nature of the interaction of sigma receptors with ligands and protein binding partners. Additional tools needed to further this knowledge include new subtype-specific agonist and antagonist ligands, radioligands, and other affinity labels and probes. The development of other technologies, such as high throughput methods for the determination of binding affinities, and in vitro functional assays, will also hasten efforts to design and identify new selective sigma ligands with potential therapeutic value.

In conclusion, the results of our studies show that $\left[{ }^{3} \mathrm{H}\right] \mathrm{SN} 56$ possesses high affinity and selectivity for the $\sigma 1$ receptor, and appears to be a viable alternative for $\left[{ }^{3} \mathrm{H}\right](+)$-pentazocine in radioligand binding assays. $\left[{ }^{3} \mathrm{H}\right] \mathrm{SN} 56$ demonstrated saturable and reversible binding to a single high affinity site in rat brain membranes with a binding profile similar to that observed for $\left[{ }^{3} \mathrm{H}\right](+)$-pentazocine. Thus, $\left[{ }^{3} \mathrm{H}\right] \mathrm{SN} 56$ represents a valuable tool for the study of the $\sigma 1$ receptor and the development of $\sigma 1$ receptor based therapeutics. Additional studies of $\left[{ }^{3} \mathrm{H}\right]-\mathrm{SN} 56$ are warranted to confirm the results observed in this study and more fully characterize its interaction with the $\sigma 1$ receptor. Proposed additional studies include: 1) expanding the number of ligands tested in competition binding studies with direct comparisons to results obtained with $\left[{ }^{3} \mathrm{H}\right](+)$ - 
pentazocine, and 2) confirming that SN56 competitively inhibits the binding of $\left[{ }^{3} \mathrm{H}\right](+)$ pentazocine and that (+)-pentazocine competitively inhibits the binding of $\left[{ }^{3} \mathrm{H}\right]-\mathrm{SN} 56$. 

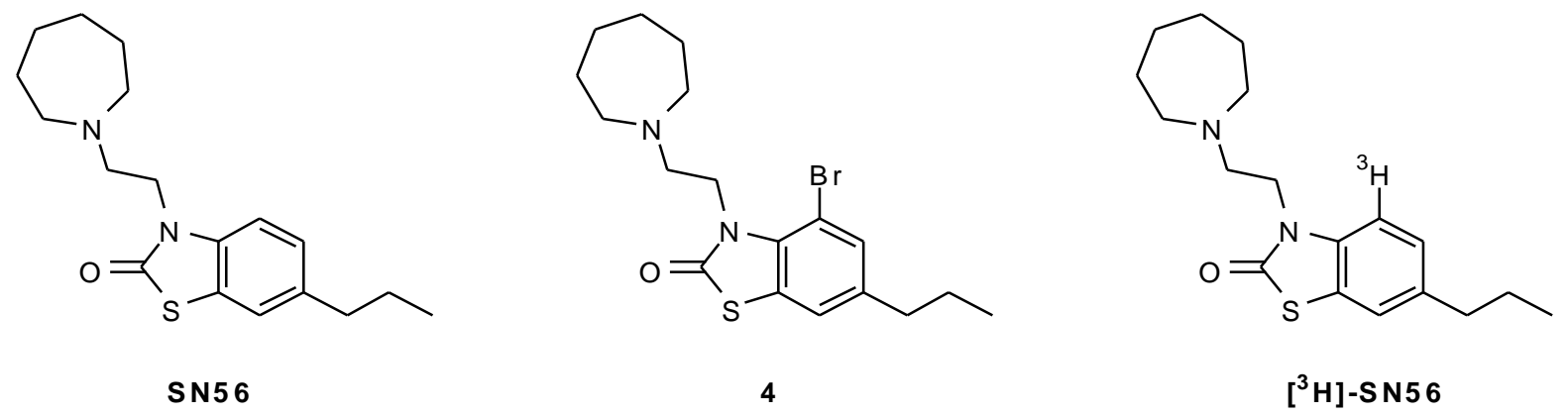

Figure 1. Structures of SN56, $\left[{ }^{3} \mathrm{H}\right] \mathrm{SN} 56$ and its bromo precursor 4. 
<smiles>O=c1[nH]c2ccccc2s1</smiles><smiles>CCC(=O)c1ccc2[nH]c(=O)sc2c1</smiles><smiles>CCCc1ccc2[nH]c(=O)sc2c1</smiles>
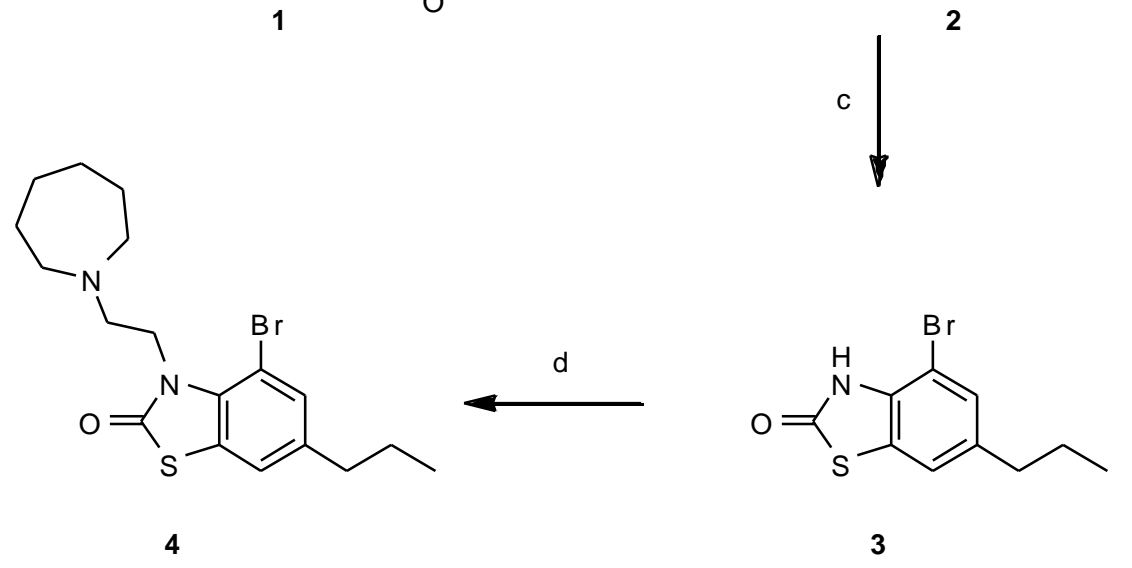

Figure 2. Synthesis of brominated $\left[{ }^{3} \mathrm{H}\right] \mathrm{SN} 56$ precursor 4 : a) Propionyl chloride, $\mathrm{AlCl}_{3}, 85{ }^{\circ} \mathrm{C}$; b) $\left(\mathrm{C}_{2} \mathrm{H}_{5}\right)_{3} \mathrm{SiH}, \mathrm{CF}_{3} \mathrm{COOH}, \mathrm{RT}$; c) $\mathrm{Br}_{2}, \mathrm{CH}_{3} \mathrm{COOH}, \mathrm{RT}$; d) 2-(hexamethyleneimino)ethylchloride hydrochloride, $\mathrm{K}_{2} \mathrm{CO}_{3}$, DMF, $80{ }^{\circ} \mathrm{C}$. 


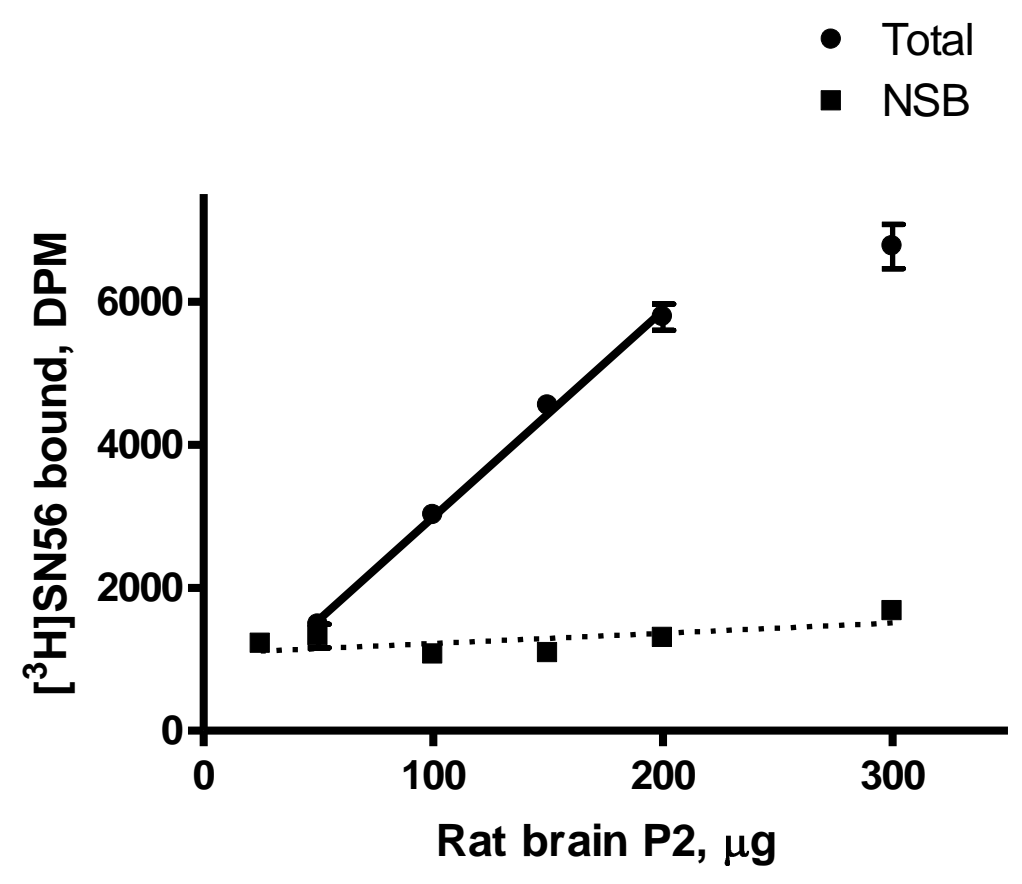

Figure 3. Binding linearity for $\left[{ }^{3} \mathrm{H}\right] \mathrm{SN} 56$ with rat brain P2 membranes. Samples contained 0.7 $\mathrm{nM}\left[{ }^{3} \mathrm{H}\right] \mathrm{SN} 56$, in a total volume of $0.5 \mathrm{ml}$. Non-specific binding (NSB) was determined by the addition of $100 \mu \mathrm{M}$ haloperidol. Data points represent the mean of three independent determinations of duplicate samples at each membrane concentration. The data point at $300 \mu \mathrm{g}$ rat brain P2 deviates from the linear binding observed from 50-200 $\mu \mathrm{g}$. 


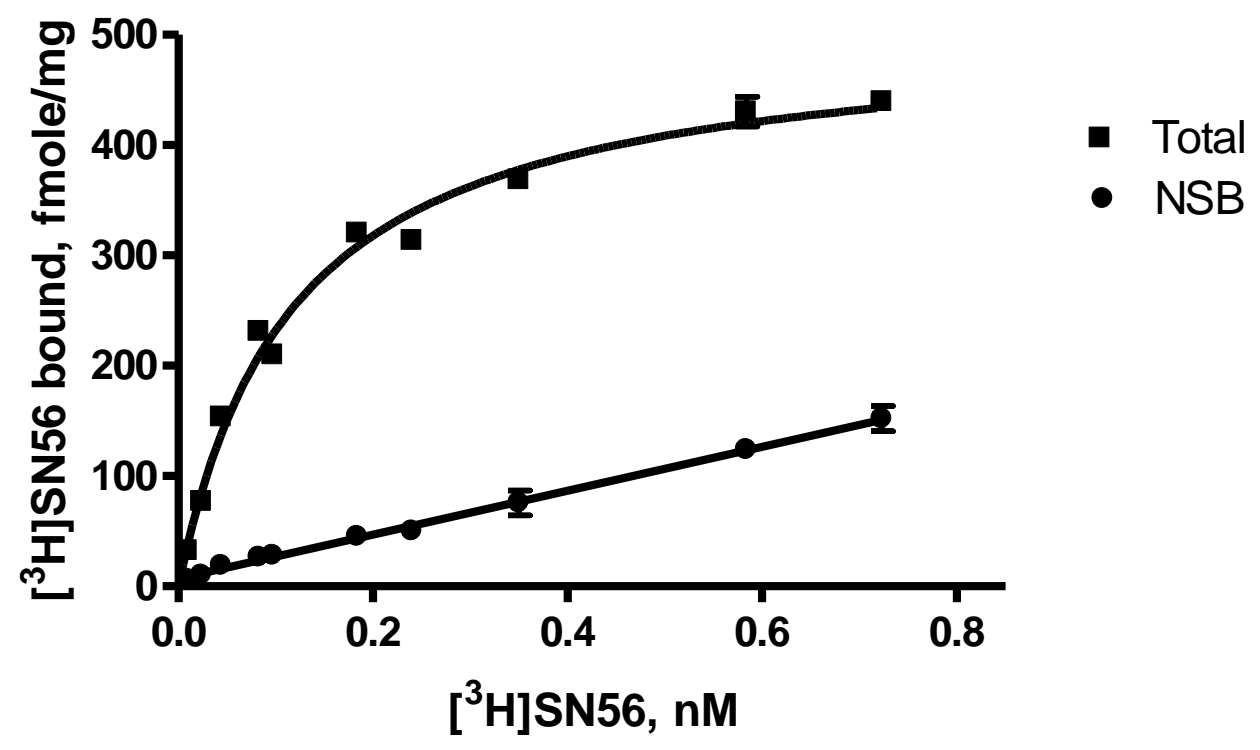

Figure 4. Saturation binding of $\left[{ }^{3} \mathrm{H}\right] \mathrm{SN} 56$ with rat brain P2 membranes. Samples contained 100 $\mu \mathrm{g}$ membrane in a total volume of $0.5 \mathrm{ml}$. Data points represent the mean $\pm \mathrm{SEM}$ of three independent determinations of duplicate samples at each concentration. $\mathrm{B}_{\max }=340 \pm 10$ $\mathrm{fmol} / \mathrm{mg}, \mathrm{K}_{\mathrm{d}}=0.069 \pm 0.007 \mathrm{nM}$. 
Table 1. Summary of data from competition binding experiments. The $\mathrm{K}_{\mathrm{i}}$ values determined with $\left[{ }^{3} \mathrm{H}\right](+)$-pentazocine were obtained using rat brain $\mathrm{P} 2$ processed by Brandel filtration as detailed in Chapter 4 of this dissertation.

\begin{tabular}{|l|c|c|}
\hline \multirow{2}{*}{ Compound } & \multicolumn{2}{|c|}{$\mathrm{K}_{\mathrm{i}}(\mathrm{nM})$} \\
\cline { 2 - 3 } & {$\left[{ }^{3} \mathrm{H}\right] \mathrm{SN} 56$} & {$\left[{ }^{3} \mathrm{H}\right](+)$-pentazocine } \\
\hline Haloperidol & $3.5 \pm 1.1$ & $3.9 \pm 0.5$ \\
\hline (+)-pentazocine & $5.7 \pm 1.0$ & $8.7 \pm 0.4$ \\
\hline (-)-pentazocine & $77.0 \pm 9.0$ & $57.2 \pm 1.9$ \\
\hline DTG & $41.6 \pm 8.8$ & $57.4 \pm 3.3$ \\
\hline (+)-SKF10,047 & $289 \pm 6$ & $287 \pm 36$ \\
\hline
\end{tabular}




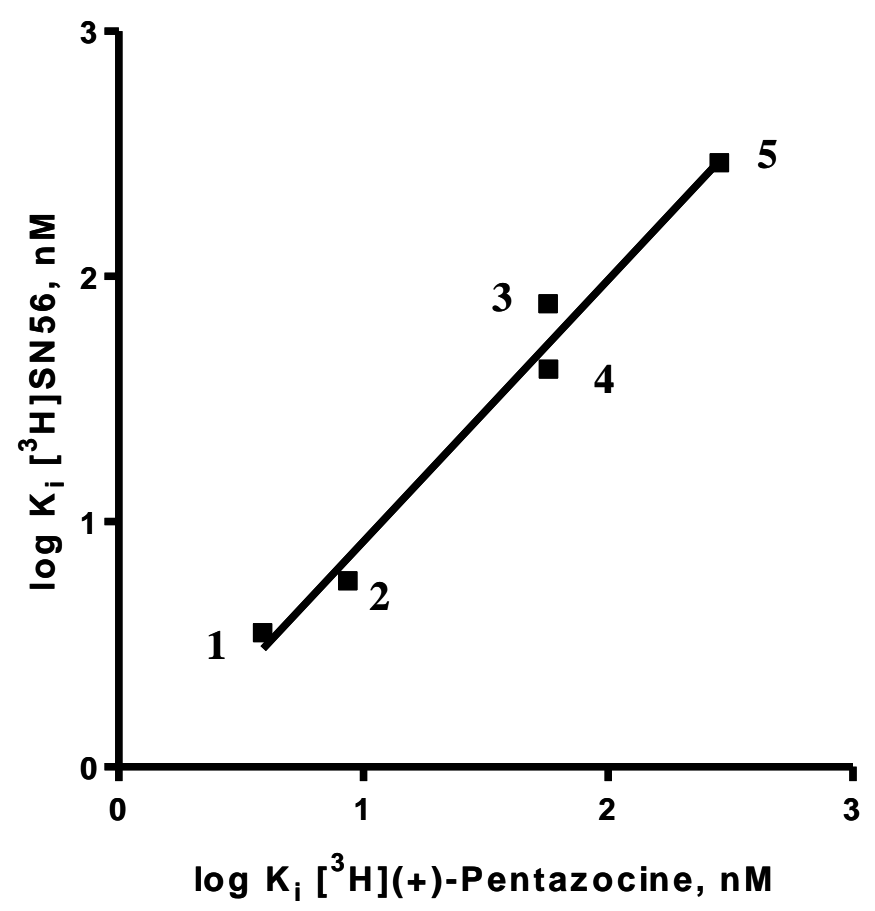

Figure 5. Comparison of $K_{i}$ values determined with $\left[{ }^{3} \mathrm{H}\right] \mathrm{SN} 56$ versus values determined with $\left[{ }^{3} \mathrm{H}\right](+)$-pentazocine as detailed in Chapter 4 of this dissertation. Pearson $r=0.99 .1$, haloperidol; 2, (+)-pentazocine; 3, (-)-pentazocine; 4, DTG; 5, (+)-SKF10,047. 


\subsection{References}

1. Martin, W.R., et al., The effects of morphine-and nalorphine- like drugs in the nondependent and morphine-dependent chronic spinal dog. J Pharmacol Exp Ther, 1976. 197(3): p. 517-32.

2. Tam, S.W., Naloxone-inaccessible sigma receptor in rat central nervous system. Proc Natl Acad Sci U S A, 1983. 80(21): p. 6703-7.

3. Quirion, R., et al., A proposal for the classification of sigma binding sites. Trends Pharmacol Sci, 1992. 13(3): p. 85-6.

4. Hanner, M., et al., Purification, molecular cloning, and expression of the mammalian sigmal-binding site. Proc Natl Acad Sci U S A, 1996. 93(15): p. 8072-7.

5. Kekuda, R., et al., Cloning and functional expression of the human type 1 sigma receptor (hSigmaR1). Biochem Biophys Res Commun, 1996. 229(2): p. 553-8.

6. Seth, P., F.H. Leibach, and V. Ganapathy, Cloning and structural analysis of the cDNA and the gene encoding the murine type 1 sigma receptor. Biochem Biophys Res Commun, 1997. 241(2): p. 535-40.

7. Mei, J. and G.W. Pasternak, Molecular cloning and pharmacological characterization of the rat sigmal receptor. Biochem Pharmacol, 2001. 62(3): p. 349-55.

8. Pan, Y.X., et al., Cloning and characterization of a mouse sigmal receptor. $\mathrm{J}$ Neurochem, 1998. 70(6): p. 2279-85.

9. Seth, P., et al., Cloning and functional characterization of a sigma receptor from rat brain. J Neurochem, 1998. 70(3): p. 922-31.

10. Maurice, T. and T.P. Su, The pharmacology of sigma-1 receptors. Pharmacol Ther, 2009. 124(2): p. 195-206. 
11. Cobos, E.J., et al., Pharmacology and therapeutic potential of sigma(1) receptor ligands. Curr Neuropharmacol, 2008. 6(4): p. 344-66.

12. Hashimoto, K. and K. Ishiwata, Sigma receptor ligands: possible application as therapeutic drugs and as radiopharmaceuticals. Curr Pharm Des, 2006. 12(30): p. 385776.

13. Guitart, X., X. Codony, and X. Monroy, Sigma receptors: biology and therapeutic potential. Psychopharmacology (Berl), 2004. 174(3): p. 301-19.

14. de Costa, B.R., et al., Synthesis and evaluation of optically pure [3H]-(+)-pentazocine, $a$ highly potent and selective radioligand for sigma receptors. FEBS Lett, 1989. 251(1-2): p. 53-8.

15. Bowen, W.D., et al., [3H]-(+)-Pentazocine: a potent and highly selective benzomorphanbased probe for sigma-1 receptors. Molecular Pharmacology, 1993. 1(3): p. 117-126.

16. Yous, S., et al., Novel 2(3H)-Benzothiazolones as highly potent and selective sigma-1 receptor ligands. Medicinal Chemistry Research, 2005. 14(3): p. 158-168.

17. Yous, S., et al., AlCl3-DMF Reagent in the Friedel-Crafts Reaction. Application to the Acylation Reaction of 2(3H)-Benzothiazolones. Journal of Organic Chemistry, 1994. 59: p. $1574-1576$.

18. Ucar, H., et al., Synthesis and anticonvulsant activity of 2(3H)-benzoxazolone and 2(3H)benzothiazolone derivatives. J Med Chem, 1998. 41(7): p. 1138-45.

19. Matsumoto, R.R., et al., Characterization of two novel sigma receptor ligands: antidystonic effects in rats suggest sigma receptor antagonism. Eur J Pharmacol, 1995. 280(3): p. 301-10.

20. Bradford, M.M., A rapid and sensitive method for the quantitation of microgram quantities of protein utilizing the principle of protein-dye binding. Anal Biochem, 1976. 72: p. $248-54$. 
21. Hellewell, S.B., et al., Rat liver and kidney contain high densities of sigma 1 and sigma 2 receptors: characterization by ligand binding and photoaffinity labeling. Eur J Pharmacol, 1994. 268(1): p. 9-18.

22. Matsumoto, R.R., et al., Dissociation of the motor effects of $(+)$-pentazocine from binding to sigma 1 sites. Eur J Pharmacol, 1996. 301(1-3): p. 31-40.

23. Bylund, D.B. and M.L. Toews, Radioligand binding methods: practical guide and tips. Am J Physiol, 1993. 265(5 Pt 1): p. L421-9.

24. Bylund, D.B., J.D. Deupree, and M.L. Toews, Radioligand-binding methods for membrane preparations and intact cells. Methods Mol Biol, 2004. 259: p. 1-28.

25. Klouz, A., et al., [3H]BHDP as a novel and selective ligand for sigmal receptors in liver mitochondria and brain synaptosomes of the rat. FEBS Lett, 2003. 553(1-2): p. 157-62.

26. Ishiwata, K., et al., Age-related changes of the binding of [3h]SA4503 to sigmal receptors in the rat brain. Ann Nucl Med, 2003. 17(1): p. 73-7.

27. Chang, K.J., S. Jacobs, and P. Cuatrecasas, Quantitative aspects of hormone-receptor interactions of high affinity. Effect of receptor concentration and measurement of dissociation constants of labeled and unlabeled hormones. Biochim Biophys Acta, 1975. 406(2): p. 294-303.

28. Goldstein, A. and R.W. Barrett, Ligand dissociation constants from competition binding assays: errors associated with ligand depletion. Mol Pharmacol, 1987. 31(6): p. 603-9.

29. Carter, C.M., J.R. Leighton-Davies, and S.J. Charlton, Miniaturized receptor binding assays: complications arising from ligand depletion. J Biomol Screen, 2007. 12(2): p. 255-66. 


\section{CHAPTER 3}

\section{A 96-well filtration method for radioligand binding analysis of sigma receptor ligands}




\subsection{Abstract}

Sigma receptors represent a potential drug target for numerous therapeutic indications including cancer, depression, psychostimulant abuse, and stroke. To date, no in vitro assays have been developed which are amenable to routine use for determining the functional activity of novel sigma ligands. As a result, radioligand binding assays are currently used as a primary screen to identify promising candidates for in vivo studies. Most published radioligand binding studies for sigma receptors utilize a low throughput method employing a "cell harvester." Higher throughput methods are required to facilitate more efficient screening of the large numbers of novel compounds our laboratory routinely analyzes for binding to sigma receptors. This study compared binding affinities determined with a new medium-throughput 96-well filtration method to results obtained using the conventional cell harvester-based method. The 96-well assay utilized rat liver membranes for the determination of both known sigma receptor subtypes $(\sigma 1$ and $\sigma 2$ ) because this tissue contains high densities of both subtypes and fulfils criteria required for reliable use with the 96 -well format. The new method was shown to give comparable $\mathrm{K}_{\mathrm{i}}$ values for reference ligands, and a novel series of $2(3 \mathrm{H})$-benzothiazolone compounds, analyzed in parallel with samples prepared in rat brain membranes and processed on the traditional cell harvester. For $\sigma 1$ receptors equivalent affinity values were observed for both methods/tissues. For $\sigma 2$ receptors, approximately 2 -fold higher affinities were observed for most compounds in liver membranes as compared to brain membranes but excellent correlation with brain-derived values was maintained. Analysis of the $2(3 \mathrm{H})$-benzothiazolone series identified several new compounds with nanomolar affinity and greater than 50-fold specificity for $\sigma 1$ versus $\sigma 2$ receptors. Further, because dramatic differences in subtype binding were observed in this synthetic series, this study also provided useful data for the continued development of pharmacophore models for both sigma receptor subtypes. 


\subsection{Introduction}

The sigma receptor was first described as an opioid receptor subtype based on the behavioral effects of $N$-allylnormetazocine (SKF-10,047) in dogs [1]. Subsequent in vitro radioligand binding studies revealed that the binding site for prototypic sigma ligands was a protein distinct from opioid receptors $[2,3]$. Currently, two subtypes of sigma receptors are recognized, $\sigma 1$ and $\sigma 2$; these subtypes can be distinguished by differences in ligand selectivity, tissue distribution and molecular properties. Because sigma receptors are recognized as potential therapeutic and radioprobe targets, research to ascribe in vitro and in vivo activities to the respective subtypes is a major focus of sigma receptor research [4-8]. Consequently, to facilitate these studies, efforts to synthesize and identify novel subtype selective agonist and antagonist compounds are ongoing.

There are currently no accepted in vitro assays for routinely testing sigma receptor ligand activities; therefore, radioligand binding serves a critical role in screening novel ligands. Radioligand competition binding assays using a conventional cell harvester represent a bottleneck in the development of new sigma ligands due to the low throughput nature of the format. 96-well filtration offers the potential to increase throughput and reduce costs for routine radioligand binding assays.

Previous reports of the use of 96 well filtration methodologies for the analysis of sigma receptor binding are limited to two research groups [9-14]. The Mach group from Washington University were the first to report the use of 96-well filter plates for the analysis of sigma receptor binding [11]. In these initial studies binding to $\sigma 2$ receptors in crude rat liver homogenate, and in human and mouse tumor xenografts was examined with $\left[{ }^{3} \mathrm{H}\right] \mathrm{DTG}$ and a novel $\sigma 2$ specific radioprobe, $\left[{ }^{3} \mathrm{H}\right]$ RHM-1 (N-[4-(3,4-dihydro-6,7-dimethoxyisoquinolin-2(1H)-yl)butyl]-2-methoxy-5-met hyl-benzamide). Later studies extended the technique to the determination of $\sigma 1$ affinities in guinea-pig brain membranes labeled with $\left[{ }^{3} \mathrm{H}\right](+)$-pentazocine $[9,13,14]$. A more recent study reported by the Wünsch group from the University of Münster examined binding at both sigma subtypes utilizing "filtermats," an alternative filter format designed for 96-well use [10]. The results of these studies suggested that 96-well filtration is a viable approach for separation of free 
from receptor bound radioligand for sigma receptor binding studies. However, to support future routine use of the 96-well filtration based process, additional confirmation that results obtained using the method produces results equivalent to the more established cell harvester-based methods is needed.

The majority of contemporary sigma receptor binding studies are performed with P2 membranes prepared from guinea-pig brain for assaying $\sigma 1$ receptor binding, and rat liver P2 membranes for assaying $\sigma 2$ receptors, because these tissues are enriched in the respective subtypes $[9,10,15$, 16]. Reported values for $B_{\max }$ of $\sigma 1$ in rodent brain $P 2$ vary, ranging from approximately 300 to $500 \mathrm{fmol} / \mathrm{mg}$ for rat brain $[17,18]$, and approximately $575 \mathrm{fmol} / \mathrm{mg}$ to $2.0 \mathrm{pmol} / \mathrm{mg}$, for guineapig brain [19-22]. The published $\mathrm{B}_{\max }$ value for $\sigma 2$ receptors in rat liver $\mathrm{P} 2$ is $\sim 9 \mathrm{pmol} / \mathrm{mg}$ [23].

Receptor expression levels of $2 \mathrm{pmol} / \mathrm{mg}$ or greater are required for detection with tritiated ligands and the typical sample sizes of 2-100 $\mu \mathrm{g}$ total protein per well used in 96-well filtration assays [24-26]. This requirement is due to the limited filtration capacity of 96-well filter plates and the relatively low specific activity of tritium. Because the reported expression level for $\sigma 1$ receptors in guinea-pig brain varies and the highest reported level of $2.0 \mathrm{pmol} / \mathrm{mg}$ [19] just meets the minimum criteria for processing by 96 -well filtration we sought a tissue with greater $\sigma 1$ receptor expression levels.

Rat liver P2 contains high densities of both subtypes of sigma receptors [23, 27, 28]; representative $B_{\max }$ values determined for $\sigma 1$ and $\sigma 2$ are $\sim 3 \mathrm{pmol} / \mathrm{mg}$ and $\sim 9 \mathrm{pmol} / \mathrm{mg}$ respectively [23]. It has also been reported that rat brain and rat liver homogenates yield similar affinity values for binding of $\sigma 1$ reference ligands [28-30], and as stated previously, rat liver is already the established preferred tissue for $\sigma 2$ binding studies [31]. Rat liver was thus chosen for development of this assay.

Despite the reported equivalency of rat liver and rat brain membranes for the determination of $\sigma 1$ binding [28-30] it was necessary to rigorously demonstrate that the two tissues would yield similar results in our hands using the 96-well filtration platform. Uncharacterized differences in lipid composition, protein partners, and cellular distributions of $\sigma 1$ in $\mathrm{P} 2$ isolates of the two 
tissues may introduce unanticipated artifacts that impact affinity measurements. Known differences in lipid compositions of whole organ homogenates of rat liver compared to rat brain include: 1) higher amounts of phosphatidylcholine in liver, 2) higher amounts of phosphatidylethanolamine in brain, and 3) the presence of cerebrosides and sulfatides in brain that are not found in liver [32]. The relative distribution of these lipids in P2 membranes isolated by our methods has not been reported; therefore, it is not known if the differences observed in whole tissue homogenates are reflected in this fraction.

Determinations of $\sigma 2$ binding may also be influenced by differences in lipid composition or protein partners in the two tissues. Because $\sigma 2$ receptors reside in lipid rafts, and behave very differently to detergent extraction relative to $\sigma 1$ receptors [33, 34], lipid composition differences in the two tissues may be an important consideration. Despite the continued use of brain tissues by some researchers for the determination of $\sigma 2$ receptor binding affinities [35-38], there have been no rigorous comparisons of binding at $\sigma 2$ in brain versus liver membranes. Furthermore, it has not been conclusively established that $\sigma 2$ receptors present in the brain are the same protein as those found in liver.

Extending on earlier work by Ucar et al. [39], Yous et al. [40] reported a structure-binding affinity study for a small series of benzothiazolone compounds with high affinity and specificity for sigma receptors. In this study they identified SN56 (3-(2-(azepan-1-yl)ethyl)-6propylbenzo[d]thiazol-2(3H)-one) as a new sigma receptor specific ligand with nanomolar affinity and unprecedented selectivity for the $\sigma 1$ versus the $\sigma 2$ subtype and versus a battery of non-sigma receptors and neurotransmitter transporters [40]. More recent in vivo and in vitro data suggested SN56 as a promising lead compound for further investigations of additional 2(3H)benzothiazolone analogues [41]. We have shown that $\left[{ }^{3} \mathrm{H}\right] \mathrm{SN} 56$ yields a similar pharmacological profile compared to the universally accepted o1 radioprobe, $\left[{ }^{3} \mathrm{H}\right](+)$-pentazocine [41]. Additionally, behavioral studies performed in our laboratory demonstrated that SN56 protected mice against cocaine-induced convulsions (unpublished data), similar to other established $\sigma 1$ antagonists [42-45]. 
In the present report, in addition to a series of reference compounds, a series of novel $2(3 \mathrm{H})$ benzothiazolone compounds were analyzed for binding to sigma receptors to validate the method for routine use. The reference compounds used in this study represent known sigma ligands with well-established pharmacological characteristics. The 2(3H)-benzothiazolone compounds examined included variations in: 1) the size of the attached heterocycle, 2) the heterocycle linker chain length, and 3) the composition of the alkyl or acyl chain at position 6 of the 2(3H)benzothiazolone system. Following successful demonstration that the proposed 96-well method gave satisfactory results with the reference compounds, the binding affinities of the $2(3 \mathrm{H})$ benzothiazolone compounds for sigma receptors were determined.

Because radioligand binding assays serve a significant role in identifying new sigma ligands and current methods do not meet our current throughput needs, we sought to develop a higher throughput method. We chose to examine a 96-well filtration format and evaluated the procedure with reference ligands and analogues of the 2(3H)-benzothiazolone compound, SN56. The method employed rat liver membranes for the determination of binding at both $\sigma 1$ and $\sigma 2$ receptors. Binding affinities determined with this new method were compared to measurements generated using conventional filtration to qualify the validity of this new approach for routine screening of novel sigma ligands.

\subsection{Materials and Methods}

\subsubsection{Chemicals and Reagents}

$\left[{ }^{3} \mathrm{H}\right](+)$-Pentazocine (specific activity $=29 \mathrm{Ci} / \mathrm{mmol}$ ) and $\left[{ }^{3} \mathrm{H}\right] \mathrm{DTG}$ (specific activity $=53.3$ $\mathrm{Ci} / \mathrm{mmol}$ ) were purchased from Perkin Elmer (Boston, MS). (+)-Pentazocine, (-)-pentazocine, (+)- $N$-allylnormetazocine hydrochloride, 1,3-di-o-tolylguanidine (DTG), haloperidol, progesterone, dextromethorphan hydrobromide, rimcazole dihydrochloride monohydrate, sucrose, $\mathrm{NaCl}$, dimethylsulfoxide (DMSO) and tris(hydroxymethyl)aminomethane (Tris), were purchased from Sigma-Aldrich (St. Louis, MO). NE100 (4-methoxy-3-(2-phenylethoxy)- $N, N$ dipropylbenzeneethanamine hydrochloride), BD1063 (1-[2-(3,4-dichlorophenyl)ethyl]-4methylpiperazine dihydrochloride), and fluvoxamine maleate were obtained from Tocris Bioscience (Ellisville, MO). AC927 (N-phenethylpiperidine oxalate) was provided by Dr. 
Andrew Coop from the University of Maryland (Baltimore, MD). SN56 (3-(2-(azepan-1yl)ethyl)-6-propylbenzo[d]thiazol-2(3H)-one) and the RB compound series (see Table 2) were provided by the laboratory of Dr. Christopher McCurdy from the University of Mississippi (University, MS). Coomassie Protein Assay reagent, 1N hydrochloric acid, glacial acetic acid, Ecoscint, Microscint 20, Brandel GF/B filter papers, 2.25 x 12.25 inches, and Unifilter-96 GF/B filter plates were purchased from Fisher Scientific (Pittsburgh, PA).

\subsubsection{Membrane preparation}

Rat brain P2 and rat liver P2 fractions were prepared as described previously and outlined below from frozen tissues obtained from Pel-Freeze (Rogers, AR) [46]. Tissues were homogenized batch-wise with a Potter-Elvehjem homogenizer (5-10 strokes with motor driven Teflon pestle) in ice-cold $10 \mathrm{mM}$ Tris-sucrose buffer (0.32 M sucrose in $10 \mathrm{mM}$ Tris, $\mathrm{pH} 7.4)$ using $10 \mathrm{ml}$ buffer per $\mathrm{g}$ of tissue with $\sim 3 \mathrm{~g}$ of tissue per batch. Homogenates from multiple batches were combined and centrifuged for $10 \mathrm{~min}$ at $1,000 \mathrm{x} \mathrm{g}$, at $4{ }^{\circ} \mathrm{C}$. Supernatants were decanted, combined and centrifuged for $15 \mathrm{~min}$ at $31,000 \mathrm{x} \mathrm{g}, 4{ }^{\circ} \mathrm{C}$. To reduce levels of bound endogenous ligand(s) the resulting $\mathrm{P}_{2}$ membrane was washed as follows: 1) pellets were re-suspended in 10 $\mathrm{mM}$ Tris, $\mathrm{pH} 7.4$ using $3 \mathrm{ml}$ buffer per $\mathrm{g}$ of wet tissue, 2) the resulting suspension was incubated for $30 \mathrm{~min}$ at $25{ }^{\circ} \mathrm{C}, 3$ ) following incubation, the suspension was centrifuged for $15 \mathrm{~min}$ at $31,000 \mathrm{x} \mathrm{g}$, at $4{ }^{\circ} \mathrm{C}$. The resulting pellets were re-suspended in $10 \mathrm{mM}$ Tris, $\mathrm{pH} 7.4$ buffer at a final concentration of $1 \mathrm{~g}$ starting tissue weight/1.5 ml. Tissue preparations were aliquoted in 1 $\mathrm{ml}$ portions and stored at $-80{ }^{\circ} \mathrm{C}$. The Bradford assay was used to quantitate protein concentration (Bradford, 1976).

\subsubsection{6-well filtration with rat brain membrane}

The 96-well filtration method was tested with rat brain P2 membranes to confirm that this material was incompatible with processing using the 96-well filtration plates. Samples were prepared and processed as described below for competition binding assays of rat liver processed by $96-w e l l$ filtration except samples contained 25,50 or $100 \mu \mathrm{g} /$ well rat brain P2 membrane instead of rat liver P2 membrane. Each membrane concentration was assayed in triplicate for total and non-specific binding. Full sample plates containing 100 and $200 \mu \mathrm{g} /$ well were also prepared and processed to confirm that the results of the samples described above were not 
compromised by loss of vacuum pressure due to the use of varied membrane concentrations in individual test wells. These samples were prepared in a total volume of $0.5 \mathrm{~mL} / \mathrm{well}$ to more faithfully duplicate typical samples prepared for filtration using the Brandel harvester.

\subsubsection{Binding linearity with rat liver membranes processed by 96-well filtration}

To determine the appropriate amount of rat liver membrane to use in competition binding assays processed by 96-well filtration, binding linearity studies were performed for both sigma receptor subtypes. Samples were prepared and processed as described below for competition binding assays. Samples contained 0, 10, 20, 30, 40, 50, or $60 \mu \mathrm{g} /$ well rat liver membrane. Each membrane concentration was assayed in triplicate for total and non-specific binding.

\subsubsection{Competition binding assays}

To test the suitability of the 96-well filtration method for routine use in determining sigma ligand binding affinities, a series of sigma reference ligands were assayed using the 96-well method and re-assayed using the conventional cell harvester-based method. Following successful demonstration of the correlation between the two processes, a series of $2(3 \mathrm{H})$-benzothiazolone compounds were assayed with the 96-well filtration method.

Radioligand binding assays utilized optimized buffer and incubation conditions that are consistent with those reported in the literature for the analysis of sigma receptor binding [20, 23, 47]. Stock solutions of test ligands were prepared in DMSO or deionized water at 5 or $25 \mathrm{mM}$. Dilutions of reference ligands for competition studies were made with assay buffer (50 mM Tris, $\mathrm{pH}$ 8). Dilutions of 2(3H)-benzothiazolone analogues were prepared in $1 \mathrm{mM} \mathrm{HCl}$. The use of 1 $\mathrm{mM} \mathrm{HCl}$ for dilution of $2(3 \mathrm{H})$-benzothiazolone analogues was required to reduce binding of these compounds to glass tubes or polypropylene microplates and had no effect on the final $\mathrm{pH}$ of the samples or on total binding relative to samples prepared in assay buffer alone (data not shown). For samples requiring DMSO for solubilization, a final concentration of up to 1-2\% DMSO in assay samples had no effect on total binding.

Assays with rat brain were processed using a Brandel R48 harvester (Gaithersburg, MD), and assays with rat liver were processed using a Connectorate 96-well harvester (Dietikon, 
Switzerland). For compounds assayed with brain homogenate, $400 \mu \mathrm{g}$ of rat brain P2 membrane was added to a glass test tube containing test ligand and radioligand in assay buffer in a final volume of $0.5 \mathrm{ml}$. For compounds analyzed with rat liver homogenate, $40 \mu \mathrm{g}$ of rat liver P2 membrane was added to a polypropylene plate (catalogue number 07-200-697, Fisher Scientific) containing test ligand and radioligand in assay buffer in a total volume of $0.25 \mathrm{ml}$.

Assays for $\sigma_{1}$ receptors used a final concentration of $5 \mathrm{nM}\left[{ }^{3} \mathrm{H}\right](+)$-pentazocine. Labeling of $\sigma_{2}$ was effected with either $3 \mathrm{nM}\left[{ }^{3} \mathrm{H}\right] \mathrm{DTG}$ for brain membranes, or $5 \mathrm{nM}\left[{ }^{3} \mathrm{H}\right] \mathrm{DTG}$ for liver membranes; these samples also contained $300 \mathrm{nM}$ (+)-pentazocine (to block $\sigma_{1}$ receptors). The concentrations of radioligand stock solutions were calculated based on CPM measurements and specific activities reported by the manufacturer. Nonspecific binding (NSB) was determined by the addition of haloperidol to a final concentration of $10 \mu \mathrm{M}$. Samples were incubated for 120 min at $25^{\circ} \mathrm{C}$ for all assays. Samples prepared in test tubes and processed with the Brandel harvester were vortexed prior to incubation; samples prepared in microplates for 96-well filtration were agitated during incubation on a 96-well plate shaker. Following incubation, samples were filtered and washed. Samples processed on the Brandel cell harvester were washed 3 times with $3 \mathrm{ml}$ of $10 \mathrm{mM}$ Tris, $\mathrm{pH}$ 8. Samples processed by 96 -well filtration were washed 5 times with $0.2 \mathrm{ml}$ of $10 \mathrm{mM}$ Tris, $\mathrm{pH}$ 8. Prior to use GF/B filter papers and Unifilter GF/B filter plates were soaked in $0.5 \%$ polyethyleneimine (PEI) for $30 \mathrm{~min}$ to reduce non-specific binding.

For the determination of binding affinities, each test compound was assayed at 11 concentrations varying from $0.001-10 \mu \mathrm{M}$. Samples were prepared and processed in duplicate for each binding curve and triplicate determinations of binding curves were made for each compound. Samples for the determination of total and non-specific binding for each experiment were run concurrently and filtered simultaneously. Following washing, filters processed on the Brandel harvester were transferred to scintillation vials and $3 \mathrm{ml}$ scintillation cocktail was added to each sample. Filters were allowed to soak in cocktail for a minimum of $10 \mathrm{~h}$ prior to counting on a Beckman LS6500 scintillation counter (Brea, CA). Samples processed by 96-well filtration were counted on a Perkin Elmer Microbeta2 2450 microplate counter (Waltham, MA), in the Unifilter plates, following a $2 \mathrm{~h}$ incubation at room temperature with $40 \mu \mathrm{l}$ Microscint-20 cocktail per well. 


\subsubsection{Data analysis}

The competition binding data were analyzed with GraphPad Prism software (San Diego, CA) using a one-site nonlinear regression model to determine the concentration of ligand that inhibits $50 \%$ of the specific binding of the radioligand $\left(\mathrm{IC}_{50}\right.$ value). $\mathrm{K}_{\mathrm{i}}$ values were calculated from the $\mathrm{IC}_{50}$ using the Cheng-Prusoff equation [48]. To compare binding data from conventional binding experiments to the 96-well filtration method, correlation plots were generated with GraphPad Prism, using a two-tailed fit with the assumption that data were sampled from Gaussian populations (Pearson $r$ ). For comparison of individual $\mathrm{K}_{\mathrm{i}}$ values obtained using rat liver versus rat brain a two-tailed t-test was performed using InStat software (San Diego, CA). Hill plots of competition binding data were determined with GraphPad Prism software using the "sigmoid dose-response (variable slope)" equation. Partition coefficients adjusted for $\mathrm{pH}(\operatorname{logD})$ were calculated using ACD Labs, I-Lab 2.0 (v5.0.0.184, Toronto, Ontario, Canada).

\subsection{Results}

\subsubsection{6-well filtration with rat brain membrane}

Samples of rat brain membrane were prepared and processed using the 96-well filtration format to confirm that this material did not contain high enough expression levels of $\sigma 1$ receptors to be compatible with analysis by this method. Percent non-specific binding (\% NSB) for 0, 25, 50 and $100 \mu \mathrm{g}$ membrane/well was 93\%, 92\%, 76\% and 59\% respectively. Wells containing $100 \mu \mathrm{g}$ membrane/well appeared to clog as evidenced by incomplete emptying of wash solution from the sample plate. The full plates prepared with 100 or $200 \mu \mathrm{g}$ membrane/well also appeared to clog with membrane; despite the appearance that the samples transferred to the filters, washing was not possible.

\subsubsection{Binding linearity with rat liver membranes}

To determine the appropriate amount of rat liver P2 membrane to use in competition assays with 96-well filtration, a binding linearity study was performed for both receptor subtypes using conditions optimized from preliminary experiments. Figures 1 and 2 show that binding of both $\left[{ }^{3} \mathrm{H}\right](+)$-pentazocine and $\left[{ }^{3} \mathrm{H}\right] \mathrm{DTG}$ (in the presence of $300 \mathrm{nM}(+)$-pentazocine) increased 
linearly from 0 to $50 \mu \mathrm{g}$ rat liver P2 membrane (total protein) added per well. Non-specific binding also increased linearly and remained a constant percent of total binding throughout the linear range of total binding. For $\sigma 1$ receptors non-specific binding was 15-20\% of total binding; for $\sigma 2$ receptors, non-specific binding was $10-15 \%$ of total binding. For $\sigma 2$ binding assays a titration experiment confirmed that $300 \mathrm{nM}(+)$-pentazocine was sufficient to adequately block $\sigma 1$ receptors without significantly impacting $\sigma 2$ binding. Based on these results competition binding studies for all compounds analyzed by 96 -well filtration utilized $40 \mu \mathrm{g}$ liver membrane per well. This amount of membrane ensured that $<10 \%$ of added radioligand bound to sigma receptors (in this case radioligand binding was $<3-4 \%$ of added label), a requirement for application of competition binding algorithms based on the laws of mass action [49]. Nonspecific binding for samples prepared with rat brain and processed with the Brandel harvester averaged $40-50 \%$ for $\sigma 1$ receptors and $30-40 \%$ for $\sigma 2$ receptors.

\subsubsection{Binding affinities of reference ligands}

Sigma receptor binding affinities for individual reference compounds as reported in the literature and as determined in this study are shown in Table 2 and Table 3, for $\sigma 1$ and $\sigma 2$ receptors respectively. Overall, values obtained for sigma binding in rat brain P2 from this study were similar to values reported in the literature, where measurements were made with similar experimental conditions in either rat or guinea-pig brain fractions (see legend to Table 2). Likewise, similar $\sigma 1$ binding affinities were observed for samples analyzed in this study with liver P2 versus brain P2 for all reference compounds with the exception of those compounds with low affinity: progesterone, dextromethorphan and rimcazole; these compounds showed statistically significant higher affinities in liver as compared to brain (progesterone, $\mathrm{P}<0.001$; dextromethorphan, $\mathrm{P}<0.005$; rimcazole, $\mathrm{P}<0.001)$. At $\sigma 2$ receptors, all compounds tested showed higher affinity in liver versus brain, with most compounds displaying an approximately 2-fold higher affinity in liver compared to brain; the difference was statistically significant, for six of the ten compounds tested (DTG, P < 0.005; haloperidol, $\mathrm{P}<0.001$; NE100, $\mathrm{P}<0.001$; $\mathrm{BD} 1063, \mathrm{P}<0.001$; AC927, $\mathrm{P}<0.005$; and fluvoxamine, $\mathrm{P}<0.005)$. Figure 3A shows correlation plots for $\sigma 1$ binding in rat liver P2 versus rat brain P2 as determined in this study (Pearson $r=0.97$ ), and Figure 3B shows binding in rat brain P2 versus literature values for rat or guinea-pig brain membranes (Pearson $r=0.95$ ). Figure $4 \mathrm{~A}$ shows a correlation plot for $\sigma 2$ 
binding in rat liver P2 versus rat brain P2 as determined in this study (Pearson $r=0.98$ ), and Figure 3B shows binding in rat brain P2 versus literature values for rat or guinea-pig membranes (Pearson $r=0.95$ ). Pearson $r$ values for these plots indicate that binding is proportional over a four $\log$ range of $\mathrm{K}_{\mathrm{i}}$ values for $\sigma 1$ receptors and an approximately two and a half log range for $\sigma 2$ receptors in rat liver $\mathrm{P} 2$ versus rat brain $\mathrm{P} 2$.

\subsubsection{Binding affinities of 2(3H)-benzothiazolone analogues}

Sigma receptor binding affinities determined in this study for individual test compounds are shown in Table 4. The parent compound structure is shown in Figure 5 where $\mathrm{R}$ represents the appended alkyl or ketonyl chain, m represents ring size, and $\mathrm{n}$ represents linker chain length. Some general trends observed include: 1) a reversal in selectivity from $\sigma 1$ to $\sigma 2$, for azepine ring compounds $(m=2)$ with increasing linker arm length (from $n=2$ to $n=5)$, reflecting marginal changes in affinity at $\sigma 1$ and significant increases in affinities for the $\sigma 2$ subtype, 2) reduced affinity for both sigma subtypes when the azepine ring of SN56 was replaced with a pyrrolidine ring $(\mathrm{m}=0)$, as demonstrated by RB65 and RB75, and 3) a dramatic decrease in $\sigma 2$ affinity with a marginal change in $\sigma 1$ affinity for linker length $\mathrm{n}=1$, with an azepine ring, and a change of the chain at position 6 from $\left(\mathrm{CH}_{2}\right)_{2} \mathrm{CH}_{3}$ to $\mathrm{COCH}_{2} \mathrm{CH}_{3}$, as demonstrated by SN56 and RB74. The $\mathrm{K}_{\mathrm{i}}$ $\sigma 2 / K_{i} \sigma 1$ value of 483 for RB74 versus 168 for SN56 represents an approximately 3-fold improvement in $\sigma 1$ selectivity, primarily due to an almost 8 -fold decrease in affinity at $\sigma 2$ for RB74 versus SN56.

\subsubsection{Pseudo-Hill coefficients for competition binding curves}

Pseudo-Hill coefficients (pseudo- $n_{\mathrm{H}}$ ) were calculated to determine if the competition binding data was consistent with a reversible bimolecular interaction following the laws of mass action $[50,51]$. No samples yielded a pseudo-Hill coefficient significantly different from unity; no deviations greater than 0.15 were observed. Where a sample deviated greater than 0.1 from unity visual inspection of the curve overlaid with a curve generated with the slope constrained to unity suggested the calculated value was anomalous. Because the pseudo-Hill coefficient describes the equilibrium between both the labeled and unlabeled compounds with the receptor, small deviations can be expected $[50,51]$. 


\subsubsection{Binding affinity versus lipophilicity for 2(3H)-benzothiazolone analogues}

To determine if there was a correlation between the lipophilicity of the appended $\mathrm{R}$ group at position 6 on the $2(3 \mathrm{H})$-benzothiazolone base structure, and binding affinity among homologues with similar linker chain lengths, a plot of $\log \mathrm{K}_{\mathrm{i}}$ versus $\log \mathrm{D}$ was generated. $\log \mathrm{D}$ was calculated using ACD Labs software and are tabulated for $\mathrm{pH}=8$ because this was the $\mathrm{pH}$ used for the binding determinations. The results for all compounds are shown in Table 7. The plot of $\log \mathrm{K}_{\mathrm{i}}$ versus $\log \mathrm{D}$ for the homologous compounds is shown in Figure 6. For $\mathrm{n}=2 \mathrm{a}$ change in the $\mathrm{R}$ group from $\mathrm{H}$ to $\left(\mathrm{CH}_{2}\right)_{2} \mathrm{CH}_{3}$ resulted in a change in $\log \mathrm{D}$ from 1.52 to 2.82 with a concomitant 10 -fold increase in affinity at $\sigma 2$. Similarly for $n=3$ the change from $\mathrm{H}$ to $\left(\mathrm{CH}_{2}\right)_{2} \mathrm{CH}_{3}$ resulted in a change in $\log \mathrm{D}$ from 1.47 to 2.60 with a concomitant 23.5 -fold increase in affinity at $\sigma 2$. For $\mathrm{n}=2$ a change from $\left(\mathrm{CH}_{2}\right)_{2} \mathrm{CH}_{3}$ to $\left(\mathrm{CH}_{2}\right)_{3} \mathrm{CH}_{3}$ resulted in a change in $\operatorname{logD}$ from 2.82 to 3.14 that resulted in almost no change in affinity from $\mathrm{K}_{\mathrm{i}}=17.2$ to $15.3 \mathrm{nM}$. A similar effect was observed with the $n=3$ compounds. For $n=4$ and $n=5$ the transition from $\mathrm{H}$ to $\left(\mathrm{CH}_{2}\right)_{2} \mathrm{CH}_{3}$ to $\left(\mathrm{CH}_{2}\right)_{3} \mathrm{CH}_{3}$ resulted in significant increases in $\log \mathrm{P}$ with insignificant changes in $\mathrm{K}_{\mathrm{i}}$. When the $\mathrm{R}$ group was changed from $\mathrm{COCH}_{2} \mathrm{CH}_{3}$ to $\mathrm{CO}\left(\mathrm{CH}_{2}\right)_{2} \mathrm{CH}_{3}$ insignificant changes were observed in $\mathrm{K}_{\mathrm{i}}$ with an increase of $\log \mathrm{D}$ from 2.23 to 2.72 for $\mathrm{n}=2,2.16$ to 2.25 for $\mathrm{n}=3,1.7$ to 2.47 for $\mathrm{n}=4$ and 2.37 to 2.67 for $\mathrm{n}=5$. 


\subsection{Discussion}

In this study a 96-well method for radioligand competition binding was evaluated for routine use in the determination of sigma ligand binding affinities. The results for binding of reference ligands to rat liver P2 membranes analyzed with the 96-well method demonstrated excellent correlation with values derived in rat brain P2 membranes assayed using the conventional Brandel-based method, for both $\sigma 1$ and $\sigma 2$ receptor subtypes. These results suggest that 96 -well filtration is a suitable alternative to Brandel filtration for the analysis of sigma receptor radioligand binding. Application of the assay to the analysis of a novel series of $2(3 \mathrm{H})$ benzothiazolone compounds identified several new $\sigma 1$ selective analogues and provided structure-binding affinity data that distinguish structural features which confer subtype selectivity for this compound class. Our data also showed that $\sigma 2$ receptors derived from rat liver P2 appear to exhibit higher affinity for sigma ligands than those isolated from rat brain P2, a result that has not been previously reported. The source of this difference is unknown but should be considered when comparing relative binding to $\sigma 1$ versus $\sigma 2$ receptors where binding determinations are made in homogenates from different tissues.

The 96-well method detailed here is an adaptation of the approach commonly described in the literature for analysis of sigma receptor competition binding, where typical studies utilized a Brandel "cell harvester" for separation of free from bound radioligand. Conversion of the method to a 96-well format was proposed to facilitate greater throughput in our routine sigma receptor binding screens of new putative sigma ligands. Adaptation of the conventional method for radioligand binding assays of $\sigma 1$ receptors to the 96-well method required the use of rat liver membranes instead of the more commonly used rat or guinea-pig brain derived P2 membranes. This requirement was necessitated by filtration capacity limitations imposed by the 96-well filter configuration as well as additional considerations related to improving reproducibility for medium throughput screening as discussed below.

Our studies with rat brain membranes processed by 96-well filtration indicated that $100 \mu \mathrm{g}$ of rat brain P2/sample well resulted in clogging of the 96-well filterplates, and lower amounts of membrane did not generate adequate signal for reliable measurements. In contrast, the 96-well 
assay using rat liver membranes only required $40 \mu \mathrm{g}$ of membrane to achieve adequate signal, and $>60-80 \mu \mathrm{g}$ resulted in radioligand depletion. We did not test guinea-pig brain P2 because reported values of $\sigma 1$ expression in this tissue were variable and the highest reported value of 2 $\mathrm{pmol} / \mathrm{mg}$ [21] just met the minimum criteria for use with tritiated radioligands and the sample size limitations imposed by the 96-well filterplates. Additionally, as outlined below it was our desire to utilize one tissue for assaying both receptor subtypes and neither guinea-pig nor rat brain contain adequate levels of $\sigma 2$ receptors to support this goal.

We did not observe significant differences in binding affinities for $\sigma 1$ receptors between the two assay methods for the majority of reference ligands tested. Because the $\sigma 1$ receptor protein appears well conserved among species and there is no evidence for differences in the protein in brain versus liver, the choice of liver as a source of $\sigma 1$ receptors was not expected to greatly impact affinity measurements [28, 52-56]. Moreover, binding studies with different crude membrane preparations, sub-cellular fractions and solubilized extracts derived from brain and liver from rat and guinea-pig, indicate that affinities of ligands for $\sigma 1$ remain essentially constant despite the varied sources of receptors [23, 27-30, 57-59]. However, the cell biology of sigma receptors is still being elucidated and previously undetected differences may exist so a systematic comparison was needed. The observation that the low affinity compounds, progesterone, dextromethorphan and rimcazole, showed statistically significant higher binding affinities in liver membranes versus brain membranes is in agreement with previous observations reported by Klouz et al. [29, 30]; however, the source of this difference is unknown.

Our observation that most of the reference ligands tested bound with higher affinity to $\sigma 2$ receptors isolated from liver compared to brain was unexpected. The differences were statistically significant for six of the ten compounds tested. While conclusive evidence for the source of the observed differences is lacking, we propose three possible factors that may contribute to ligands showing higher affinity in liver relative to brain: 1) differences in lipid and/or protein partners associated with $\sigma 2$ in the two organ isolates, 2) the existence of unidentified heterogeneous populations of $\sigma 2$-like receptors, with similar binding properties, that cannot be discriminated with existing techniques, and 3) an assay artifact due to an approximately 3.5-fold higher receptor concentration employed in liver membrane assays versus 
brain membrane assays. It should also be noted that because the $\sigma 2$ receptor has not been purified to homogeneity, it has not been established that $\sigma 2$ receptors present in the brain are the same protein as $\sigma 2$ receptors found in the liver.

A few points are worth noting regarding the apparent difference in binding affinity for $\sigma 2$ receptors from liver P2 versus brain P2 membranes. Published studies show that $\sigma 2$ receptors reside in lipid rafts [33, 34], and differences in binding of $\left[{ }^{3} \mathrm{H}\right] \mathrm{DTG}$ (with $\sigma 1$ blocking) have been observed in partially solubilized rafts isolated from the rat liver P2 fraction using different detergents $\left(\mathrm{K}_{\mathrm{d}}=\sim 23 \mathrm{nM}\right.$ in $20 \mathrm{mM}$ CHAPS versus $\mathrm{K}_{\mathrm{d}}=\sim 170 \mathrm{nM}$ in $1 \%$ Triton X-100) but fully solubilized preparations in these same detergents showed equivalent binding affinities [33, 34]. This suggests that the binding affinity of $\sigma 2$ can be influenced by manipulating the composition of lipids and/or proteins that associate with it. Thus, the different complement of lipids found in the brain versus the liver may result in a $\sigma 2$ receptor with slightly lower binding affinity. This observation contrasts with the behavior of the $\sigma 1$ receptor which appears to maintain consistent binding affinity for ligands in different sub-cellular fractions, soluble extracts, in purified form, and in lipid reconstituted purified forms [27, 28, 57, 60]. With regard to the effect of a $\sim 3.5$-fold higher concentration of $\sigma 2$ receptors in samples prepared with liver membranes $(0.04 \mathrm{mg}$ x 9000 $\mathrm{fmol} / \mathrm{mg}$ in $0.25 \mathrm{ml}=1440 \mathrm{fmol} / \mathrm{ml})$ versus those made with brain membranes $(0.4 \mathrm{mg} \times 500$ $\mathrm{fmol} / \mathrm{mg}$ in $0.5 \mathrm{ml}=400 \mathrm{fmol} / \mathrm{ml}$ ), a higher receptor concentration alone would be expected to underestimate ligand affinity [61], where in this case an increased affinity was observed. The observed differences in binding affinities could still be the result of factors unassociated with receptor specific binding but the data from liver samples processed with both Brandel and 96well filtration (which gave nearly identical results) suggests this is not due to the filtration format per se.

As mentioned previously several factors contributed to our choice to use rat liver for all sigma receptor binding assays performed using the 96-well method. In addition to the historically demonstrated equivalence of brain and liver for $\sigma 1$ binding [28-30], and the almost universal use of rat liver for $\sigma 2$ determinations, the use of liver membranes has additional advantages, including: 1) the small amount of membrane required to generate adequate signal reduces the likelihood for clogging of filters, 2) the use of one tissue for determination of both sigma 
receptor subtypes allows a comparison of $\sigma 1$ versus $\sigma 2$ binding in a similar molecular environment where use of different tissues for determinations introduces some ambiguity in this measurement, and 3) one batch of liver membrane is adequate for assaying thousands of data points instead of hundreds per batch ( $50-100 \mathrm{~g}$ tissue/batch) for typical membrane preparation scales of rat or guinea-pig brains, facilitating added inter-assay consistency.

Many well characterized membrane bound receptors have been cloned and overexpressed in cultured cells for use in binding and functional assays. While the use of cultured cells as a source of membranes for sigma receptor binding has been reported their use is not widespread [62, 63]. Lee et al. [63] cloned human $\sigma 1$ into MCF7 cells and produced a cell line with $\mathrm{B}_{\max } \sigma 1=109 \pm$ $24 \mathrm{pmol} / \mathrm{mg}$. Membranes from this cell line were used to analyze a series of 32 compounds, including several of the reference compounds tested in this study. The $\mathrm{K}_{\mathrm{i}}$ values determined for (+)-pentazocine, haloperidol, BD1063, and (+)-SKF10,047, and fluvoxamine in their study [63] were similar to the values obtained in this study, suggesting that their system is valid for assessing $\sigma 1$ binding. A similar strategy for $\sigma 2$ is not possible at this time because this protein has not been cloned. However, Schepmann et al. [62] recently reported the use of human RT-4 cells in binding studies; RT-4 cells contain a moderate expression level of $\sigma 2$ receptors, $\left(\mathrm{B}_{\max } \sigma 2\right.$ $=\sim 2.1 \mathrm{pmol} / \mathrm{mg}, \mathrm{B}_{\max } \sigma 1=\sim 280 \mathrm{fmol} / \mathrm{mg}$ ). This cell line showed good agreement with binding in rat liver P2 membranes for the four reference compounds tested [62] and the cell line is commercially available. While these approaches may be valid, until they are tested more rigorously or adopted more widely it is difficult to justify making a switch from the more established tissue sources of sigma receptors.

The results obtained for the $2(3 \mathrm{H})$-benzothiazolone series examined in this study suggest the 96well filtration method is suitable for application to novel classes of sigma ligands for use in structure-binding affinity studies. A more thorough discussion of the implications of the results obtained for this series will be detailed by our collaborators at the University of Mississippi in a future publication. However, some preliminary conclusions may be drawn including: 1) increased chain length for the heterocycle linker arm results in loss of selectivity for the $\sigma 1$ subtype, reflecting marginal changes in $K_{i}$ at $\sigma 1$ and significant changes in $K_{i}$ for $\left.\sigma 2,2\right)$ RB74 was identified as a new $\sigma 1$-selective compound with a 3-fold higher selectivity for $\sigma 1$ versus $\sigma 2$ 
compared to the lead compound, SN56; RB74 had a $\mathrm{K}_{\mathrm{i}} \sigma 2 / \mathrm{K}_{\mathrm{i}} \sigma 1$ ratio of $\sim 500$ in rat liver P2, and 3) several analogues were identified which retained low nanomolar affinity for $\sigma 1$ and exhibited a more than 50-fold preference for $\sigma 1$ versus $\sigma 2$. Further, because dramatic differences in subtype binding were observed in this synthetic series, this study provides useful data for the continued development of pharmacophore models for both sigma receptor subtypes. It should be noted that the results of this study are consistent with previous reports of compounds with similar structures where a longer linker arm results in increased affinity at $\sigma 2[39,40]$.

Lipophilicity as measured by octanol/water partition coefficients $(\log \mathrm{D})$ has been shown to affect ligand binding [64-66]. Berardi et al. [66] reported correlations between $\log \mathrm{D}$ and $\sigma 2$ binding affinities for a series of piperazine and piperidine sigma ligands, where an increase in $\log \mathrm{D}$ for the piperazine compounds resulted in increased affinity, while increased $\log \mathrm{D}$ for the piperidine compounds resulted in a decrease in affinity. To examine the effect of lipophilicity on the binding of the $2(3 \mathrm{H})$-benzothiazolone compounds, $\log \mathrm{D}$ was calculated and compared to binding affinities determined in this study. No correlation between $\log \mathrm{D}$ and $\mathrm{K}_{\mathrm{i}} \sigma 2$ was noted for the data set considered as a whole. When homologous compounds with similar linker chain lengths were examined, a significant change in $\log \mathrm{D}$ resulted in a concomitant significant change in the Ki for $\sigma 2$ only for linker length $n=2$ and $n=3$ when the $\mathrm{R}$ group was changed from $-\mathrm{H}$ to $-(\mathrm{CH} 3)_{2} \mathrm{CH}_{3}$. Therefore, it does not appear that lipophilicity plays a major role in determining the binding affinity for the $2(3 \mathrm{H})$-benzothiazolone compounds examined in this study.

In light of the results obtained in this study caution should be exercised with respect to comparisons of $\sigma 2$ binding data generated from different organ tissues. Researchers often report $\mathrm{K}_{\mathrm{i}} \sigma 2 / \mathrm{K}_{\mathrm{i}} \sigma 1$ selectivity ratios, which due to potential tissue specific differences in binding at $\sigma 2$ may be misleading when comparing compounds reported by different groups. In contrast, binding at $\sigma 1$ appears to remain relatively consistent between rat or guinea-pig brain P2 and rat liver P2.

The 96-well filtration method presented here has several advantages compared to the conventional Brandel filtration based method. In addition to greatly reduced radioactive liquid, solid, vial and scintillation waste the 96-well method also eliminates several labor intensive steps 
and uses less radioligand compared to the Brandel method. Furthermore, because the 96-well method uses 1/10 the amount of membrane per sample, a single membrane preparation can be used to process much larger numbers of samples, which reduces inter-run variability and time spent preparing membranes. Over the course of this study we also observed approximately $1 / 2$ the number of "failed" runs versus the conventional filter method where a high non-specific binding signal compromised precise measurements with Brandel filtration. An additional advantage is that 96-well plates can be read $2 \mathrm{~h}$ after the addition of scintillation cocktail versus $10 \mathrm{~h}$ for filters from the Brandel; this means 96-well filterplate samples can be run the same day as they are processed whereas Brandel samples typically are run the day after processing.

In conclusion, we have demonstrated the suitability of a 96-well method for the analysis of sigma receptor binding. This method was validated by assaying reference compounds with the traditional Brandel cell harvester with rat brain P2 membranes and compared to results obtained with the 96-well filtration method using rat liver P2 membranes. Excellent correlations were observed between the two methods for the determination of binding to both $\sigma 1$ and $\sigma 2$ subtypes despite the use of different assay formats and tissue source for sigma receptors. The excellent correlation for binding of reference compounds at $\sigma 1$ in rat liver $\mathrm{P} 2$ versus rat brain $\mathrm{P} 2$ suggests affinities determined with the new method can be compared to historically reported results determined in rat or guinea-pig brain membranes. Additionally, because the method employs the same tissue source as is commonly used for $\sigma 2$ affinity determinations, the results for $\sigma 2$ binding obtained with this method can be compared directly to most reported results for this subtype. The validity of the method was further demonstrated by a successful structure-binding affinity analysis of a novel series of 2(3H)-benzothiazolone sigma receptor ligands. 
Table 1. Binding of $\left[{ }^{3} \mathrm{H}\right](+)$-pentazocine in rat brain $\mathrm{P} 2$ membranes processed by 96 -well filtration.

\begin{tabular}{|c|c|c|c|}
\hline $\begin{array}{c}\text { Rat brain } \\
\text { membrane } \\
(\mu \mathrm{g})\end{array}$ & $\begin{array}{c}\text { Non-specific } \\
\text { binding (CPM) }\end{array}$ & $\begin{array}{c}\text { Total binding, } \\
(\mathrm{CPM})\end{array}$ & $\begin{array}{c}\text { \% Non- } \\
\text { specific binding }\end{array}$ \\
\hline 0 & $194 \pm 9$ & $208 \pm 8$ & 93 \\
\hline 25 & $876 \pm 44$ & $952 \pm 131$ & 92 \\
\hline 50 & $785 \pm 127$ & $1029 \pm 123$ & 76 \\
\hline 100 & $784 \pm 63$ & $1325 \pm 55$ & 59 \\
\hline
\end{tabular}




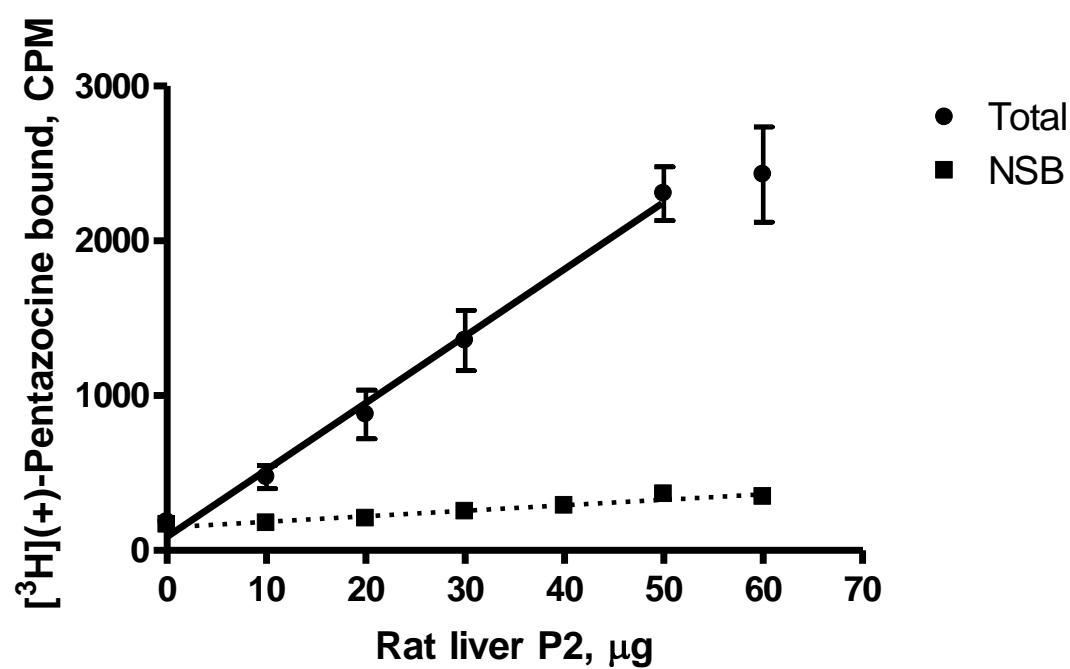

Figure 1. Binding linearity for $\sigma 1$ receptors in rat liver P2 membranes labeled with $5 \mathrm{nM}$ $\left[{ }^{3} \mathrm{H}\right](+)$-pentazocine. Non-specific binding (NSB) was determined by the addition of $10 \mu \mathrm{M}$ haloperidol. Data points represent the mean \pm SEM of three determinations at each protein concentration. The data point at $60 \mu \mathrm{g}$ total protein corresponds to the point at which the data deviates from linearity. 


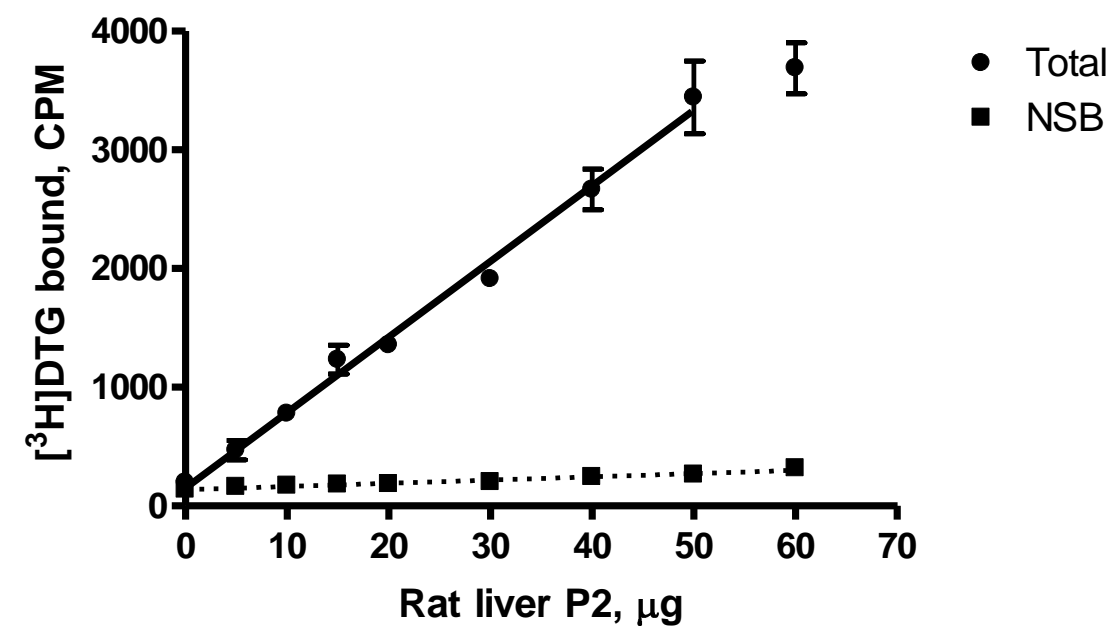

Figure 2. Binding linearity for $\sigma 2$ receptors in rat liver P2 membranes labeled with $5 \mathrm{nM}$ $\left[{ }^{3} \mathrm{H}\right]$ DTG with $300 \mathrm{nM}(+)$-pentazocine. Non-specific binding (NSB) was determined by the addition of $10 \mu \mathrm{M}$ haloperidol. Data points represent the mean \pm SEM of three determinations at each protein concentration. The data point at $60 \mu \mathrm{g}$ total protein corresponds to the point at which the data deviates from linearity. 
Table 2. Binding affinities of reference ligands at $\sigma 1$ receptors.

\begin{tabular}{|c|c|c|c|}
\hline \multirow{2}{*}{ Compound } & \multirow{3}{*}{$\mathrm{K}_{\mathrm{i}}$ at $\sigma 1(\mathrm{nM})$} \\
\cline { 2 - 4 } & Literature & \multicolumn{2}{|c|}{ Experimental } \\
\cline { 2 - 4 } & & Brain/Brandel & Liver/96-well \\
\hline (+)-pentazocine & $6.7 \pm 1.2^{\mathrm{a}}$ & $8.65 \pm 0.4$ & $13.3 \pm 1.8$ \\
\hline (-)-pentazocine & $44.0 \pm 1.2^{\mathrm{a}}$ & $57.2 \pm 1.9$ & $47.6 \pm 3.8$ \\
\hline (+)-SKF10,047 & $28.7 \pm 2.8^{\mathrm{a}}$ & $287 \pm 36$ & $288 \pm 24$ \\
\hline DTG & $74.3 \pm 13.9^{\mathrm{a}}$ & $57.4 \pm 3.3$ & $55.9 \pm 3.9$ \\
\hline haloperidol & $1.9 \pm 0.3^{\mathrm{a}}$ & $3.9 \pm 0.5$ & $3.3 \pm 0.6$ \\
\hline NE100 & $1.54 \pm 0.26^{\mathrm{b}}$ & $2.8 \pm 0.5$ & $2.0 \pm 0.5$ \\
\hline BD1063 & $9.15 \pm 1.28^{\mathrm{c}}$ & $15.0 \pm 2.1$ & $33.4 \pm 4.1$ \\
\hline AC927 & $30 \pm 2^{\mathrm{d}}$ & $61.2 \pm 5.6$ & $74.3 \pm 2.1$ \\
\hline fluvoxamine & $36^{\mathrm{e}}$ & $64.0 \pm 5.2$ & $74.3 \pm 9.4$ \\
\hline progesterone & $338 \pm 8^{\mathrm{f}}$ & $234 \pm 4.4$ & $99.7 \pm 3.1$ \\
\hline dextromethorphan & $652 \pm 33^{\mathrm{g}}$ & $403 \pm 22$ & $214 \pm 15$ \\
\hline rimcazole & $867 \pm 185^{\mathrm{g}}$ & $2565 \pm 36$ & $594 \pm 61$ \\
\hline SN56 & $0.56^{\mathrm{h}}$ & $1.7 \pm 0.1$ & $1.6 \pm 0.1$ \\
\hline
\end{tabular}

$\mathrm{NR}=$ not reported

${ }^{\mathrm{a} B}$ Bowen, 1993. Rat brain P2 with $5 \mathrm{nM}\left[{ }^{3} \mathrm{H}\right](+)$-pentazocine for $\sigma 1$ and $3 \mathrm{nM}\left[{ }^{3} \mathrm{H}\right] \mathrm{DTG}$ with $1 \mu \mathrm{M}$ dextrallorphan for $\sigma 2$.

${ }^{\mathrm{b}}$ Chaki, 1994. Guinea-pig brain. Note: reported value is IC50.

${ }^{\mathrm{c}}$ Matsumoto, 1995. Guinea-pig brain P2 with $3 \mathrm{nM}\left[{ }^{3} \mathrm{H}\right](+)$-pentazocine for $\sigma 1$. Rat liver P2 with $3 \mathrm{nM}\left[{ }^{3} \mathrm{H}\right] \mathrm{DTG}$ with $1 \mu \mathrm{M}$ dextrallorphan for $\sigma 2$.

${ }^{\mathrm{d}}$ Matsumoto, 2008. Rat brain P2 with $3 \mathrm{nM}\left[{ }^{3} \mathrm{H}\right](+)$-pentazocine for $\sigma 1$ and $3 \mathrm{nM}\left[{ }^{3} \mathrm{H}\right] \mathrm{DTG}$ with $300 \mathrm{nM}(+)$-pentazocine for $\sigma 2$.

${ }^{\mathrm{e}}$ Narita, 1996. Rat brain P1/P2 with $5 \mathrm{nM}\left[{ }^{3} \mathrm{H}\right](+)$-pentazocine for $\sigma 1$ and $5 \mathrm{nM}\left[{ }^{3} \mathrm{H}\right] \mathrm{DTG}$ with $1 \mu \mathrm{M}(+)$-pentazocine for $\sigma 2$.

${ }^{\mathrm{f}}$ Hanner, 1996. Guinea-pig brain P3 with 0.3-0.5 nM [ $\left.{ }^{3} \mathrm{H}\right](+)$-pentazocine.

${ }^{\mathrm{g}} \mathrm{Klouz}, 2002$. Rat brain P2/P3, described as "synaptosomal" with 2-3 nM [ $\left.{ }^{3} \mathrm{H}\right](+)$-pentazocine.

${ }^{\text {h}}$ Yous, 2005. Guinea-pig brain P2 with $3 \mathrm{nM}\left[{ }^{3} \mathrm{H}\right](+)$-pentazocine for $\sigma 1$ and $3 \mathrm{nM}\left[{ }^{3} \mathrm{H}\right] \mathrm{DTG}$ with $100 \mathrm{nM}(+)$-normetazocine for $\sigma 2$. 
Table 3. Binding affinities of reference ligands at $\sigma 2$ receptors.

\begin{tabular}{|c|c|c|c|}
\hline \multirow{2}{*}{ Compound } & \multirow{3}{*}{$\mathrm{K}_{\mathrm{i}}$ at $\sigma 2(\mathrm{nM})$} \\
\cline { 2 - 4 } & Literature & \multicolumn{2}{|c|}{ Experimental } \\
\cline { 2 - 4 } & & Brain/Brandel & Liver/96-well \\
\hline (+)-pentazocine & $1361 \pm 134^{\mathrm{a}}$ & $1414 \pm 207$ & $1067 \pm 94$ \\
\hline (-)-pentazocine & $108 \pm 6^{\mathrm{a}}$ & $108 \pm 4.4$ & $58.1 \pm 4.0$ \\
\hline (+)-SKF10,047 & $33,654 \pm 9,409^{\mathrm{a}}$ & $\mathrm{ND}$ & $>10,000$ \\
\hline DTG & $61.2 \pm 13.4^{\mathrm{a}}$ & $43.3 \pm 0.6$ & $24.0 \pm 2.3$ \\
\hline haloperidol & $79.8 \pm 20.6^{\mathrm{a}}$ & $155 \pm 2$ & $57.2 \pm 2.4$ \\
\hline NE100 & $84.6 \pm 32.9^{\mathrm{b}}$ & $95.5 \pm 1.0$ & $36.2 \pm 1.1$ \\
\hline BD1063 & $449 \pm 11^{\mathrm{c}}$ & $928 \pm 40$ & $462 \pm 10.4$ \\
\hline AC927 & $138 \pm 18^{\mathrm{d}}$ & $384 \pm 34$ & $94.3 \pm 3.1$ \\
\hline fluvoxamine & $8439^{\mathrm{e}}$ & $4818 \pm 204$ & $2254 \pm 206$ \\
\hline progesterone & $\mathrm{NR}$ & $>10,000$ & $>10,000$ \\
\hline dextromethorphan & $\mathrm{NR}$ & $>10,000$ & $>10,000$ \\
\hline rimcazole & $\mathrm{NR}$ & $1568 \pm 154$ & $719 \pm 72$ \\
\hline SN56 & $1000^{\mathrm{h}}$ & $627 \pm 115$ & $248 \pm 15$ \\
\hline
\end{tabular}

$\mathrm{NR}=$ not reported.

${ }^{\mathrm{a} B}$ Bowen, 1993. Rat brain P2 with $5 \mathrm{nM}\left[{ }^{3} \mathrm{H}\right](+)$-pentazocine for $\sigma 1$ and $3 \mathrm{nM}\left[{ }^{3} \mathrm{H}\right] \mathrm{DTG}$ with $1 \mu \mathrm{M}$ dextrallorphan for $\sigma 2$.

${ }^{\mathrm{b}}$ Chaki, 1994. Guinea-pig brain. Note: reported value is IC50.

${ }^{\mathrm{c}}$ Matsumoto, 1995. Guinea-pig brain P2 with $3 \mathrm{nM}\left[{ }^{3} \mathrm{H}\right](+)$-pentazocine for $\sigma 1$. Rat liver P2 with $3 \mathrm{nM}\left[{ }^{3} \mathrm{H}\right] \mathrm{DTG}$ with $1 \mu \mathrm{M}$ dextrallorphan for $\sigma 2$.

${ }^{\mathrm{d}}$ Matsumoto, 2008. Rat brain P2 with $3 \mathrm{nM}\left[{ }^{3} \mathrm{H}\right](+)$-pentazocine for $\sigma 1$ and $3 \mathrm{nM}\left[{ }^{3} \mathrm{H}\right] \mathrm{DTG}$ with $300 \mathrm{nM}(+)$-pentazocine for $\sigma 2$.

${ }^{\mathrm{e}}$ Narita, 1996. Rat brain P1/P2 with $5 \mathrm{nM}\left[{ }^{3} \mathrm{H}\right](+)$-pentazocine for $\sigma 1$ and $5 \mathrm{nM}\left[{ }^{3} \mathrm{H}\right] \mathrm{DTG}$ with $1 \mu \mathrm{M}(+)$-pentazocine for $\sigma 2$.

${ }^{\mathrm{f}}$ Hanner, 1996. Guinea-pig brain P3 with 0.3-0.5 nM [ $\left.{ }^{3} \mathrm{H}\right](+)$-pentazocine.

${ }^{\mathrm{g}} \mathrm{Klouz}, 2002$. Rat brain P2/P3, described as "synaptosomal" with 2-3 nM [ $\left.{ }^{3} \mathrm{H}\right](+)$-pentazocine.

${ }^{\text {h}}$ Yous, 2005. Guinea-pig brain P2 with $3 \mathrm{nM}\left[{ }^{3} \mathrm{H}\right](+)$-pentazocine for $\sigma 1$ and $3 \mathrm{nM}\left[{ }^{3} \mathrm{H}\right] \mathrm{DTG}$ with $100 \mathrm{nM}(+)$-normetazocine for $\sigma 2$. 
A

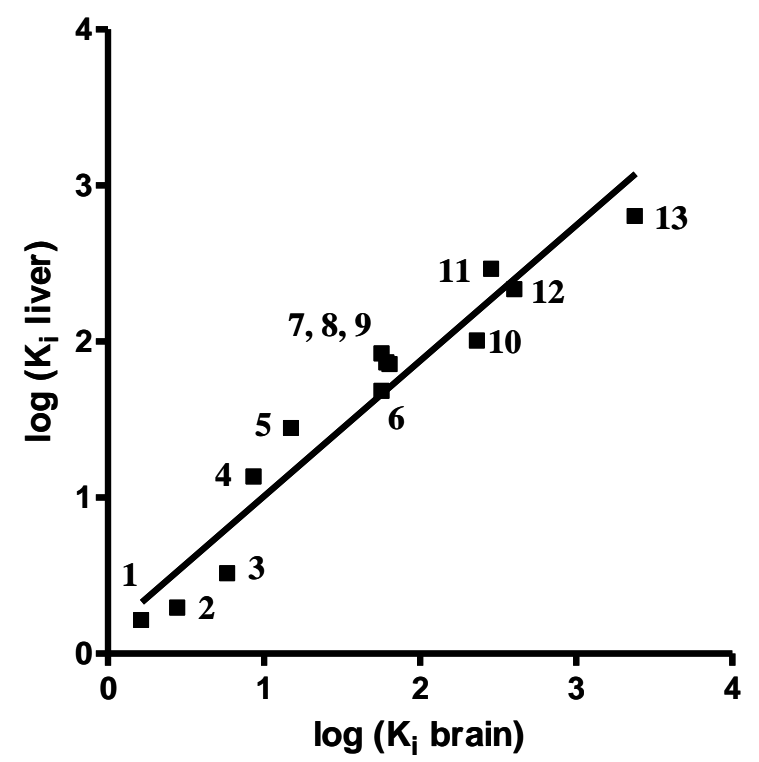

B

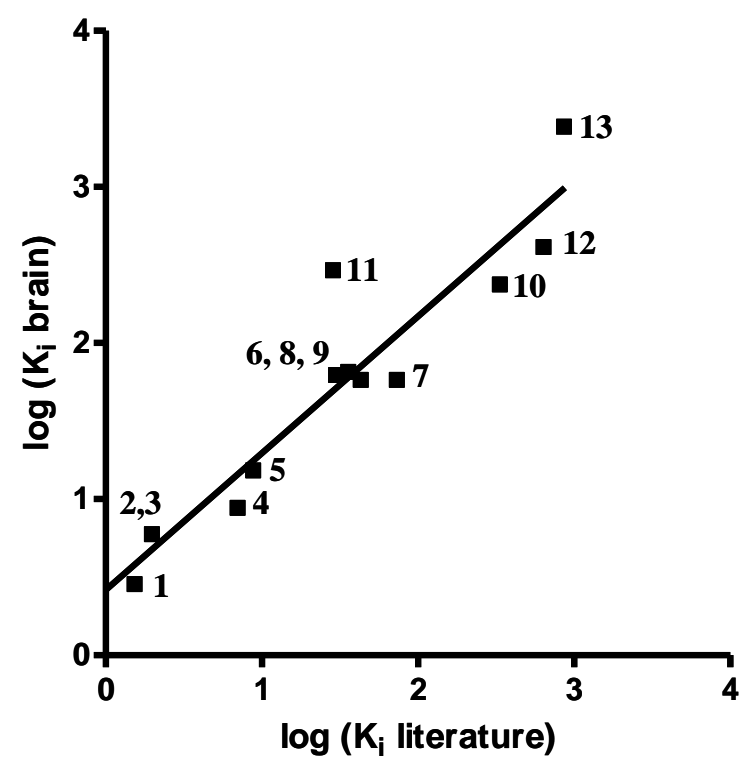

Figure 3. Correlation plots for binding of sigma reference ligands to $\sigma 1$ receptors in (A) rat liver P2 versus rat brain P2 membranes, and (B) rat brain P2 versus literature values determined in rat or guineapig brain membranes. Plots show least squares regression line. Correlation plots yielded Pearson $\mathrm{r}$ values $=0.97$ and 0.95 for plot A and B, respectively. [1, SN56; 2, NE100; 3, haloperidol; 4, (+)-pentazocine; 5 , BD1063; 6, (-)-pentazocine; 7, DTG; 8, AC927; 9, fluvoxamine; 10, progesterone; 11, (+)-SKF10,047; 12, dextromethorphan; 13, rimcazole]. 
A

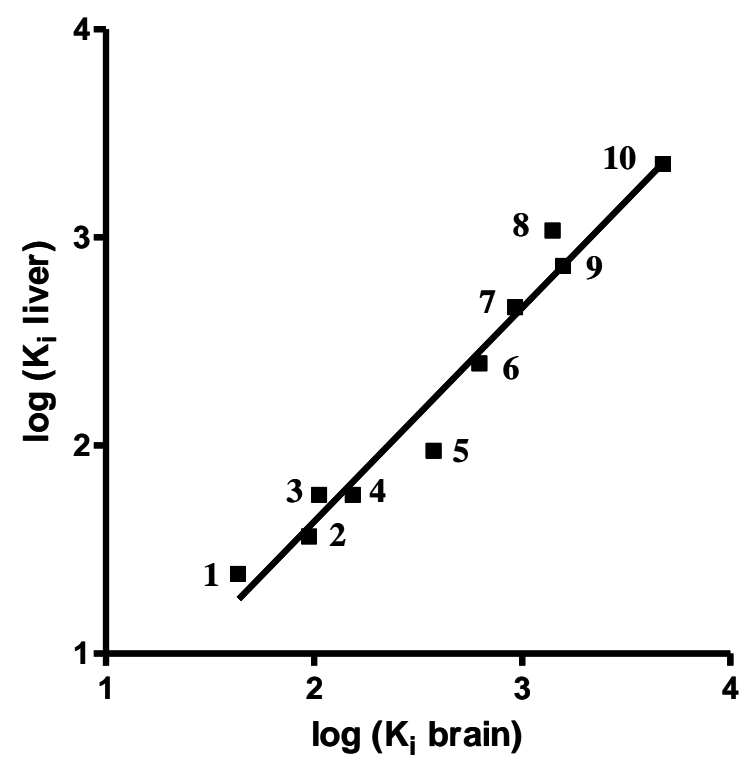

B

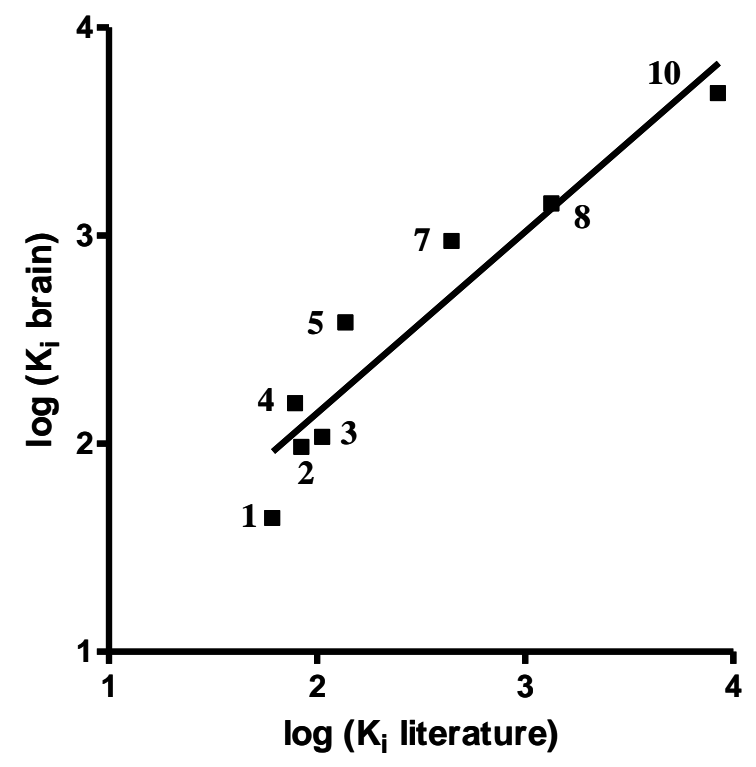

Figure 4. Correlation plots for binding of sigma reference ligands to $\sigma 2$ receptors in (A) rat liver P2 versus rat brain P2 membranes, (B) rat brain P2 versus literature values determined in rat or guinea-pig brain membranes. Plots show least squares regression line. Correlation plots yielded Pearson $\mathrm{r}$ values $=$ 0.98, and 0.95 for plot A and B respectively. [1, DTG; 2, NE100; 3, (-)-pentazocine; 4, haloperidol; 5, AC927; 6, SN56; 7, BD1063; 8, (+)-pentazocine; 9, rimcazole 10, fluvoxamine]. 
Table 4. Binding affinities for 2(3H)-benzothiazolone compounds for sigma receptors in rat liver P2 membranes. Linker length (n) and ring size (m) refer to the structure shown in Figure 5.

\begin{tabular}{|c|c|c|c|c|c|c|}
\hline \multirow{2}{*}{ Compound } & \multirow{2}{*}{$\mathrm{R}$} & \multirow{2}{*}{$\begin{array}{c}\text { Linker } \\
\text { length, } n\end{array}$} & \multirow{2}{*}{ Ring size, $\mathrm{m}$} & \multicolumn{2}{|c|}{$\mathrm{K}_{\mathrm{i}}(\mathrm{nM})$} & \multirow{2}{*}{$\mathrm{K}_{\mathrm{i}} \sigma 2 / \mathrm{K}_{\mathrm{i}} \sigma 1$} \\
\hline & & & & $\sigma 1$ & $\sigma 2$ & \\
\hline RB65 & \multirow{6}{*}{$-\mathrm{H}$} & 1 & 0 & $578 \pm 41$ & $8264 \pm 500$ & 14 \\
\hline RB67 & & 1 & 3 & $9.7 \pm 0.6$ & $716 \pm 30$ & 74 \\
\hline RB2 & & 2 & 2 & $4.1 \pm 0.3$ & $177 \pm 26$ & 43 \\
\hline RB4 & & 3 & 2 & $3.2 \pm 0.02$ & $101 \pm 14$ & 31 \\
\hline RB6 & & 4 & 2 & $7.0 \pm 0.3$ & $2.5 \pm 0.3$ & 0.4 \\
\hline RB8 & & 5 & 2 & $7.5 \pm 0.6$ & $2.4 \pm 0.4$ & 0.3 \\
\hline SN56 & \multirow{5}{*}{$-\left(\mathrm{CH}_{2}\right)_{2} \mathrm{CH}_{3}$} & 1 & 2 & $1.6 \pm 0.1$ & $270 \pm 4.7$ & 168 \\
\hline RB10 & & 2 & 2 & $1.4 \pm 0.1$ & $17.2 \pm 1.0$ & 13 \\
\hline RB14 & & 3 & 2 & $6.1 \pm 1.2$ & $4.3 \pm 0.3$ & 0.7 \\
\hline RB16 & & 4 & 2 & $4.6 \pm 0.4$ & $1.6 \pm 0.1$ & 0.3 \\
\hline RB18 & & 5 & 2 & $6.3 \pm 0.9$ & $2.3 \pm 0.2$ & 0.4 \\
\hline RB20 & \multirow{3}{*}{$-\left(\mathrm{CH}_{2}\right)_{3} \mathrm{CH}_{3}$} & 2 & 2 & $2.2 \pm 0.4$ & $15.3 \pm 0.9$ & 7 \\
\hline RB34 & & 3 & 2 & $1.9 \pm 0.2$ & $4.4 \pm 0.3$ & 2.4 \\
\hline RB24 & & 5 & 2 & $12.0 \pm 0.7$ & $4.1 \pm 0.6$ & 0.3 \\
\hline RB75 & \multirow{6}{*}{$-\mathrm{COCH}_{2} \mathrm{CH}_{3}$} & 1 & 0 & $116 \pm 15$ & $4787 \pm 101$ & 41 \\
\hline RB74 & & 1 & 2 & $4.5 \pm 0.2$ & $2181 \pm 127$ & 483 \\
\hline RB26 & & 2 & 2 & $3.7 \pm 0.3$ & $305 \pm 7.0$ & 83 \\
\hline RB28 & & 3 & 2 & $10.3 \pm 0.9$ & $30.3 \pm 2.0$ & 3.0 \\
\hline RB30 & & 4 & 2 & $12.2 \pm 1.1$ & $8.3 \pm 0.8$ & 0.7 \\
\hline RB32 & & 5 & 2 & $10.4 \pm 0.1$ & $1.1 \pm 0.1$ & 0.1 \\
\hline RB36 & \multirow{4}{*}{$-\mathrm{CO}\left(\mathrm{CH}_{2}\right)_{2} \mathrm{CH}_{3}$} & 2 & 2 & $2.6 \pm 0.4$ & $104 \pm 1.9$ & 39 \\
\hline RB38 & & 3 & 2 & $4.8 \pm 0.1$ & $21.6 \pm 4.2$ & 5 \\
\hline RB40 & & 4 & 2 & $16.3 \pm 0.6$ & $5.7 \pm 0.5$ & 0.4 \\
\hline RB70 & & 5 & 2 & $10.8 \pm 0.4$ & $2.3 \pm 0.3$ & 0.2 \\
\hline
\end{tabular}




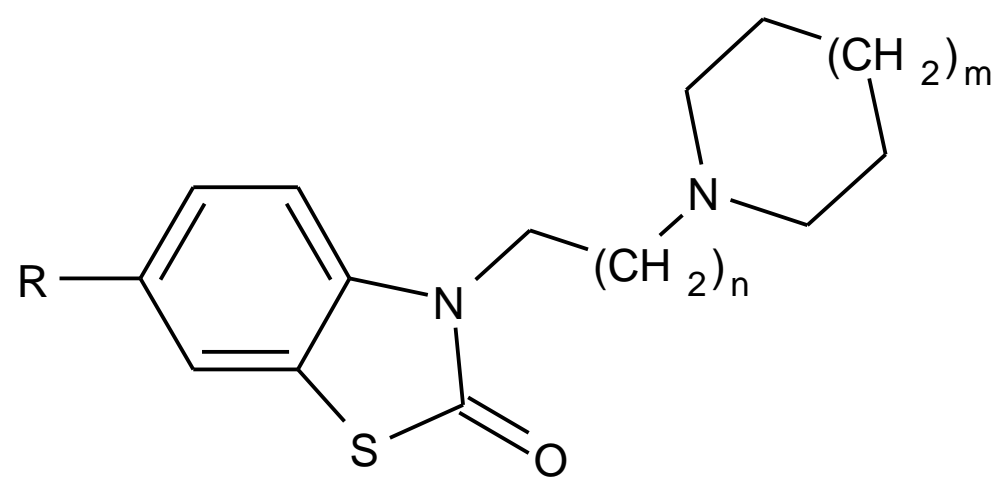

Figure 5. Structure of 2(3H)-benzothiazolone analogs. $\mathrm{R}=\mathrm{H},\left(\mathrm{CH}_{2}\right)_{2} \mathrm{CH}_{3},\left(\mathrm{CH}_{2}\right)_{3} \mathrm{CH}_{3}, \mathrm{COCH}_{2} \mathrm{CH}_{3}$, or $\mathrm{CO}\left(\mathrm{CH}_{2}\right)_{2} \mathrm{CH}_{3}$. 
Table 5. Lipophilicity expressed as $\log \mathrm{D}$ calculated at $\mathrm{pH} 8$ for 2(3H)-benzothiazolone compounds.

\begin{tabular}{|c|c|c|c|c|c|}
\hline Compound & $\mathrm{R}$ & $\begin{array}{c}\text { Linker length, } \\
\mathrm{n}\end{array}$ & Ring size, $\mathrm{m}$ & $\mathrm{K}_{\mathrm{i}} \sigma 2(\mathrm{nM})$ & $\log \mathrm{D}, \mathrm{pH} 8.0$ \\
\hline RB65 & \multirow{6}{*}{$-\mathrm{H}$} & 1 & 0 & 8264 & 0.93 \\
\hline RB67 & & 1 & 3 & 716 & 2.92 \\
\hline RB2 & & 2 & 2 & 177 & 1.52 \\
\hline RB4 & & 3 & 2 & 101 & 1.47 \\
\hline RB6 & & 4 & 2 & 2.5 & 1.63 \\
\hline RB8 & & 5 & 2 & 2.4 & 1.92 \\
\hline SN56 & \multirow{5}{*}{$-\left(\mathrm{CH}_{2}\right)_{2} \mathrm{CH}_{3}$} & 1 & 2 & 270 & 3.34 \\
\hline RB10 & & 2 & 2 & 17.2 & 2.82 \\
\hline RB14 & & 3 & 2 & 4.3 & 2.6 \\
\hline RB16 & & 4 & 2 & 1.6 & 2.64 \\
\hline RB18 & & 5 & 2 & 2.3 & 2.96 \\
\hline RB20 & \multirow{3}{*}{$-\left(\mathrm{CH}_{2}\right)_{3} \mathrm{CH}_{3}$} & 2 & 2 & 15.3 & 3.14 \\
\hline RB34 & & 3 & 2 & 4.4 & 2.94 \\
\hline RB24 & & 5 & 2 & 4.1 & 3.43 \\
\hline RB75 & \multirow{6}{*}{$-\mathrm{COCH}_{2} \mathrm{CH}_{3}$} & 1 & 0 & 4787 & 1.36 \\
\hline RB74 & & 1 & 2 & 2181 & 2.8 \\
\hline RB26 & & 2 & 2 & 305 & 2.23 \\
\hline $\mathrm{RB} 28$ & & 3 & 2 & 30.3 & 2.16 \\
\hline RB30 & & 4 & 2 & 8.3 & 1.7 \\
\hline RB32 & & 5 & 2 & 1.1 & 2.37 \\
\hline RB36 & \multirow{4}{*}{$-\mathrm{CO}\left(\mathrm{CH}_{2}\right)_{2} \mathrm{CH}_{3}$} & 2 & 2 & 104 & 2.72 \\
\hline RB38 & & 3 & 2 & 21.6 & 2.25 \\
\hline RB40 & & 4 & 2 & 5.7 & 2.47 \\
\hline RB70 & & 5 & 2 & 2.3 & 2.67 \\
\hline
\end{tabular}


A

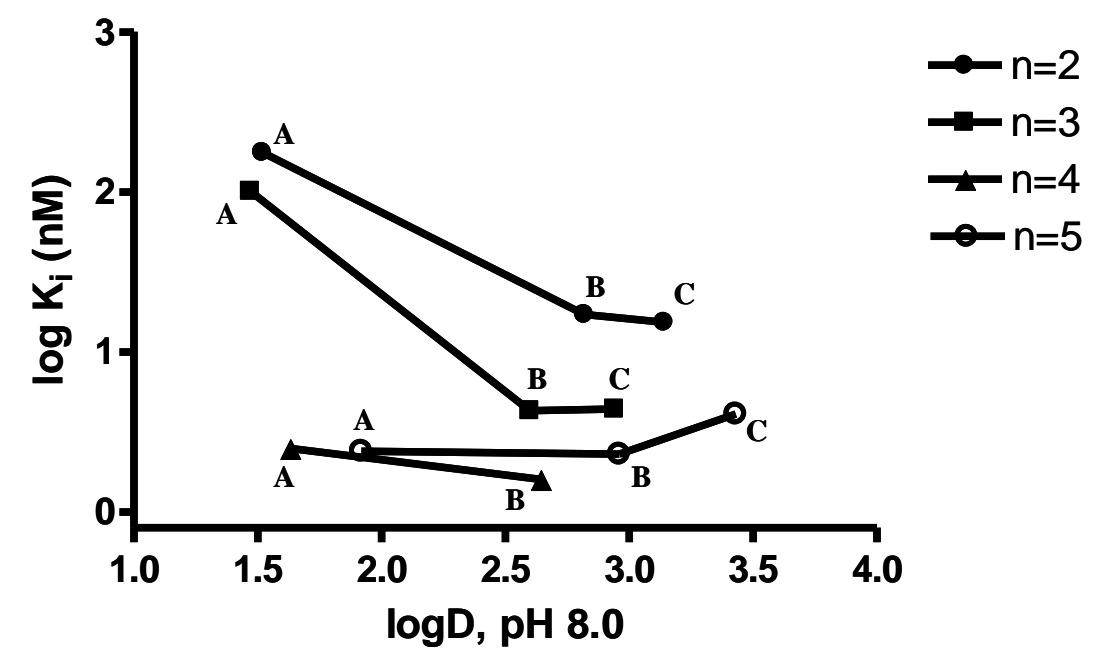

B

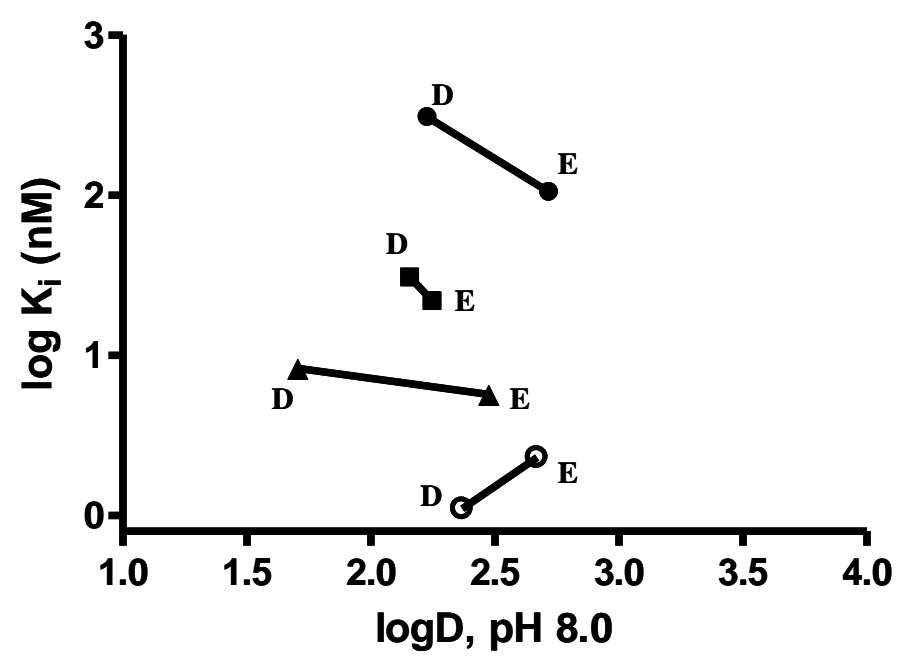

Figure 6. Binding affinity at $\sigma 2$ receptor $\left(\mathrm{K}_{\mathrm{i}} \sigma 2\right)$ versus lipophilicity $(\log \mathrm{D})$ calculated at $\mathrm{pH}=8$ for homologous $2(3 \mathrm{H})$-benzothiazolone compounds. The $\mathrm{n}$ in the legend denotes the linker chain length. (A) $\mathrm{A} ; \mathrm{R}=-\mathrm{H}, \mathrm{B} ; \mathrm{R}=-\mathrm{CH}_{2} \mathrm{CH}_{3}, \mathrm{C} ; \mathrm{R}=-\left(\mathrm{CH}_{2}\right)_{2} \mathrm{CH}_{3}$. (B) $\mathrm{D} ; \mathrm{R}=-\mathrm{OCH}_{2} \mathrm{CH}_{3}, \mathrm{E} ; \mathrm{R}=-$ $\mathrm{O}\left(\mathrm{CH}_{2}\right)_{2} \mathrm{CH}_{3}$. 


\subsection{References}

1. Martin, W.R., et al., The effects of morphine- and nalorphine- like drugs in the nondependent and morphine-dependent chronic spinal dog. J Pharmacol Exp Ther, 1976. 197(3): p. 517-32.

2. Tam, S.W., Naloxone-inaccessible sigma receptor in rat central nervous system. Proc Natl Acad Sci U S A, 1983. 80(21): p. 6703-7.

3. Su, T.P., Evidence for sigma opioid receptor: binding of [3H]SKF-10047 to etorphineinaccessible sites in guinea-pig brain. J Pharmacol Exp Ther, 1982. 223(2): p. 284-90.

4. Maurice, T. and T.P. Su, The pharmacology of sigma-1 receptors. Pharmacol Ther, 2009. 124(2): p. 195-206.

5. Hashimoto, K. and K. Ishiwata, Sigma receptor ligands: possible application as therapeutic drugs and as radiopharmaceuticals. Curr Pharm Des, 2006. 12(30): p. 385776.

6. Mach, R.H. and K.T. Wheeler, Development of molecular probes for imaging sigma-2 receptors in vitro and in vivo. Cent Nerv Syst Agents Med Chem, 2009. 9(3): p. 230-45.

7. Cobos, E.J., et al., Pharmacology and therapeutic potential of sigma(1) receptor ligands. Curr Neuropharmacol, 2008. 6(4): p. 344-66.

8. Sakata, M., et al., Mapping of human cerebral sigmal receptors using positron emission tomography and [11C]SA4503. Neuroimage, 2007. 35(1): p. 1-8.

9. Tu, Z., et al., Synthesis and in Vitro and in Vivo Evaluation of (18)F-Labeled Positron Emission Tomography (PET) Ligands for Imaging the Vesicular Acetylcholine Transporter. J Med Chem, 2009. 52(5): p. 1358-69.

10. Maestrup, E.G., et al., Synthesis, pharmacological activity and structure affinity relationships of spirocyclic sigma(1) receptor ligands with a (2-fluoroethyl) residue in 3position. Bioorg Med Chem, 2011. 19(1): p. 393-405. 
11. Xu, J., et al., [3H]N-[4-(3,4-dihydro-6,7-dimethoxyisoquinolin-2(1H)-yl)butyl]-2methoxy-5 -methylbenzamide: a novel sigma-2 receptor probe. Eur J Pharmacol, 2005. 525(1-3): p. 8-17.

12. Tu, Z., et al., Radiosynthesis and biological evaluation of a promising sigma(2)-receptor ligand radiolabeled with fluorine-18 or iodine-125 as a PET/SPECT probe for imaging breast cancer. Appl Radiat Isot, 2010. 68(12): p. 2268-73.

13. Chu, W., et al., New N-substituted 9-azabicyclo[3.3.1]nonan-3alpha-yl phenylcarbamate analogs as sigma2 receptor ligands: synthesis, in vitro characterization, and evaluation as PET imaging and chemosensitization agents. Bioorg Med Chem, 2009. 17(3): p. 122231.

14. Vangveravong, S., et al., Synthesis of N-substituted 9-azabicyclo[3.3.1]nonan-3alpha-yl carbamate analogs as sigma2 receptor ligands. Bioorg Med Chem, 2006. 14(20): p. 6988-97.

15. Abate, C., et al., Analogues of sigma Receptor Ligand 1-Cyclohexyl-4-[3-(5-methoxy1,2,3,4-tetrahydronaphthalen-1-yl)propyl]pipe razine (PB28) with Added Polar Functionality and Reduced Lipophilicity for Potential Use as Positron Emission Tomography Radiotracers. J Med Chem, 2011. 54(4): p. 1022-32.

16. Nahas, R.I., J.R. Lever, and S.Z. Lever, Synthesis and structure-activity relationships of $N$-(3-phenylpropyl)-N'-benzylpiperazines: Potent ligands for sigmal and sigma2 receptors. Bioorg Med Chem, 2008. 16(2): p. 755-61.

17. Nguyen, E.C., et al., Involvement of sigma (sigma) receptors in the acute actions of methamphetamine: receptor binding and behavioral studies. Neuropharmacology, 2005. 49(5): p. 638-45.

18. Matsumoto, R.R., et al., Rimcazole analogs attenuate the convulsive effects of cocaine: correlation with binding to sigma receptors rather than dopamine transporters. Neuropharmacology, 2001. 41(7): p. 878-86. 
19. DeHaven-Hudkins, D.L., L.C. Fleissner, and F.Y. Ford-Rice, Characterization of the binding of $[3 \mathrm{H}](+)$-pentazocine to sigma recognition sites in guinea pig brain. Eur $\mathrm{J}$ Pharmacol, 1992. 227(4): p. 371-8.

20. Bowen, W.D., et al., [3H]-(+)-Pentazocine: a potent and highly selective benzomorphanbased probe for sigma-1 receptors. Molecular Pharmacology, 1993. 1(3): p. 117-126.

21. Nguyen, V.H., et al., Comparison of binding parameters of sigma 1 and sigma 2 binding sites in rat and guinea pig brain membranes: novel subtype-selective trishomocubanes. Eur J Pharmacol, 1996. 311(2-3): p. 233-40.

22. Hellewell, S.B. and W.D. Bowen, A sigma-like binding site in rat pheochromocytoma (PC12) cells: decreased affinity for (+)-benzomorphans and lower molecular weight suggest a different sigma receptor form from that of guinea pig brain. Brain Res, 1990. 527(2): p. 244-53.

23. Hellewell, S.B., et al., Rat liver and kidney contain high densities of sigma 1 and sigma 2 receptors: characterization by ligand binding and photoaffinity labeling. Eur J Pharmacol, 1994. 268(1): p. 9-18.

24. Gattu, M., A.V. Terry, Jr., and J.J. Buccafusco, A rapid microtechnique for the estimation of muscarinic and nicotinic receptor binding parameters using 96-well filtration plates. $\mathrm{J}$ Neurosci Methods, 1995. 63(1-2): p. 121-25.

25. Hillard, C.J., W.S. Edgemond, and W.B. Campbell, Characterization of ligand binding to the cannabinoid receptor of rat brain membranes using a novel method: application to anandamide. J Neurochem, 1995. 64(2): p. 677-83.

26. Van Der Hee, R.M., et al., Comparison of 3 AT1 receptor binding assays: filtration assay, ScreenReady Target, and WGA Flashplate. J Biomol Screen, 2005. 10(2): p. 11826.

27. DeHaven-Hudkins, D.L., et al., sigma recognition sites in brain and peripheral tissues. Characterization and effects of cytochrome P450 inhibitors. Biochem Pharmacol, 1994. 47(7): p. 1231-9. 
28. Hanner, M., et al., Purification, molecular cloning, and expression of the mammalian sigmal-binding site. Proc Natl Acad Sci U S A, 1996. 93(15): p. 8072-7.

29. Klouz, A., et al., Evidence for sigma-1-like receptors in isolated rat liver mitochondrial membranes. Br J Pharmacol, 2002. 135(7): p. 1607-15.

30. Klouz, A., et al., [3H]BHDP as a novel and selective ligand for sigmal receptors in liver mitochondria and brain synaptosomes of the rat. FEBS Lett, 2003. 553(1-2): p. 157-62.

31. Quirion, R., et al., A proposal for the classification of sigma binding sites. Trends Pharmacol Sci, 1992. 13(3): p. 85-6.

32. Lutzke, B.S. and J.M. Braughler, An improved method for the identification and quantitation of biological lipids by HPLC using laser light-scattering detection. J Lipid Res, 1990. 31(11): p. 2127-30.

33. Gebreselassie, D. and W.D. Bowen, Sigma-2 receptors are specifically localized to lipid rafts in rat liver membranes. Eur J Pharmacol, 2004. 493(1-3): p. 19-28.

34. Torrence-Campbell, C. and W.D. Bowen, Differential solubilization of rat liver sigma 1 and sigma 2 receptors: retention of sigma 2 sites in particulate fractions. Eur $\mathbf{J}$ Pharmacol, 1996. 304(1-3): p. 201-10.

35. Fan, K.H., J.R. Lever, and S.Z. Lever, Effect of structural modification in the amine portion of substituted aminobutyl-benzamides as ligands for binding sigma(1) and sigma(2) receptors. Bioorg Med Chem, 2011. 19(6): p. 1852-9.

36. Garces-Ramirez, L., et al., Sigma receptor agonists: receptor binding and effects on mesolimbic dopamine neurotransmission assessed by microdialysis. Biol Psychiatry, 2011. 69(3): p. 208-17.

37. Pham, T.Q., et al., Synthesis and evaluation of novel radioiodinated benzamides for malignant melanoma. J Med Chem, 2007. 50(15): p. 3561-72. 
38. $\mathrm{Xu}, \mathrm{R} ., \mathrm{J} . \mathrm{R}$. Lever, and S.Z. Lever, Synthesis and in vitro evaluation of tetrahydroisoquinolinyl benzamides as ligands for sigma receptors. Bioorg Med Chem Lett, 2007. 17(9): p. 2594-7.

39. Ucar, H., et al., 2(3H)-benzoxazolone and 2(3H)-benzothiazolone derivatives: novel, potent and selective sigmal receptor ligands. Eur J Pharmacol, 1997. 335(2-3): p. 26773.

40. Yous, S., et al., Novel 2(3H)-Benzothiazolones as highly potent and selective sigma-1 receptor ligands. Medicinal Chemistry Research, 2005. 14(3): p. 158-168.

41. Fishback, J.A., et al., Synthesis and characterization of [(3)H]-SN56, a novel radioligand for the sigma receptor. Eur J Pharmacol, 2011. 653(1-3): p. 1-7.

42. Matsumoto, R.R., et al., Effects of the selective sigma receptor ligand, 1-(2phenethyl)piperidine oxalate (AC927), on the behavioral and toxic effects of cocaine. Drug Alcohol Depend, 2011.

43. Kaushal, N., et al., Synthesis and Pharmacological Evaluation of 6-Acetyl-3-(4-(4-(4fluorophenyl)piperazin-1-yl)butyl)benzo[d]oxazol-2(3H) -one (SN79), a Cocaine Antagonist, in Rodents. AAPS J, 2011.

44. Menkel, M., et al., Selective sigma ligands block stimulant effects of cocaine. Eur J Pharmacol, 1991. 201(2-3): p. 251-2.

45. Witkin, J.M., et al., Effects of the selective sigma receptor ligand, 6-[6-(4hydroxypiperidinyl)hexyloxy]-3-methylflavone (NPC 16377), on behavioral and toxic effects of cocaine. J Pharmacol Exp Ther, 1993. 266(2): p. 473-82.

46. Matsumoto, R.R., et al., Characterization of two novel sigma receptor ligands: antidystonic effects in rats suggest sigma receptor antagonism. Eur J Pharmacol, 1995. 280(3): p. 301-10.

47. Matsumoto, R.R., et al., Dissociation of the motor effects of (+)-pentazocine from binding to sigma 1 sites. Eur J Pharmacol, 1996. 301(1-3): p. 31-40. 
48. Cheng, Y. and W.H. Prusoff, Relationship between the inhibition constant (K1) and the concentration of inhibitor which causes 50 per cent inhibition (I50) of an enzymatic reaction. Biochem Pharmacol, 1973. 22(23): p. 3099-108.

49. Bylund, D.B. and M.L. Toews, Radioligand binding methods: practical guide and tips. Am J Physiol, 1993. 265(5 Pt 1): p. L421-9.

50. O'Brien, R.A., ed. Receptor Binding in Drug Research. 1st ed. 1986, Marcel Dekker, Inc.

51. Limbird, L.E., Cell surface receptors: A short course on theory and methods. 1st ed. 1986: Springer. .

52. Kekuda, R., et al., Cloning and functional expression of the human type 1 sigma receptor (hSigmaR1). Biochem Biophys Res Commun, 1996. 229(2): p. 553-8.

53. Seth, P., F.H. Leibach, and V. Ganapathy, Cloning and structural analysis of the cDNA and the gene encoding the murine type 1 sigma receptor. Biochem Biophys Res Commun, 1997. 241(2): p. 535-40.

54. Pan, Y.X., et al., Cloning and characterization of a mouse sigmal receptor. $\mathrm{J}$ Neurochem, 1998. 70(6): p. 2279-85.

55. Seth, P., et al., Cloning and functional characterization of a sigma receptor from rat brain. J Neurochem, 1998. 70(3): p. 922-31.

56. Mei, J. and G.W. Pasternak, Molecular cloning and pharmacological characterization of the rat sigmal receptor. Biochem Pharmacol, 2001. 62(3): p. 349-55.

57. McCann, D.J. and T.P. Su, Solubilization and characterization of haloperidol-sensitive (+)-[3H]SKF-10,047 binding sites (sigma sites) from rat liver membranes. $\mathrm{J}$ Pharmacol Exp Ther, 1991. 257(2): p. 547-54. 
58. McCann, D.J., A.D. Weissman, and T.P. Su, Sigma-1 and sigma-2 sites in rat brain: comparison of regional, ontogenetic, and subcellular patterns. Synapse, 1994. 17(3): p. 182-9.

59. Cagnotto, A., A. Bastone, and T. Mennini, $[3 H](+)$-pentazocine binding to rat brain sigma 1 receptors. Eur J Pharmacol, 1994. 266(2): p. 131-8.

60. Ramachandran, S., et al., Purification and characterization of the guinea pig sigma-1 receptor functionally expressed in Escherichia coli. Protein Expr Purif, 2007. 51(2): p. 283-92.

61. Carter, C.M., J.R. Leighton-Davies, and S.J. Charlton, Miniaturized receptor binding assays: complications arising from ligand depletion. J Biomol Screen, 2007. 12(2): p. 255-66.

62. Schepmann, D., et al., Expression of sigma receptors of human urinary bladder tumor cells (RT-4 cells) and development of a competitive receptor binding assay for the determination of ligand affinity to human sigma(2) receptors. J Pharm Biomed Anal, 2011.

63. Lee, I.T., S. Chen, and J.A. Schetz, An unambiguous assay for the cloned human sigmal receptor reveals high affinity interactions with dopamine D4 receptor selective compounds and a distinct structure-affinity relationship for butyrophenones. Eur J Pharmacol, 2008. 578(2-3): p. 123-36.

64. Katoch-Rouse, R., et al., Synthesis, Structure-Activity Relationship, and Evaluation of SR141716 Analogues: Development of Central Cannabinoid Receptor Ligands with Lower Lipophilicity. Journal of Medicinal Chemistry, 2003. 46(4): p. 642-645.

65. Willis, P.G., et al., Synthesis and Structure-Activity Relationship of a Novel Series of Aminoalkylindoles with Potential for Imaging the Neuronal Cannabinoid Receptor by Positron Emission Tomography. Journal of Medicinal Chemistry, 2005. 48(18): p. 58135822. 
66. Berardi, F., et al., Exploring the importance of piperazine $N$-atoms for sigma(2) receptor affinity and activity in a series of analogs of 1-cyclohexyl-4-[3-(5-methoxy-1,2,3,4tetrahydronaphthalen-1-yl)propyl]pipe razine (PB28). J Med Chem, 2009. 52(23): p. 7817-28. 


\section{CHAPTER 4}

\section{A scintillation proximity assay (SPA) for radioligand binding analysis of sigma receptor ligands}




\subsection{Abstract}

Sigma ligands exhibit activity in numerous in vivo and in vitro model systems. In vivo, sigma antagonists can mitigate the toxic and behavioral effects of psychostimulants, while agonists show efficacy in rodent models of depression. Accordingly, sigma receptors represent a promising target for therapeutic development. Because there are no established in vitro functional assays available for routine screening of sigma ligands binding assays are of increased importance. The conventional cell harvester based filtration method used for radioligand binding studies with sigma receptors is a low throughput method. 96-well filtration has been demonstrated to be an improvement over conventional filtration but the scintillation proximity assay (SPA) offers the potential to further increase throughput and improve accuracy and precision due to its homogenous nature. In the present work, preliminary data was generated with SPA, using conventional sigma radioligands in conjunction with rat liver P2 membranes. The studies show that SPA PVT WGA (polyvinyltoluene, wheat germ agglutinin) beads can be used for the analysis of ligand binding at both $\sigma 1$ and $\sigma 2$ receptors. Competition assays with a limited number of reference ligands showed good agreement with results obtained using 96-well filtration for both receptor subtypes. Non-specific binding for $\sigma 1$ receptors labeled with $\left[{ }^{3} \mathrm{H}\right](+)-$ pentazocine was approximately $40 \%$. Assays for $\sigma 2$ receptors had an effective non-specific binding signal of $60 \%$ due in part to the necessity of blocking $\sigma 1$ binding, which accounts for approximately one half of the total specific binding of $\left[{ }^{3} \mathrm{H}\right] \mathrm{DTG}$. The results demonstrate that SPA technologies represent a feasible alternative to currently used filtration based methods for the determination of sigma ligand binding affinities. However, additional studies will be necessary to formally validate this method, and a subtype specific radioligand for $\sigma 2$ receptors may be required to reliably assess $\sigma 2$ binding using SPA. 


\subsection{Introduction}

Radioligand binding continues to serve as a primary screen for new sigma receptor ligands because there are no medium or high throughput in vitro assays for sigma receptor activity. The scintillation proximity assay (SPA) is a relatively new technology that is designed for use in enzymatic and radioligand binding assays. SPA utilizes microscopic beads that produce photons when radiolabeled molecules are in close proximity to the bead surface. SPA beads for radioligand binding assays exploit the interaction of glycosylation sites on cell membranes and bead bound wheat germ agglutinin (WGA), or charge interactions between cell membranes and bead bound polylysine, that localize membrane-bound receptors close to the bead surface [1-3]. The subsequent binding of radioligands to the bead associated membrane-bound receptors gives rise to a signal commensurate with the amount of bound radioligand [1-3].

Conventional filtration-based binding assays are tedious, time consuming, and generate a significant amount of radioactive waste. In SPA all the assay components are combined and read in a single assay plate, resulting in less than $25 \mathrm{ml}$ of mixed radioactive waste per 96 samples, compared to the $\sim 11$ of aqueous radioactive waste and $300-500 \mathrm{ml}$ of mixed scintillation fluidradioactive waste that are generated during processing of 96 samples using a conventional Brandel cell harvester. In addition to reductions in waste, the reduced number of manipulations and the elimination of the filtration step in SPA results in increased accuracy and precision relative to filtration assays [1-4]. Additionally, because SPA can also be performed in 384 and 1536 well plates the method is amenable to use in high throughput screening (HTS) [1, 4-6].

SPA assays have been reported for a number of classical membrane bound receptors including serotonin, acetylcholine, and opioid receptor subtypes [7-9]; application of the SPA technology to the analysis of sigma receptor binding has not been reported. Four of the five SPA bead types designed for radioligand binding experiments rely on capture of membranes via interactions of wheat germ agglutinin (WGA) on the bead surface and N-acetyl- $\beta$-D-glucosaminyl residues of glycoproteins [1-3]. Because sigma receptors normally reside subcellularly [10] and the P2 fraction that is typically used for sigma receptor binding experiments consists largely of mitochondria and the mitochondrial associated membrane (MAM) [11, 12] it was not known if 
WGA binding competent moieties were present in this membrane preparation. Therefore, the poly-l-lysine bead type was also assessed in these studies. In total five different bead types are available for use in radioligand binding studies: PVT WGA, PVT-PEI Type A, PVT-PEI Type B, Ysi WGA and Ysi poly-l-lysine. PVT designates that the bead base is composed of polyvinyltoluene, while Ysi indicates a base material composed of yitrium silicate. WGA designates an untreated bead with a coating of wheat germ agglutinin, while PEI indicates that the bead was treated with polyethyleneimine either before (Type A) of after (Type B) coating with WGA.

Implementation of this technology using tritiated radioligands requires receptor expression levels greater than or equal to $2 \mathrm{pmol} / \mathrm{mg}$ in order to generate adequate signal for accurate measurements $[1-3,13]$. The $\mathrm{P} 2$ fraction of rat liver obtained through differential centrifugation contains levels of $\sigma 1$ and $\sigma 2$ receptors that exceed this requirement [14] and was thus chosen as a source of membrane.

To investigate the feasibility of using SPA for competition binding studies of sigma receptor ligands, experiments were performed with the established $\sigma 1$ receptor radioligand, $\left[{ }^{3} \mathrm{H}\right](+)$ pentazocine [15] in conjunction with rat liver P2 membranes and each of the five available SPA bead types. Preliminary studies were performed to determine basic assay parameters including: 1) optimum SPA bead type, 2) incubation time, and 3) membrane to bead ratio. Following determination of working conditions the assay was applied to the competition binding analysis of three reference sigma ligands. A more limited assessment of binding at $\sigma 2$ receptors was carried out using $\left[{ }^{3} \mathrm{H}\right] \mathrm{DTG}$ with the assay conditions determined with $\left[{ }^{3} \mathrm{H}\right](+)$-pentazocine.

\subsection{Materials and Methods}

\subsubsection{Reagents and chemicals}

$\left[{ }^{3} \mathrm{H}\right](+)$-Pentazocine (specific activity $=29 \mathrm{Ci} / \mathrm{mmol}$ ) and $\left[{ }^{3} \mathrm{H}\right] \mathrm{DTG}$ (specific activity $=53.3$ $\mathrm{Ci} / \mathrm{mmol}$ ) were purchased from Perkin Elmer (Boston, MA). (+)-Pentazocine, haloperidol, 1,3di-o-tolylguanidine (DTG), sucrose, $\mathrm{NaCl}, \quad$ dimethylsulfoxide $\quad$ (DMSO) and tris(hydroxymethyl)aminomethane (Tris), were purchased from Sigma-Aldrich (St. Louis, MO). 
NE100 (4-methoxy-3-(2-phenylethoxy)- $N, N$-dipropylbenzeneethanamine hydrochloride), BD1063 (1-[2-(3,4-dichlorophenyl)ethyl]-4-methylpiperazine dihydrochloride), and fluvoxamine maleate were from Tocris Bioscience (Ellisville, MO). SN79 (6-acetyl-3-(4-(4-(4fluorophenyl)piperazin-1-yl)butyl)benzo[d]oxazol-2(3H)-one) was obtained from Dr. Christopher McCurdy from the University of Mississippi (University, MS). Coomassie Protein Assay reagent was purchased from Fisher Scientific (Pittsburgh, PA). Scintillation proximity assay (SPA) beads were from GE LifeSciences (Piscataway, NJ).

\subsubsection{Radioligand solutions}

Solutions of $\left[{ }^{3} \mathrm{H}\right](+)$-pentazocine and $\left[{ }^{3} \mathrm{H}\right] \mathrm{DTG}$ were prepared in $50 \mathrm{mM}$ Tris, pH 8 . Concentrations of radioligand solutions were calculated based on CPM measurements and specific activities as reported by the manufacturer.

\subsubsection{Rat liver P2 membrane preparation}

Rat liver P2 homogenates were prepared as described previously and outlined below from frozen tissues obtained from Pel-Freeze (Matsumoto et al., 1995). Tissues were homogenized batchwise with a Potter-Elvehjem homogenizer (5-10 strokes with motor driven Teflon pestle) in icecold $10 \mathrm{mM}$ Tris-sucrose buffer (0.32 M sucrose in $10 \mathrm{mM}$ Tris, $\mathrm{pH} 7.4)$ using $10 \mathrm{ml}$ buffer per $\mathrm{g}$ of tissue with $\sim 3 \mathrm{~g}$ of tissue per batch. Homogenates from multiple batches were combined and centrifuged for $10 \mathrm{~min}$ at $1,000 \mathrm{x} \mathrm{g}$, at $4{ }^{\circ} \mathrm{C}$. Supernatants were decanted, combined and centrifuged for $15 \mathrm{~min}$ at $31,000 \mathrm{x} \mathrm{g}$, at $4{ }^{\circ} \mathrm{C}$. To reduce levels of bound endogenous ligand(s) the resulting $\mathrm{P}_{2}$ membrane was washed as follows: 1) pellets were re-suspended in $10 \mathrm{mM}$ Tris, pH 7.4 using $3 \mathrm{ml}$ buffer per $\mathrm{g}$ of wet tissue, 2) the resulting suspension was incubated for 30 min at $25{ }^{\circ} \mathrm{C}$, 3) following incubation, the suspension was centrifuged for $15 \mathrm{~min}$ at 31,000 $\mathrm{g}$, at $4{ }^{\circ} \mathrm{C}$. The resulting pellets were re-suspended in $10 \mathrm{mM}$ Tris, $\mathrm{pH} 7.4$ buffer at a final concentration of $1 \mathrm{~g}$ starting tissue weight/1.5 ml. Tissue preparations were aliquoted in $1 \mathrm{ml}$ portions and stored at $-80{ }^{\circ} \mathrm{C}$. The Bradford assay was used to quantitate protein concentration (Bradford, 1976). 


\subsubsection{General SPA assay considerations}

Assays utilized $50 \mathrm{mM}$ Tris, $\mathrm{pH} 8$ buffer which is the buffer most often cited in the literature for the analysis of sigma receptor binding [16]. Assay volumes were $0.2-0.3 \mathrm{ml}$, depending on the experiment. PVT WGA beads gave the best results and were used for most experiments except where noted. Non-specific binding was determined with $10 \mu \mathrm{M}$ haloperidol. Unless otherwise noted membranes and radioligand (and test ligand or haloperidol) were incubated for two hours at room temperature (RT) prior to the addition of SPA beads; samples were subsequently incubated at RT for various time periods prior to taking scintillation readings. Incubations were performed without agitation. Typically, single point determinations were made for samples, except for total and non-specific binding controls which were prepared in duplicate, or where additional replicate samples were prepared as indicated below. All samples were prepared in 0.5 $\mathrm{ml}$ polypropylene tubes and read with the tubes placed in $6 \mathrm{ml}$ scintillation vials on a Beckman LS6500 scintillation counter (Brea, CA).

\subsubsection{Determination of optimum bead type}

Initial experiments were conducted to determine the bead type with the best performance. For each of the five bead types available for radioligand binding, samples were prepared as follows: $50 \mu 1$ of $60 \mathrm{nM}\left[{ }^{3} \mathrm{H}\right](+)$-pentazocine was added to $30 \mu \mathrm{g}$ of rat liver P2 membrane in $150 \mu \mathrm{l}$ buffer. Samples were vortexed and incubated for $2 \mathrm{~h}$ at RT. Following incubation, a $100 \mu \mathrm{l}$ aliquot of bead solution containing $2 \mathrm{mg}$ beads in buffer was added to samples which were then vortexed and incubated at RT. Samples were read on the scintillation counter at $2 \mathrm{~h}$ and $20 \mathrm{~h}$

following addition of the SPA beads. For determination of the contribution of "proximity effects" to the non-specific binding signal an additional set of samples was prepared that were identical to samples prepared for total binding measurements, except membrane was omitted. Proximity effects describe signal due to radioligand that is in close enough proximity to excite the beads but is not bound to membrane or receptor.

\subsubsection{Determination of binding capacity of PVT WGA beads for rat liver P2 membranes}

To determine the optimum amount of rat liver P2 membrane to use with $1 \mathrm{mg}$ of PVT WGA beads, samples were prepared as follows: $50 \mu 1$ of $40 \mathrm{nM}\left[{ }^{3} \mathrm{H}\right](+)$-pentazocine was added to samples containing from 0 to $20 \mu \mathrm{g}$ (in $2 \mu \mathrm{g}$ increments) rat liver P2 membrane in $50 \mu \mathrm{l}$ buffer. 
Samples were vortexed and incubated for $2 \mathrm{~h}$ at RT. Following incubation, a $100 \mu \mathrm{L}$ aliquot of bead solution containing $2 \mathrm{mg}$ beads in buffer was added to samples which were then vortexed and incubated at RT. Samples were read at $\sim 10,15$ and $20 \mathrm{~h}$ following addition of beads.

\subsubsection{Determination of $\sigma 2$ binding with $\left[{ }^{3} H\right] D T G$}

To determine if SPA could be used for the analysis of $\sigma 2$ binding, samples were prepared with the same procedures that were used for $\sigma 1$ except $\left[{ }^{3} \mathrm{H}\right] \mathrm{DTG}$ was used for receptor labeling and binding of $\left[{ }^{3} \mathrm{H}\right]$ DTG to $\sigma 1$ was blocked by the addition of $(+)$-pentazocine. Samples were prepared with $16 \mu \mathrm{g}$ rat liver P2 membrane with $10 \mathrm{nM}\left[{ }^{3} \mathrm{H}\right] \mathrm{DTG}, 1 \mu \mathrm{M}(+)$-pentazocine and 2 mg of PVT WGA beads in a final volume of $200 \mu \mathrm{l}$ of $50 \mathrm{mM}$ Tris, $\mathrm{pH}$ 8. Radioligand and membrane were pre-incubated for $2 \mathrm{~h}$ in $100 \mu 1$ of $50 \mathrm{mM}$ Tris, $\mathrm{pH} 8$ prior to addition of $2 \mathrm{mg}$ SPA beads in $100 \mu 1$ of $50 \mathrm{mM}$ Tris, $\mathrm{pH} 8$. Samples were read at 1,7 and $20 \mathrm{~h}$ following addition of SPA beads.

\subsubsection{Competition binding assays}

To test the suitability of the SPA method for use in determining sigma receptor binding affinities, DTG, haloperidol, (+)-pentazocine and SN79 were used as reference compounds and were assayed using optimized conditions determined from preliminary studies. Stock solutions of test ligands were prepared in DMSO or deionized water at 5 or $25 \mathrm{mM}$. Dilutions of reference ligands for competition studies were made with assay buffer (50 mM Tris, $\mathrm{pH}$ 8). Samples were prepared as described previously containing $1 \mathrm{mg}$ of PVT-WGA beads, $8 \mu \mathrm{g}$ rat liver P2, and 10 $\mathrm{nM}\left[{ }^{3} \mathrm{H}\right](+)$-pentazocine for $\sigma 1$ assays, or $10 \mathrm{nM}\left[{ }^{3} \mathrm{H}\right] \mathrm{DTG}$ for $\sigma 2$ assays, in a final volume of $200 \mu$ l. Samples were pre-incubated for $2 \mathrm{~h}$ in $100 \mu \mathrm{l}$ of $50 \mathrm{mM}$ Tris, $\mathrm{pH} 8$ prior to addition of 1 mg SPA beads in $100 \mu 1$ of $50 \mathrm{mM}$ Tris, $\mathrm{pH}$ 8. Samples were read $20 \mathrm{~h}$ following addition of SPA beads. Test compounds were assayed at 11 concentrations varying from $0.001-10 \mu \mathrm{M}$.

\subsubsection{Data analysis}

The competition binding data were analyzed with GraphPad Prism software (San Diego, CA) using a one-site nonlinear regression model to determine the concentration of ligand that inhibits $50 \%$ of the specific binding of the radioligand $\left(\mathrm{IC}_{50}\right.$ value). $\mathrm{K}_{\mathrm{i}}$ values were calculated from the $\mathrm{IC}_{50}$ using the Cheng-Prusoff equation [17]. 


\subsection{Results}

\subsubsection{Determination of optimum bead type}

As shown in Figure 1, of the five bead types available, PVT PEI Type A and PVT WGA beads gave the highest total binding with the lowest non-specific binding (NSB) with $\left[{ }^{3} \mathrm{H}\right](+)$ pentazocine. Samples were read at 2 and $20 \mathrm{~h}$; specific binding did not change for PVT-PEI Type A or Ysi WGA over this time period while specific binding for PVT-PEI Type B, PVT WGA and Ysi poly-l-lysine increased 20-30\%. At $20 \mathrm{~h}$ post bead addition, non-specific binding (NSB), as defined by the addition of $10 \mu \mathrm{M}$ haloperidol, was $40 \%, 55 \%, 46 \%, 42 \%$, and $44 \%$ respectively for PVT-PEI type A, PVT-PEI type B, PVT WGA, Ysi WGA and Ysi poly-1-lysine beads. Signal due to proximity effects, i.e., the amount of signal observed in the absence of membrane versus in its presence, with $10 \mu \mathrm{M}$ haloperidol added to both samples, ranged from $35 \%$ to $50 \%$ and was $44 \%$ for the PVT WGA beads.

\subsubsection{Determination of optimum incubation time}

Over the course of these studies samples were read at various timepoints following the addition of SPA beads to samples. For $\sigma 1$ binding determinations with $\left[{ }^{3} \mathrm{H}\right](+)$-pentazocine the highest level of specific binding occurred around $20 \mathrm{~h}$ with no change in signal with incubation up to 25 h. Interestingly, determinations of $\sigma 2$ binding with $\left[{ }^{3} \mathrm{H}\right] \mathrm{DTG}$ had the highest specific binding signal at $1 \mathrm{~h}$, compared to identical samples incubated for 7 or $20 \mathrm{~h}$. Additional time points were not examined with $\left[{ }^{3} \mathrm{H}\right] \mathrm{DTG}$.

\subsubsection{Determination of binding capacity of PVT WGA beads for rat liver P2}

The binding capacity of the PVT WGA bead was determined by adding varying amounts of membrane, labeled with $\left[{ }^{3} \mathrm{H}\right](+)$-pentazocine, to $1 \mathrm{mg}$ of bead per sample. Figure 2 shows the binding function is curvilinear from 0 to $20 \mu \mathrm{g}$ membrane with a linear increase in non-specific binding over this range resulting in a linear region of specific binding from $0-10 \mu \mathrm{g}$ of added tissue per $\mathrm{mg}$ of bead in $200 \mu \mathrm{l}$ of $50 \mathrm{mM}$ Tris, $\mathrm{pH} 8$. In addition to varying receptor concentration with a fixed bead amount, we also tested the effect of bead amount with a fixed quantity of membrane. With $30 \mu \mathrm{g}$ of membrane combined with 0.25 to $3 \mathrm{mg}$ of SPA beads the specific binding increased linearly but non-specific binding remained constant at approximately 
$35 \%$. Therefore, it does not appear that excess membrane adversely affects background but as demonstrated previously it does lead to non-linear binding of radioligand. It also does not appear that there is any advantage to using more than $1 \mathrm{mg} /$ well of SPA beads with our current procedure.

\subsubsection{Determination of $\sigma 2$ binding with $\left[{ }^{3} H\right] D T G$}

To determine if SPA could be used for the analysis of $\sigma 2$ binding, samples were prepared with the same procedures that were used for $\sigma 1$ binding except $\left[{ }^{3} \mathrm{H}\right] \mathrm{DTG}$ was used for labeling sigma receptors. Because $\left[{ }^{3} \mathrm{H}\right] \mathrm{DTG}$ does not discriminate between $\sigma 1$ and $\sigma 2$ receptors, exhibiting nearly equal affinity for both subtypes [15], the standard method of blocking $\sigma 1$ with (+)pentazocine was required [15]. Samples prepared with $16 \mu \mathrm{g}$ rat liver P2 membrane with $20 \mathrm{nM}$ [ $\left.{ }^{3} \mathrm{H}\right]$ DTG and $2 \mathrm{mg}$ of PVT WGA beads resulted in non-specific binding of $\sim 42 \%$. This is similar to the level observed with $\left[{ }^{3} \mathrm{H}\right](+)$-pentazocine. Addition of (+)-pentazocine to block $\sigma 1$ results in a signal approximately $50 \%$ lower than in its absence. This produced an effective $40 \%$ specific binding at $\sigma 2$. These data are shown graphically in Figure 3. Signal due to proximity effects for $\left[{ }^{3} \mathrm{H}\right] \mathrm{DTG}$ was approximately $50 \%$ compared to approximately $45 \%$ observed with $\left[{ }^{3} \mathrm{H}\right](+)$-pentazocine analyzed under similar conditions.

\subsubsection{Competition binding of established sigma ligands}

Competition binding curves for haloperidol, (+)-pentazocine and DTG binding to $\sigma 1$ receptors were generated with samples containing varying concentrations of the test ligands, $10 \mathrm{nM}$ $\left[{ }^{3} \mathrm{H}\right](+)$-pentazocine, $8 \mu \mathrm{g}$ membrane and $1 \mathrm{mg}$ PVT WGA beads in $200 \mu \mathrm{l}$ total volume. The binding curves are shown in Figure 4. For haloperidol and (+)-pentazocine, calculated equilibrium dissociation constants $\left(\mathrm{K}_{\mathrm{i}}\right)$ were in excellent agreement with values determined by 96-well filtration binding using rat liver $\mathrm{P} 2$. For haloperidol, $\mathrm{K}_{\mathrm{i}}(\mathrm{SPA})=3.4 \mathrm{nM}$ versus $\mathrm{K}_{\mathrm{i}}(96-$ well $)=3.3 \pm 0.6$, and for $(+)$-pentazocine, $K_{\mathrm{i}}(\mathrm{SPA})=15.8 \mathrm{nM}$ versus $\mathrm{K}_{\mathrm{i}}(96$-well $)=13.3 \pm 1.8$. The "96-well" values in the preceding comparison are from the 96-well filtration study that is the subject of Chapter 3 of this document. Agreement between SPA and 96-well filtration was fair with DTG with $\mathrm{K}_{\mathrm{i}}(\mathrm{SPA})=228 \mathrm{nM}$ versus $\mathrm{K}_{\mathrm{i}}(96$-well $)=55.9 \pm 3.9$. A competition binding curve for SN79 binding to $\sigma 2$ was generated with samples containing varying concentrations of SN79, $10 \mathrm{nM}\left[{ }^{3} \mathrm{H}\right] \mathrm{DTG}, 1 \mu \mathrm{M}(+)$-pentazocine, $8 \mu \mathrm{g}$ membrane and $1 \mathrm{mg}$ PVT WGA beads in 
$200 \mu 1$ total volume. The resulting binding curve is shown in Figure 5. The calculated equilibrium dissociation constant was in fair agreement with the value reported in the literature (determined in our lab) using a conventional filtration assay with rat brain P2. The value determined in this study was $\mathrm{K}_{\mathrm{i}}(\mathrm{SPA} /$ rat liver $)=23.8 \mathrm{nM}$ versus $\mathrm{K}_{\mathrm{i}}($ conventional $/$ rat brain $)=$ $7.00 \pm 0.09$ reported by Kaushal et al [18].

\subsection{Discussion}

The results of this study suggest that SPA is a feasible alternative technology for determining competition binding affinities of sigma receptor ligands; the $\mathrm{K}_{\mathrm{i}}$ values for reference compounds determined with SPA in this study were in good agreement with binding affinities determined by conventional filtration methods. However, additional work will be required to improve the performance of this method because background levels currently exceed levels recommended by the NIH for SPA assays [19]. Efforts to reduce background were not made in these preliminary studies; however, improvements may be achieved through: 1) the use of more highly purified receptor preparations, 2) the inclusion of buffer additives, and 3) in the case of the analysis of $\sigma 2$ receptor binding, the use of a subtype specific radioligand.

The conditions used to determine $\mathrm{K}_{\mathrm{i}}$ values for binding to $\sigma 1$ receptors resulted in a non-specific signal of approximately $40 \%$ of the total signal. Approximately $70 \%$ of this non-specific signal can be attributed to membrane binding, with the remainder due to proximity effects. This conclusion is based on signal observed in the presence of added membrane versus signal observed in the absence of added membrane. Because most of the non-specific signal is due to membrane binding this may reflect the quality of the radioligand. $\left[{ }^{3} \mathrm{H}\right](+)$-Pentazocine and other radioligands have in our hands been demonstrated to degrade and a primary indicator is increased non-specific binding. The benchmark would be the level of non-specific binding (15$20 \%$ ) that was observed for rat liver P2 membrane processed by 96-well filtration, as determined in studies detailed in Chapter 3 of this document.

The high background level we observed may be improved by further purification of the receptor preparation or the use of different radioligands. The effect of membrane source and radioligand 
has been tested in defined systems and differences in signal due to non-specific sources can be dramatic. Carrick et al. [8] compared $\left[{ }^{3} \mathrm{H}\right] \mathrm{LSD}$ binding to membranes and whole cells from $\mathrm{CHO}$ and Hela cells expressing human $5-\mathrm{HT}_{6}$ receptors. They found that membranes from $\mathrm{CHO}$ gave less than $10 \%$ specific binding but whole cells yielded $>80 \%$ specific binding [8]. Similarly, Hela membranes gave $<30 \%$ specific binding while whole cells treated with sodium boride gave $70-80 \%$ specific binding [8]. They also tested $\left[{ }^{3} \mathrm{H}\right] \mathrm{LSD},\left[{ }^{125} \mathrm{I}\right] \mathrm{LSD}$ and $\left[{ }^{3} \mathrm{H}\right] 5-\mathrm{HT}$ with the CHO membranes and found $<30 \%,<10 \%$ and $<20 \%$ specific binding respectively [8]. These experiments show very clearly that the receptor preparation and radioligand can have a significant impact on background levels.

The results of our studies show that SPA WGA beads gave the optimum signal to noise with a membrane to bead ratio of $8 \mu \mathrm{g}$ rat liver P2 per mg of SPA bead. The amount of membrane that will bind to SPA WGA beads is limited to $10-30 \mu \mathrm{g}$ membrane/mg of bead [1-3]. Therefore, the amount of membrane bound per mg of bead we observed was consistent with expectations. Significant improvements in signal to noise or reductions in the amount of SPA bead used per well may be realized for $\sigma 1$ binding assays if a cell line over-expressing $\sigma 1$ receptors are used as a source of membranes. Filter binding assays with MCF-7 cells stably expressing human $\sigma 1$ receptors at $\sim 100 \mathrm{pmol} / \mathrm{mg}$ (determined with $\left[{ }^{3} \mathrm{H}\right](+)$-pentazocine) yielded similar binding affinities for reference compounds compared to historical values determined in tissues [20]. Therefore, with this or a similar cell line over-expressing $\sigma 1$ receptors, there is the potential for binding 20 to 30-fold more receptors for the same mass of membrane, relative to rat liver P2 membranes that contain $\sigma 1$ receptors with a $B_{\max }$ of $\sim 3 \mathrm{pmol} / \mathrm{mg}$. The increased number of bead bound receptors would be expected to generate higher specific signal levels for a given amount of SPA bead. Cell lines over-expressing $\sigma 2$ receptors cannot be produced at this time because the $\sigma 2$ receptor has not been cloned; therefore, this strategy cannot be utilized for the analysis of the б2 subtype.

Incubation times of approximately 20 hours were required for a stable SPA signal with $\sigma 1$ receptors. Relatively long incubation times are utilized in most published SPA studies [7, 9]. Rodgers et al. [7] reported binding of $\left[{ }^{3} \mathrm{H}\right] \mathrm{DPN}$ (diprenorphine) to human $\mu$ opioid receptors expressed in CHO cells with WGA SPA and a total incubation time of 8 h. Hui et al. [9] used 
WGA beads with HEK293 cells expressing $\alpha 4 \beta 2$ nAChR, labeled with $\left[{ }^{3} \mathrm{H}\right]$ cytosine and incubated for $12 \mathrm{~h}$. Our experiments suggest $\sigma 1$ receptor stability is not a problem because signals for $\sigma 1$ binding increased until $20 \mathrm{~h}$ and were stable to at least $25 \mathrm{~h}$. It is not clear why the signal for $\sigma 2$ receptors was highest at $1 \mathrm{~h}$ versus 7 or $10 \mathrm{~h}$. If stability issues emerge as the assay is further optimized, as evidenced by irreproducible results, or derived $\mathrm{K}_{\mathrm{i}}$ values for reference compounds that are inconsistent with known values, addition of protease inhibitor(s) to assay samples may be necessary. Addition of protease inhibitors to receptor preparations for radioligand binding is a common practice [21] and would not be expected to adversely affect the analysis.

$\left[{ }^{3}\right.$ H]DTG was successfully utilized to label $\sigma 2$ receptors in our study. DTG does not discriminate between $\sigma 1$ and $\sigma 2$ receptors, exhibiting similar affinity for both subtypes, with $\mathrm{K}_{\mathrm{i}} \sigma 1=\sim 74 \mathrm{nM}$ and $\mathrm{K}_{\mathrm{i}} \sigma 2=\sim 61 \mathrm{nM}$ [16]. Consequently, it was unclear whether $\left[{ }^{3} \mathrm{H}\right] \mathrm{DTG}$ would yield adequate specific signal with SPA to support use in further studies. The results suggest that adequate signal is obtained with $\left[{ }^{3} \mathrm{H}\right] \mathrm{DTG}$ but because only $40 \%$ of total binding was specific relative to $\sigma 2$ after blocking $\sigma 1$ receptors this assay is considerably less than optimal. However, the binding affinity determined for SN79 was in fair agreement with the value determined by 96-well filtration despite the high non-specific signal. A significant improvement may be realized with the development and introduction of a higher affinity and/or more selective $\sigma 2$ radioligand.

In conclusion, it appears that SPA represents a potentially useful format for assaying sigma receptor radioligand binding. A major drawback of the method as currently configured is the cost of SPA beads which are approximately $\$ 1$ per $\mathrm{mg}$ or $\$ 1 /$ well. While in the final analysis, this may be cost competitive with conventional filtration assays if one factors in labor and other costs; a reduction in the amount of SPA beads required per sample well by a factor of 2 to 4 -fold would make the method significantly more attractive. This may be possible if radioligands with higher specific activity become available (e.g., $\left[{ }^{125} \mathrm{I}\right]$ ) or if cell lines over-expressing receptors are used as a source of membranes. However, this method in its current form may still prove useful in situations where a researcher has access to a scintillation counter, but does not have a cell harvester. It should be noted that the studies presented here utilized a standard scintillation counter for reading samples, not a 96-well plate specific counter. 
A

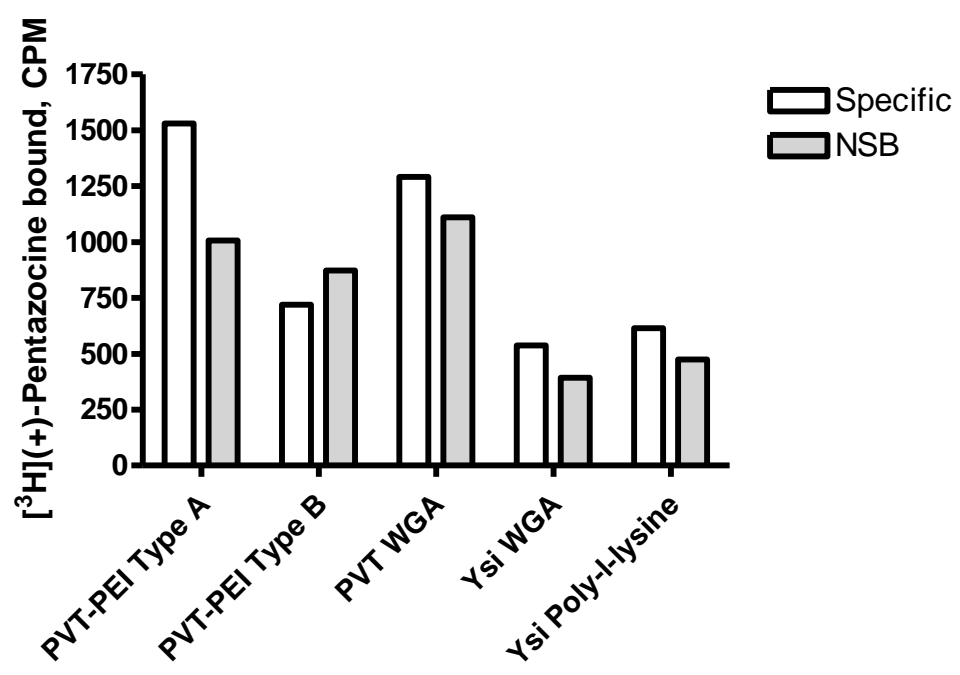

B

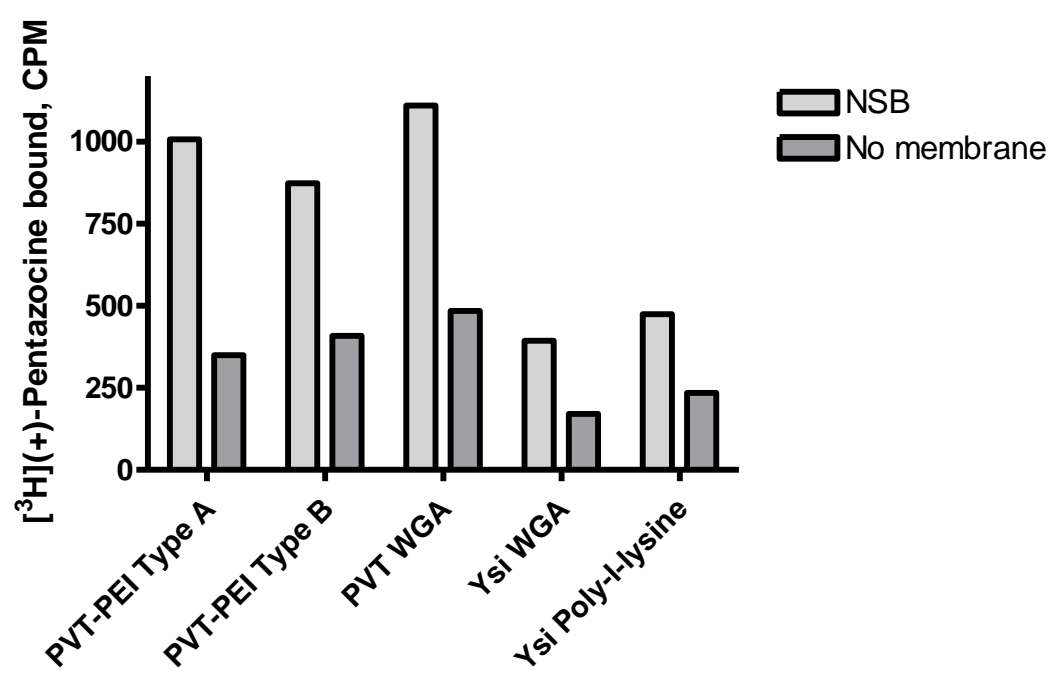

Figure 1. Binding of $\left[{ }^{3} \mathrm{H}\right](+)$-pentazocine to rat liver P2 membranes analyzed with five SPA bead types. Samples contained $10 \mathrm{nM}\left[{ }^{3} \mathrm{H}\right](+)$-pentazocine, $30 \mu \mathrm{g}$ rat liver P2, and $2 \mathrm{mg}$ SPA beads, in a total volume of $300 \mu \mathrm{l}$ of $50 \mathrm{mM}$ Tris, pH 8 buffer. (A) For the determination of nonspecific (NSB) binding identical samples were prepared containing $10 \mu \mathrm{M}$ haloperidol. (B) For the determination of background due to the interaction of beads with radioligand (No membrane), samples were prepared containing only radioligand, $10 \mu \mathrm{M}$ haloperidol, and beads. 
A

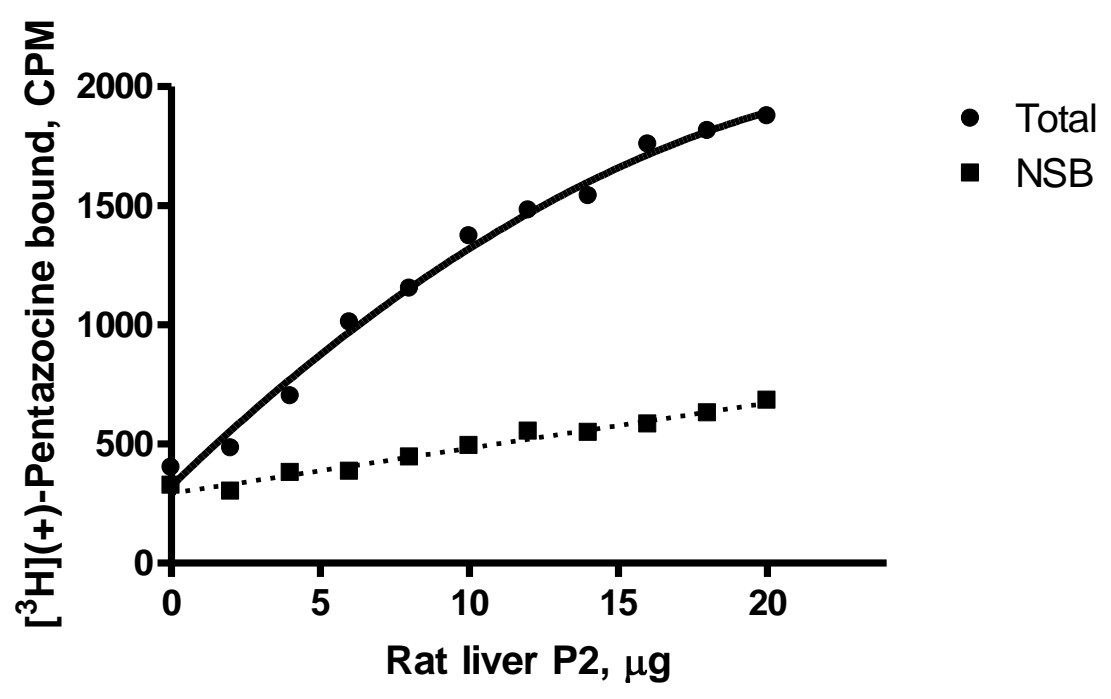

B

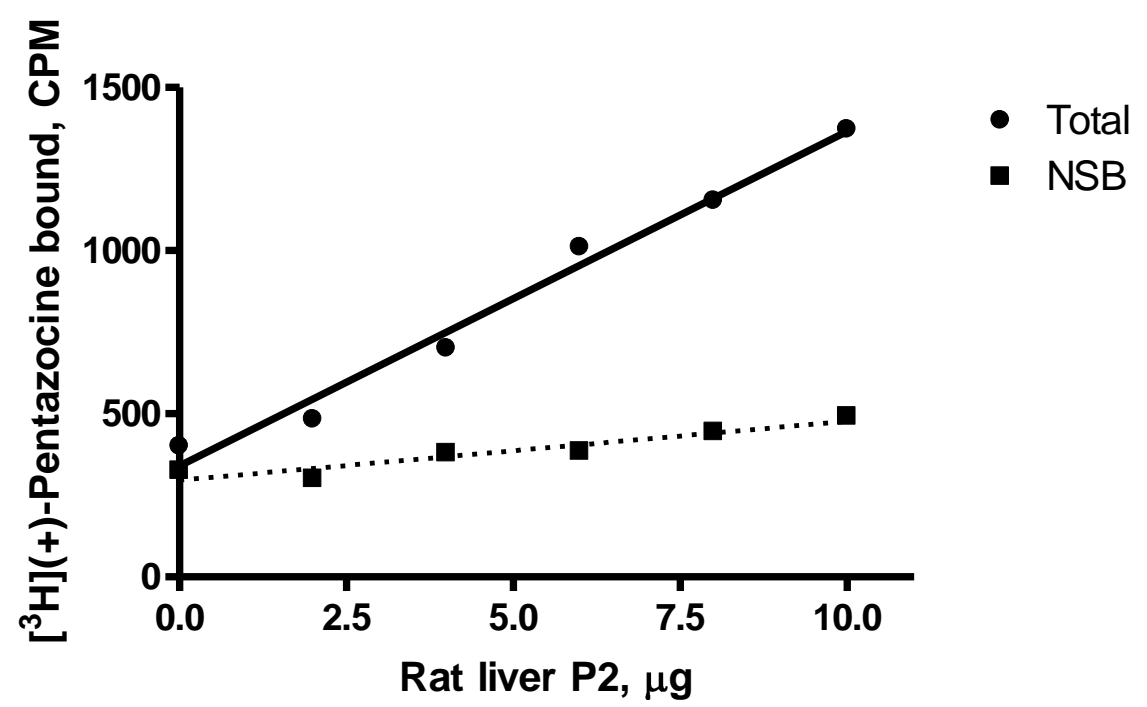

Figure 2. Binding linearity of $\left[{ }^{3} \mathrm{H}\right](+)$-pentazocine to rat liver P2 with PVT WGA SPA beads. Samples contained $10 \mathrm{nM}\left[{ }^{3} \mathrm{H}\right](+)$-pentazocine, varying amounts of rat liver P2, and $1 \mathrm{mg}$ WGA SPA beads, in a total volume of $200 \mu$. Data points represent single determinations. (A) Total and non-specific binding (NSB) for 0-20 $\mu \mathrm{g}$ rat liver P2/mg of SPA beads. (B) Total and nonspecific binding for the linear range of binding. 


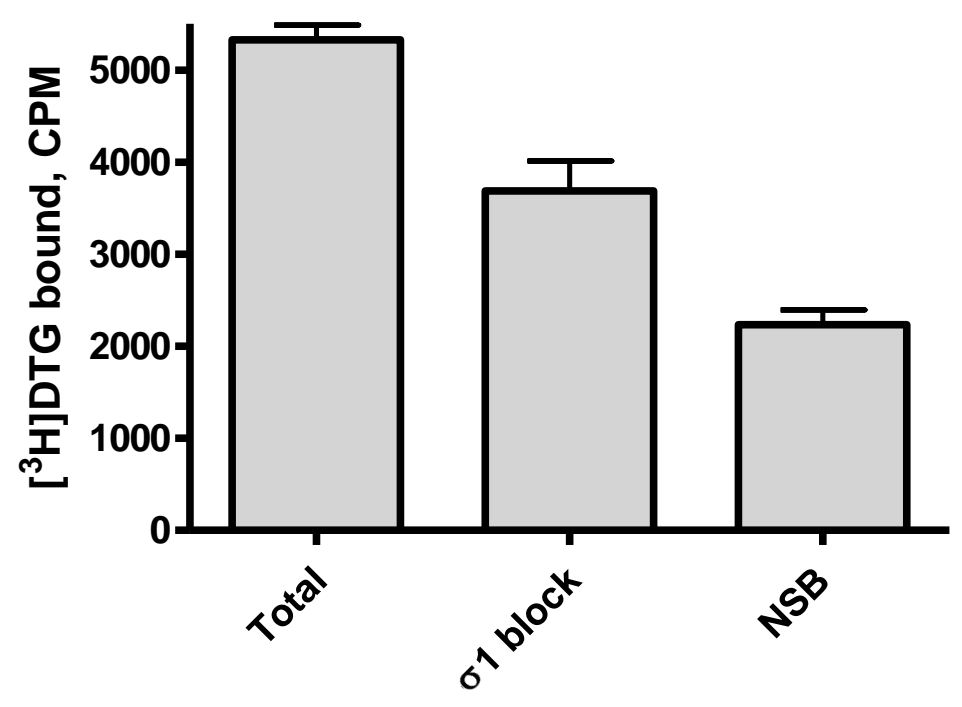

Figure 3. Binding of $\left[{ }^{3} \mathrm{H}\right] \mathrm{DTG}$ to rat liver P2 membranes with PVT WGA SPA beads. Samples contained $10 \mathrm{nM} \mathrm{[}{ }^{3} \mathrm{H}$ ]DTG, $16 \mu \mathrm{g}$ of rat liver P2, and $2 \mathrm{mg}$ WGA SPA beads, in a total volume of $200 \mu \mathrm{l}$. Data shown is for $1 \mathrm{~h}$ time point which resulted in maximum signal versus 7 and $20 \mathrm{~h}$ readings. Binding due to $\sigma 2$ and NSB ( $\sigma 1$ block) was determined by adding $1 \mu \mathrm{M}(+)-$ pentazocine. Non-specific binding (NSB) was determined by adding $10 \mu \mathrm{M}$ haloperidol. Data points represent triplicate determinations; error bars indicate SEM. 


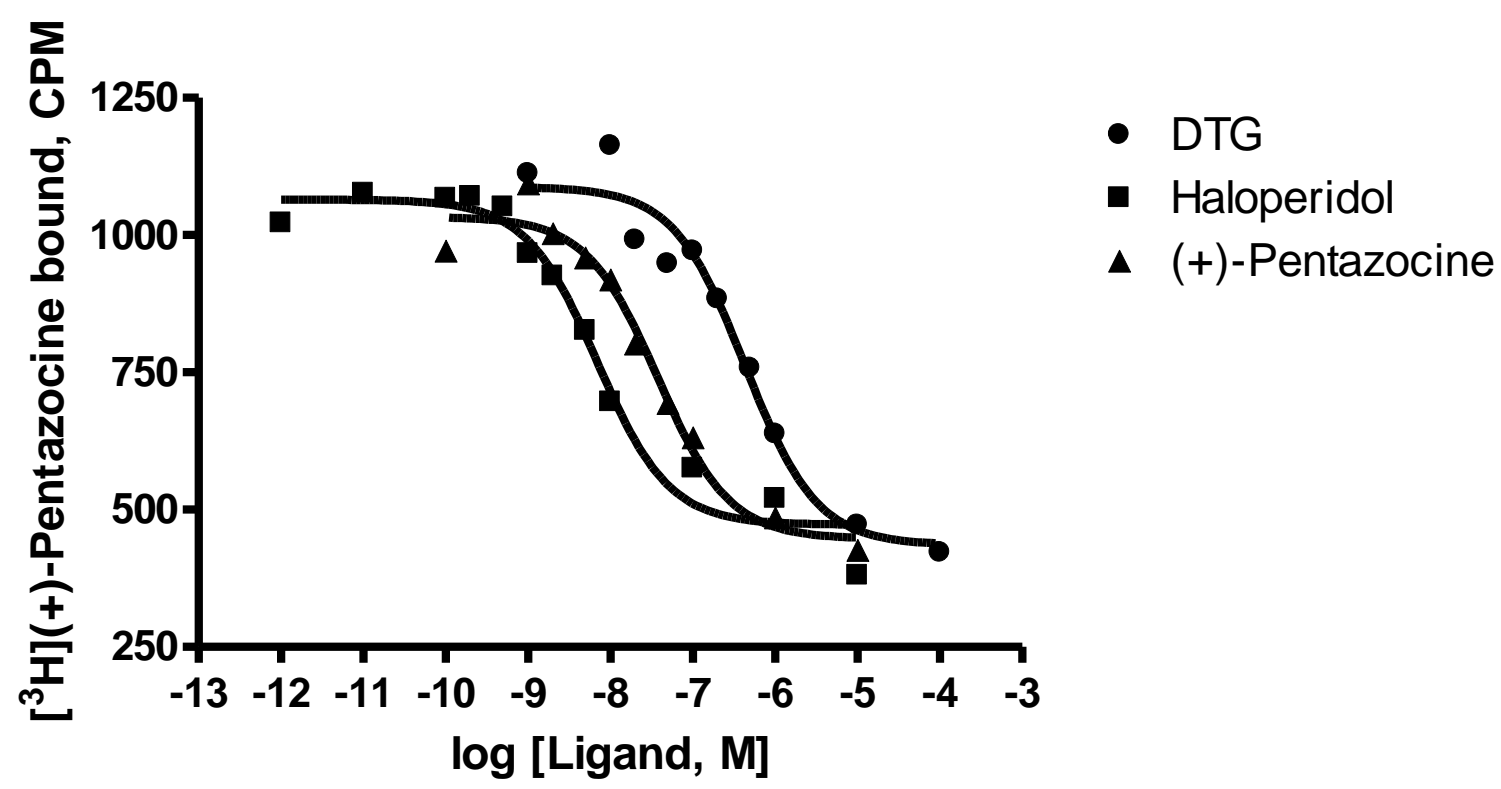

Figure 4. Competition binding curves for DTG, haloperidol, and (+)-pentazocine versus $\left[{ }^{3} \mathrm{H}\right](+)-$ pentazocine at $\sigma 1$. Samples contained $10 \mathrm{nM}\left[{ }^{3} \mathrm{H}\right](+)$-pentazocine, $8 \mu \mathrm{g}$ rat liver $\mathrm{P} 2$, and $1 \mathrm{mg}$ WGA SPA beads, in a total volume of $200 \mu$. Test ligands were added at 11 concentrations from $1 \mathrm{pM}-100 \mu \mathrm{M}$. Data points represent single determinations. 


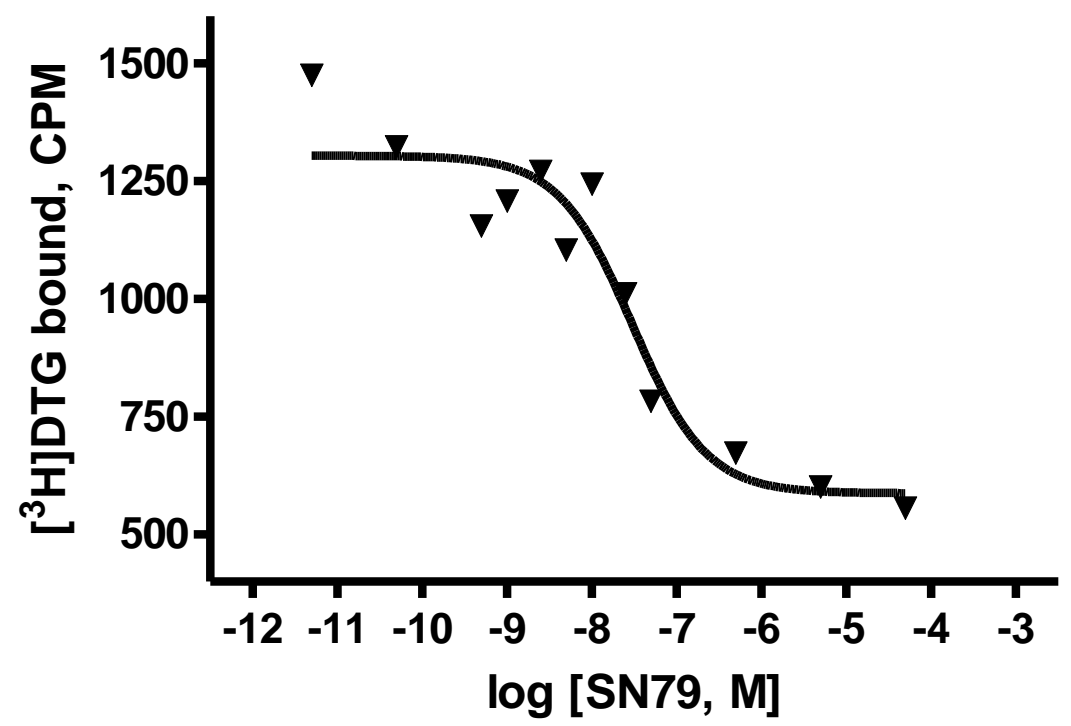

Figure 5. Competition binding curve for SN79 at $\sigma 2$ receptors. Samples contained $10 \mathrm{nM}$ $\left[{ }^{3} \mathrm{H}\right] \mathrm{DTG}, 1 \mu \mathrm{M}$ (+)-pentazocine, $8 \mu \mathrm{g}$ rat liver P2, and $1 \mathrm{mg}$ WGA SPA beads, in a total volume of $200 \mu \mathrm{l}$. Test ligands were added at 11 concentrations from $1 \mathrm{pM}-100 \mu \mathrm{M}$. Data points represent single determinations. 


\subsection{References}

1. Amersham, Optimization of SPA Receptor Binding Assays, in Proximity News. 1996.

2. Amersham Product Guide. 2005, General Electric Company.

3. Scintillation Proximity Assay Manual, Amersham Biosciences.

4. Glickman, J.F., A. Schmid, and S. Ferrand, Scintillation proximity assays in highthroughput screening. Assay Drug Dev Technol, 2008. 6(3): p. 433-55.

5. Johnson, E.N., et al., A 1,536-well [(35)S]GTPgammaS scintillation proximity binding assay for ultra-high-throughput screening of an orphan galphai-coupled GPCR. Assay Drug Dev Technol, 2008. 6(3): p. 327-37.

6. $\mathrm{Wu}, \mathrm{S}$. and B. Liu, Application of scintillation proximity assay in drug discovery. BioDrugs, 2005. 19(6): p. 383-92.

7. Rodgers, G., et al., Development of displacement binding and GTPgammaS scintillation proximity assays for the identification of antagonists of the micro-opioid receptor. Assay Drug Dev Technol, 2003. 1(5): p. 627-36.

8. Carrick, T., et al., Development of a scintillation proximity assay binding method for the human 5-hydroxytryptamine 6 receptor using intact cells. Anal Biochem, 2008. 381(1): p. 27-32.

9. Hui, X., et al., A robust homogeneous binding assay for alpha4beta2 nicotinic acetylcholine receptor. Acta Pharmacol Sin, 2005. 26(10): p. 1175-80.

10. $\quad \mathrm{Su}, \mathrm{T} . \mathrm{P}$. , et al., The sigma-1 receptor chaperone as an inter-organelle signaling modulator. Trends Pharmacol Sci, 2010. 31(12): p. 557-66.

11. Hayashi, T. and T.P. Su, Sigma-1 receptor chaperones at the ER-mitochondrion interface regulate $\mathrm{Ca}(2+)$ signaling and cell survival. Cell, 2007. 131(3): p. 596-610. 
12. Vance, J.E., Phospholipid synthesis in a membrane fraction associated with mitochondria. J Biol Chem, 1990. 265(13): p. 7248-56.

13. Davenport, A.P., ed. Receptor Binding Techniques. 2 ed. Methods in Molecular Biology 2005, Humana Press. 256.

14. Hellewell, S.B., et al., Rat liver and kidney contain high densities of sigma 1 and sigma 2 receptors: characterization by ligand binding and photoaffinity labeling. Eur $\mathrm{J}$ Pharmacol, 1994. 268(1): p. 9-18.

15. Quirion, R., et al., A proposal for the classification of sigma binding sites. Trends Pharmacol Sci, 1992. 13(3): p. 85-6.

16. Bowen, W.D., et al., [3H]-(+)-Pentazocine: a potent and highly selective benzomorphanbased probe for sigma-1 receptors. Molecular Pharmacology, 1993. 1(3): p. 117-126.

17. Cheng, Y. and W.H. Prusoff, Relationship between the inhibition constant (K1) and the concentration of inhibitor which causes 50 per cent inhibition (I50) of an enzymatic reaction. Biochem Pharmacol, 1973. 22(23): p. 3099-108.

18. Kaushal, N., et al., Synthesis and Pharmacological Evaluation of 6-Acetyl-3-(4-(4-(4fluorophenyl)piperazin-1-yl)butyl)benzo[d]oxazol-2(3H) -one (SN79), a Cocaine Antagonist, in Rodents. AAPS J, 2011.

19. NCGC. Assay Guidance/Assay Guidance Manual/Receptor Binding Assays. 2008 [cited 2011 June 1, 2011]; Available from: http://www.ncgc.nih.gov/guidance/section5.html.

20. Lee, I.T., S. Chen, and J.A. Schetz, An unambiguous assay for the cloned human sigmal receptor reveals high affinity interactions with dopamine $D 4$ receptor selective compounds and a distinct structure-affinity relationship for butyrophenones. 2008. 578(2-3): p. 123-136.

21. Boulton, A.A., ed. In Vitro Neurochemical Techniques. 1st ed. Neuromethods. 1999, Humana Press. 20-21. 


\section{CHAPTER 5}

\section{Development of an Alphascreen assay for the determination of the in vitro functional activity of $\sigma 1$ ligands}




\subsection{Abstract}

The $\sigma 1$ receptor represents an attractive drug development target for a number of therapeutic indications including cancer, depression, psychostimulant abuse, and stroke. Functionally, $\sigma 1$ receptors appear to operate primarily via protein-protein interactions and have been shown to modulate the activity of a variety of ion channels and signaling molecules. Currently there are no in vitro functional assays available that are amenable to routine use for the determination of $\sigma 1$ ligand activities. The availability of such an assay would greatly aid in the development of $\sigma 1$ targeted therapeutics by providing a rational approach to selecting compounds for in vivo evaluation and in facilitating design of new synthetic $\sigma 1$ ligands. A recently identified proteinprotein interaction between $\sigma 1$ and binding immunoglobulin protein (BiP) appears to provide a relevant target for selectively evaluating the functional activity of $\sigma 1$ receptor ligands. Alphascreen was chosen as a platform for development of an assay that exploits the disruption of this interaction as a read-out of $\sigma 1$ activation. The current studies utilized Alphascreen for experiments with purified affinity-tagged $\sigma 1$ and $\mathrm{BiP}$ proteins in a cell free system, and an ELISA format was utilized to examine the behavior of $\sigma 1 / \mathrm{BiP}$ in lysates prepared from cultured cells and animal tissues. The Alphascreen experiments were unsuccessful due in part to the apparent interaction of $\sigma 1$-FLAG with the nickel-chelate donor bead that was intended to interact specifically with 6XHis-BiP. However, the proposed Alphascreen scheme performed as designed with a control peptide that mimicked the intended interactions of the affinity tags with donor and acceptor beads, and yielded important information for the design of future schemes. Attempts to capture $\sigma 1$-FLAG by conventional immunoprecipitation with a FLAG affinity resin were unsuccessful, despite successful pulldown of a control bacterial alkaline phosphatase FLAG fusion protein in this same system. Attempts to capture $\sigma 1$ from rat liver or $\mathrm{CHO}$ cell lysates on polystyrene ELISA plates passively coated with $\sigma 1$ or BiP antibodies were also unsuccessful. Despite predominantly negative results this preliminary assessment provided valuable data for future studies. This data coupled with a recent report of a simple procedure for isolating endogenously expressed $\sigma 1 / \mathrm{BiP}$ complexes suggest a functional assay for $\sigma 1$ ligands based on Alphascreen remains a viable research goal. Additional work is proposed that addresses the shortcomings observed in the current work. 


\subsection{Introduction}

The $\sigma 1$ receptor functions as a chaperone protein and modulates the activities of ion channels [110]. This modulatory role can be affected by well-established ligands that operate in an agonist/antagonist relationship with $\sigma 1$ receptors $[2-4,7,11,12]$. Importantly, $\sigma 1$ receptors are also known to translocate from the mitochondrial associated membrane (MAM) to the endoplasmic reticulum (ER) and plasmalemma in response to agonist ligand stimulation, assuming different roles depending on their cellular location $[2,13,14]$. Currently there are no in vitro assays available that are amenable to routine use for screening $\sigma 1$ ligand activities. The availability of such a method would facilitate more efficient development of $\sigma 1$ receptor ligands as potential therapeutics. Therefore, we sought to develop an in vitro assay based on the recently identified ligand sensitive interaction between $\sigma 1$ and binding immunoglobulin protein (BiP) [3]. This interaction is disrupted in the presence of $\mathrm{K}^{+}, \mathrm{Mg}^{2+}$, ATP and established sigma agonist compounds, and is promoted in the presence of $\mathrm{Mn}^{2+}, \mathrm{Ca}^{2+}$ and sigma antagonists, and thus appears to provide a relevant target for evaluating the functional activity of $\sigma 1$ receptor ligands $[3,15]$.

In 2007 Hayashi and $\mathrm{Su}$ [3] reported that the interaction of $\sigma 1$ receptors and $\mathrm{BiP}$ regulates $\mathrm{Ca}^{2+}$ signaling between the ER and mitochondria via $\mathrm{IP}_{3}$ receptors localized at focal points called the MAM. The $\sigma 1 /$ BiP complex was observed by Western analysis following immunoprecipitation of $\sigma 1$ or $\mathrm{BiP}$ from CHAPS (3-[(3-cholamidopropyl)dimethylammonio]-1-propanesulfonate) lysates of wild-type $\mathrm{CHO}$ (Chinese hamster ovary) cells, and $\mathrm{CHO}$ cells expressing recombinant $\sigma 1$-EYFP (enhanced yellow fluorescent protein) [3]. The dose-dependant sigma receptor agonist sensitive behavior of this $\sigma 1 / \mathrm{BiP}$ complex was demonstrated by co-immunoprecipitation studies with crude lysates of cells expressing o1-EYFP exposed in situ to sigma ligands [3]. Application of sigma receptor antagonists in this system prevented the action of agonists but had minimal effect when they were administered alone.

Additional studies with a GST (glutathione S-transferase) fusion construct of the ER luminal domain of the $\sigma 1$ receptor (GST-Sig-1R116-223) coupled to sepharose beads provided evidence that the interaction of $\sigma 1$ with $\mathrm{BiP}$ is through this domain and can occur in a lipid- and cell-free 
environment [3]. Using this system, recombinant BiP was precipitated from a simple buffer comprised of $50 \mathrm{mM}$ Tris, $\mathrm{pH} 7.4,0.5 \%$ NP-40, and endogenous BiP was precipitated from crude lysates of rat tissue homogenates [3]. Further, the interaction of the construct and recombinant $\mathrm{BiP}$ was sensitive to $\mathrm{Mn}^{2+}$ and $\mathrm{Ca}^{2+}$, similar to the behavior of the $\sigma 1-\mathrm{EYFP} / \mathrm{BiP}$ complex observed in CHAPS cell lysates from CHO cells expressing $\sigma 1-E Y F P$ [3]. Because this construct does not contain the putative ligand binding site(s) this system would not be expected to respond to application of sigma ligands but the effect of application of ligands as a control was not reported. Therefore, it is not certain that the interaction observed in this model is identical to the sigma ligand sensitive interaction detected in $\mathrm{CHO}$ cell lysates. However, the combined evidence strongly suggests that the observed interaction is the same in CHO cells and this model. Together, these studies provide support for our proposed approach to utilize lysates from liver or cultured cells, or recombinant proteins as a source of the $\sigma 1 / \mathrm{BiP}$ complex for development of a functional assay based on exogenous application of sigma ligands.

A number of in vitro and ex vivo systems have been reported which respond to $\sigma 1$ agonists in a predictable manner [16-19]. However, none of these methods is amenable to high throughput use. Moreover, these assays rely on measurement of effects downstream of $\sigma 1$ activation and thus do not provide the simplicity or relevancy that an assay based on the interaction $\sigma 1$ and $\mathrm{BiP}$ would. The phenytoin-induced modulation of agonist binding at $\sigma 1$ in guinea-pig brain membrane homogenates is an established effect that appears to distinguish $\sigma 1$ agonists from antagonists [20-23]. However, this effect cannot be exploited as a quantitative activity assay and the mechanism of the effect is unknown. Cell-based assays that exploit changes in $\mathrm{Ca}^{2+}$ levels lack the quantitative precision and dynamic range required to adequately capture accurate doseresponse curves, and also represent downstream effects of receptor activation [16]. Quantitative cell based assays relying on $\sigma 1$ agonist induced neurite outgrowth [19, 24] also depend on downstream effects and have so far only been demonstrated with a limited number of compounds. The ligand sensitive $\sigma 1 / \mathrm{BiP}$ interaction represents a mechanism that is: 1) of relatively low complexity, 2) appears to be the first step in a cascade of $\sigma 1$ activities as $\sigma 1$ translocates in response to ligand stimulation or cellular stress [3,11], and 3) is amenable to examination with well-established immunological based techniques. Therefore, we believe an 
assay based on the agonist sensitive interaction of $\sigma 1$ and $\mathrm{BiP}$ provides the best approach currently available for screening the functional activity of $\sigma 1$ ligands.

Assay formats that could potentially facilitate measurement of the intact versus the disrupted $\sigma 1 / \mathrm{BiP}$ complex include conventional immunoprecipitation, ELISA, Alphascreen, and Surface Plasmon Resonance (SPR). Alphascreen, the proposed assay format for our studies, is immunologically based, relying on recognition of native epitopes, or recognition of tagged overexpressed proteins [25-28]. Alphascreen beads are available with a variety of common immunological substrates attached (streptavidin, protein $\mathrm{A} / \mathrm{G}$, anti-affinity tag antibodies, etc.), providing considerable flexibility in designing assays [27, 28]. Method development is fast, and assays, once developed, are easy to perform with only addition and mixing of components required prior to reading on a plate reader. Conventional immunoprecipitation and ELISA formats are useful for determining the appropriate bead scheme and determining assay conditions but ultimately a properly-designed Alphascreen assay can facilitate medium and high throughput analysis with considerably less effort than either of these methods. Moreover, Alphascreen is more sensitive and has a higher dynamic range than ELISA, allowing for more precise determinations of $\mathrm{EC}_{50} \mathrm{~s}$ [25]. SPR may provide an alternative and perhaps superior means of quantitating the $\sigma 1 / \mathrm{BiP}$ interaction; however, at this stage of method development it does not provide the flexibility to investigate experimental variables as efficiently as is possible with our proposed methods. Indeed, the requirement of determining the best attachment method, corresponding SPR chip and instrumental parameters only serves to compound the complexity of the primary goals of observing an in vitro interaction of $\sigma 1 / \mathrm{BiP}$, and the effect of sigma ligands on this interaction. Therefore, until operational parameters are better defined, SPR does not offer any obvious advantages over our proposed methods.

To exploit the interaction of $\sigma 1$ and $\mathrm{BiP}$ for the development of an immunologically-based in vitro assay numerous factors must be considered which include: sample source, antibodies, assay format, sample preparation, and the assay matrix. Potential sources of $\sigma 1$ and BiP proteins include animal tissue or cell culture derived membranes or lysates, where cell culture derived samples can be from wild-type cells or cells expressing recombinant proteins with affinity tags. Tagged proteins can also be purified from the over-expressed systems and used in a cell free 
system. Antibodies are available for several native epitopes on both $\sigma 1$ and BiP. While antibodies for affinity tags are highly specific and provide strong interactions, these tags may interfere with the $\sigma 1 / \mathrm{BiP}$ complex. Further, sample preparation and assay matrices must be compatible with the chosen assay format and potential involvement of lipids and/or unidentified protein partners in the functional $\sigma 1 / \mathrm{BiP}$ complex must also be considered.

Despite evidence that a $\sigma 1 / \mathrm{BiP}-$ like complex can exist in cell free conditions [3], it is not known if the $\sigma 1$ ligand sensitive functional activity of the $\sigma 1 / \mathrm{BiP}$ complex depends on the complex lipid environment of the MAM or if unidentified protein partners are involved. A number of studies have demonstrated that detergent solubilized tissues yield $\sigma 1$ complexed with unidentified lipids and/or proteins [29-32]. As a general rule solubilization conditions play a significant role in determining the composition of membrane lysates [33]; therefore, specific detergents and conditions (e.g. temperature and time) utilized to isolate the $\sigma 1 / \mathrm{BiP}$ complex may determine whether or not lipids or cofactors that could be necessary for functional activity are co-isolated.

Recent studies by Hayashi and Fujimoto [34] rigorously characterized the lipid components of MAM and demonstrated that they correspond to the $\sigma 1$ receptor containing detergent resistant microdomains (DRMs) obtained following solubilization with Tx-114 [34]. This series of studies also showed that cholesterol and ceramides serve to anchor $\sigma 1$ at the MAM, and that solubilized $\sigma 1$ preferentially associates with ceramides. Work by Palmer et al. [35] also supports an intimate relationship between $\sigma 1$ and cholesterol, where cholesterol binding domains in $\sigma 1$ form part of the putative ligand binding site [35].

With regards to the possibility of the involvement of unidentified protein partners or cochaperones in the $\sigma 1 / \mathrm{BiP}$ complex, $\sigma 1$ has been reported to directly associate with a number of proteins including: $\mathrm{K}^{+}$channels [5], $\mathrm{IP}_{3}$ type 3 receptors, ankyrin proteins $[3,4]$, voltage gated Ltype $\mathrm{Ca}^{2+}$ channels [9] and acid-sensing ion channels [36]. In each of these studies coprecipitation provided evidence of a direct protein-protein interaction with $\sigma 1$ receptors. Hayashi and $\mathrm{Su}$ [3] also reported detecting small amounts of unidentified proteins in their immunoprecipitations of $\sigma 1 / \mathrm{BiP}$ from $\mathrm{CHO}$ cells but it is not known if these participate in the $\sigma 1 / \mathrm{BiP}$ interaction. Therefore, there is the possibility that additional unidentified protein partners 
could be involved in the interaction of $\sigma 1$ and $\mathrm{BiP}$ which would dictate that activity assays focus on biologically derived proteins as opposed to recombinant proteins.

A very recent study by Ha et al. [15] using RGC-5 cells with a co-immunoprecipitation assay similar to that reported by Hayashi and $\mathrm{Su}[3]$ showed that the $\sigma 1 / \mathrm{BiP}$ interaction is observed concurrently with phosphorylation of $\sigma 1$ [15]. The authors assert that the $\sigma 1 / \mathrm{BiP}$ interaction is modulated by phosphorylation of $\sigma 1$, as evidenced by their observations that: 1) oxidative stress increased the level of $\sigma 1 / \mathrm{BiP}$ complexes and resulted in increased phosphorylation of serine on $\sigma 1$ receptors (Ser117 and/or Ser192), and 2) application of (+)-pentazocine prior to oxidative stress returned the amount of complex to baseline levels and prevented serine phosphorylation [15]. It is not clear from these studies if formation of the complex requires phosphorylation or if phosphorylation occurs as a result of complex formation. This is the first report that regulatory control of $\sigma 1$ receptors may be influenced by its phosphorylation state. If phosphorylation is required for a $\sigma 1 / \mathrm{BiP}$ interaction this has significant implications for development of an in vitro assay based on either purified recombinant proteins or cell membrane derived preparations. However, Hayashi and Su's demonstration that the recombinant GST-Sig-1R116-223 construct was able to precipitate recombinant $\mathrm{BiP}$ or endogenous $\mathrm{BiP}$ from crude homogenates of rat tissues suggests that a $\sigma 1 / \mathrm{BiP}-$ like complex can form in simple model systems [3].

In the present study Alphascreen was evaluated with a control peptide and with purified tagged recombinant proteins in buffer solutions and with added detergent and/or lipid. Supporting studies were performed in an ELISA (enzyme linked immunosorbent assay) format with solubilized rat liver and $\mathrm{CHO}$ cell lysates. The goal of these efforts was to isolate and detect the $\sigma 1 / \mathrm{BiP}$ complex reported by Hayashi and $\mathrm{Su}[3]$ and determine if an immunologically based functional assay could be developed that exploited the disruption of this interaction as a read-out of $\sigma 1$ receptor activation by agonist ligands. The goals of these studies were: 1) to determine if Alphascreen provided a viable platform for development of a $\sigma 1$ activity assay, 2) to determine if such an assay could be performed with recombinant affinity tagged fusion proteins in buffer or simple detergent or lipid solutions, and 3) to determine if solubilized rat liver P2 or $\mathrm{CHO}$ cell lysates could serve as suitable sample sources for an Alphascreen based assay. 


\subsection{Materials and Methods}

\subsubsection{Chemicals and reagents and materials}

$\left[{ }^{3} \mathrm{H}\right](+)$-Pentazocine (specific activity $=29 \mathrm{Ci} / \mathrm{mmol}$ ) was purchased from Perkin Elmer (Boston, MA). (+)-Pentazocine, 1,3-di-o-tolylguanidine (DTG), and haloperidol were purchased from Sigma-Aldrich (St. Louis, MO). NE100 (4-methoxy-3-(2-phenylethoxy)- $N, N$ dipropylbenzeneethanamine hydrochloride) was from Tocris Bioscience (Ellisville, MO). $1 \mathrm{~N}$ Hydrochloric acid, Microscint-20, Costar Untreated polystyrene plates (9017), Costar High Bind polystyrene plates (9018), Costar Easy Wash High Bind polystyrene plates (3369), Costar Untreated polyvinylchloride plates (2797), 100X HALT protease inhibitor cocktail and Unifilter96 GF/B filter plates were purchased from Fisher Scientific (Pittsburgh, PA). Dulbecco's phosphate buffered saline without $\mathrm{Ca}^{2+}$ or $\mathrm{Mg}^{2+}$ (DPBS without $\mathrm{Ca}^{2+} \mathrm{Mg}^{2+}$ ) was from Invitrogen (Carlsbad, CA). Recombinant active human 6X-His BiP (AB78432) was obtained from Abcam (Cambridge, MA), and the purified human $\sigma 1-m y c-F L A G$ protein (TP301206) was from Origene (Rockville, MD). Alphascreen nickel-chelate donor beads and FLAG-Ab acceptor beads were from Perkin Elmer (Waltham, MA). Anti-FLAG M2 affinity gel, 3XFLAG peptide, aminoterminal FLAG-BAP fusion protein, Cellytic $\mathrm{M}$, CHAPS, $\mathrm{CaCl}_{2}$, tris(hydroxymethyl)aminomethane (Tris), fatty acid free bovine serum albumin (BSA), 2,2'azino-bis(3-ethylbenzothiazoline-6-sulfonic acid) diazonium salt (ABTS), phosphate-citrate buffer, Tris buffered saline with Tween 20, pH 8 (Tris-Tween, T9039) and the 30\% hydrogen peroxide solution were from Sigma-Aldrich. Mouse anti-human BiP aa525-628 (BD610979) antibody was from BD Transduction Lab (Franklin Lakes, NJ). Rabbit anti-human BiP aa24-43 (AB32618) and rabbit anti-rat $\sigma 1$ "c-terminal" (AB53852) were from Abcam. A custom chicken anti-rat $\sigma 1$ aa65-78 antibody was purchased from Aves laboratories (Tigard, OR). The mouseanti-FLAG M2 antibody (F1804), horse radish peroxidase (HRP) conjugated goat-anti-mouse antibody (A9917) and HRP conjugated goat-anti-rabbit antibody (A0545) were from SigmaAldrich. The biotin conjugated rabbit-anti-chicken antibody (G2891) was from Fisher Scientific and was used in conjunction with streptactin-HRP from Bio-rad (Hercules, CA). Precision Plus Protein Western C molecular weight markers were also from Bio-rad. SuperSignal West Pico Chemiluminescent Substrate was from Fisher Scientific. 


\subsubsection{Test compound solutions}

Stock solutions of (+)-pentazocine, DTG, haloperidol, and NE100 were prepared in DMSO. Dilutions for use in preparation of samples were made in assay buffers specific to the assay in which they were used.

\subsubsection{CHO cell culture}

CHO-K1 cells were obtained from the American Type Culture Collection (Lot number, 58078551, passage number unknown, ATCC; Rockville, MD). Cells were grown in F-12K medium (ATCC) supplemented with 5\% heat inactivated fetal bovine serum (Sigma-Aldrich), 100 units/ml penicillin and $100 \mu \mathrm{g} / \mathrm{ml}$ streptomycin (Sigma-Aldrich). Cells were maintained at $37^{\circ} \mathrm{C}$ in $5 \% \mathrm{CO}_{2}$. Passage of cells was performed using $0.25 \%$ trypsin/ $0.5 \mathrm{mM}$ EDTA (Invitrogen; Carlsbad, CA).

\subsubsection{CHO cell lysates}

CHO cell lysates were prepared in 0.2\% CHAPS, 2\% CHAPS, or in CelLytic M. For each cell

lysate, cells from two sub-confluent $175 \mathrm{~cm}^{2}$ flasks were harvested in DPBS without $\mathrm{Ca}^{2+} / \mathrm{Mg}^{2+}$ and centrifuged at $500 \mathrm{x} \mathrm{g}$ for $5 \mathrm{~min}$ at $4{ }^{\circ} \mathrm{C}$. For lysates prepared in CHAPS, solutions containing $2.5 \mathrm{ml}$ of $0.2 \%$ or $2 \%$ CHAPS in $50 \mathrm{mM}$ Tris, $\mathrm{pH} 7.4$ with $1 \mathrm{X}$ HALT were added to pelleted cells. For lysates prepared in CelLytic M, a solution of CelLytic M containing 1X HALT in a total volume of $2.5 \mathrm{ml}$ was added to pelleted cells. The re-suspended cells were rocked for $1 \mathrm{~h}$ at $4{ }^{\circ} \mathrm{C}$ followed by centrifugation at $16,000 \mathrm{x} \mathrm{g}$ for $15 \mathrm{~min}$ at $4{ }^{\circ} \mathrm{C}$. Supernatents were transferred to clean tubes and maintained on ice until use.

\subsubsection{Rat liver and Rat brain P2}

Rat liver and rat brain P2 homogenates were prepared from frozen tissues obtained from PelFreeze (Rogers, AR). Tissues were homogenized batch-wise with a Potter-Elvehjem homogenizer (5-10 strokes with motor driven Teflon pestle) in ice-cold $10 \mathrm{mM}$ Tris-sucrose buffer (0.32 $\mathrm{M}$ sucrose in $10 \mathrm{mM}$ Tris, $\mathrm{pH}$ 7.4) using $10 \mathrm{ml}$ buffer per $\mathrm{g}$ of tissue with $\sim 3 \mathrm{~g}$ of tissue per batch. Homogenates from multiple batches were combined and centrifuged for $10 \mathrm{~min}$ at $1,000 \mathrm{x} \mathrm{g}$, at $4{ }^{\circ} \mathrm{C}$. Supernatants were decanted, combined and centrifuged for $15 \mathrm{~min}$ at $31,000 \mathrm{x} \mathrm{g}$, at $4{ }^{\circ} \mathrm{C}$. To reduce levels of bound endogenous ligand(s) the resulting P2 membrane 
was washed as follows: 1) pellets were re-suspended in $10 \mathrm{mM}$ Tris, $\mathrm{pH} 7.4 \mathrm{using} 3 \mathrm{ml}$ buffer per gram of wet tissue, 2) the resulting suspension was incubated for $30 \mathrm{~min}$ at $25^{\circ} \mathrm{C}, 3$ ) following incubation, the suspension was centrifuged for $15 \mathrm{~min}$ at $31,000 \mathrm{xg}$, at $4{ }^{\circ} \mathrm{C}$. The resulting pellets were re-suspended in $10 \mathrm{mM}$ Tris, $\mathrm{pH} 7.4$ buffer at a final concentration of $1 \mathrm{~g}$ starting tissue weight/1.5 ml. Tissue preparations were aliquoted in $1 \mathrm{ml}$ portions and stored at $80{ }^{\circ} \mathrm{C}$. The Bradford assay was used to quantitate protein concentration [37].

\subsubsection{CHAPS solubilized rat liver and rat brain $P 2$}

Rat liver and rat brain P2 were solubilized in 0.2\% CHAPS as follows. A $1 \mathrm{ml}$ aliquot of liver or brain P2 containing $10 \mathrm{mg} / \mathrm{ml}$ total protein was centrifuged at $500 \mathrm{x} \mathrm{g}$ for $5 \mathrm{~min}$. Following aspiration of the supernatant, $1 \mathrm{ml}$ of $0.2 \%$ CHAPS in $50 \mathrm{mM}$ Tris, $\mathrm{pH} 7.4$ with 1X HALT was added to the resulting pellet. The sample was incubated for $60 \mathrm{~min}$ with rocking at $4{ }^{\circ} \mathrm{C}$ and subsequently centrifuged for $15 \mathrm{~min}$ at $31,000 \mathrm{x} \mathrm{g}$, at $4{ }^{\circ} \mathrm{C}$. The supernatant was transferred to a clean polypropylene tube and maintained on ice until use.

\subsubsection{Radioligand binding of rat liver P2 versus solubilized rat liver P2}

A standard radioligand binding experiment was performed to compare binding of $\left[{ }^{3} \mathrm{H}\right](+)$ pentazocine to "native" and solubilized rat liver P2 samples. To determine total binding, $5 \mathrm{nM}$ $\left[{ }^{3} \mathrm{H}\right](+)$-pentazocine was added to $25 \mu \mathrm{g}$ (total protein) samples of native and CHAPS solubilized rat liver in a total volume of $0.5 \mathrm{ml}$ of $50 \mathrm{mM}$ Tris, $\mathrm{pH}$ 8. Samples for the determination of nonspecific binding were prepared by addition of $10 \mu \mathrm{M}$ haloperidol. Total and non-specific binding samples were prepared and processed in parallel. Samples were incubated for $2 \mathrm{~h}$ at $25^{\circ} \mathrm{C}$ and filtered through Perkin Elmer Unifilter GF/B filter plates using a Connectorate 96-well harvester (Dietikon, Switzerland). Samples were washed 5 times with $0.2 \mathrm{ml}$ of $10 \mathrm{mM}$ Tris, $\mathrm{pH} 8$ and air dried prior to adding scintillation cocktail. Filter plates were soaked in $0.5 \%$ polyethyleneimine (PEI) for $30 \mathrm{~min}$ prior to use to reduce non-specific binding. Processed samples were counted on a Perkin Elmer Microbeta2 2450 microplate counter (Waltham, MA), in the Unifilter plate, following a $2 \mathrm{~h}$ incubation with $40 \mu \mathrm{l}$ Microscint-20 cocktail per well. 


\subsubsection{ELISA assays}

A sandwich-type ELISA was utilized to test for capture and detection of the $\sigma 1 / \mathrm{BiP}$ complex present in CHAPS solubilized rat liver and rat brain P2. Four different sample plate types were tested, including plates of different base plastic and treated and untreated plates (Costar product numbers 2797, 3369, 9017 and 9018). Control samples consisted of adding buffer alone to antibody coated wells at the appropriate step of the assay. Rat brain P2 served as a second control as it is known to contain approximately $1 / 6$ the number of $\sigma 1$ receptors per mg of protein compared to rat liver $\mathrm{P} 2$, so would be expected to generate 1/6 the signal derived from rat liver P2. The general assay scheme is shown schematically in Figure 1. Sample plates were coated with $\sigma 1$ antibody (Aves custom), $100 \mu \mathrm{l} /$ well, containing 1 or $10 \mu \mathrm{g} / \mathrm{ml}$ antibody in carbonate buffer, $\mathrm{pH}$ 9.6. Plates were incubated overnight at $4{ }^{\circ} \mathrm{C}$. All incubations were accompanied by gentle agitation on an orbital plate shaker. Following a PBS wash, plates were blocked with 1\% BSA in carbonate buffer, $200 \mu \mathrm{l} /$ well. Following incubation for $1 \mathrm{~h}$ at room temperature (RT), plates were washed with PBS and samples of $0.2 \%$ CHAPS solubilized liver or brain P2 containing $100 \mu \mathrm{g}$ total protein in $100 \mu \mathrm{l} /$ well, were added. Control wells were prepared by addition $0.2 \%$ CHAPS, $100 \mu \mathrm{l} /$ well. To test for ligand and $\mathrm{Ca}^{2+}$ sensitivity, $10 \mu \mathrm{l}$ of $10 \mathrm{X}$

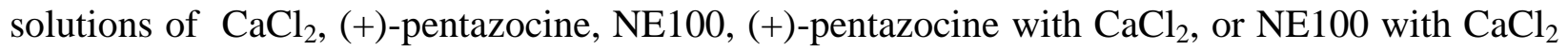
were added to samples in wells for final concentrations of $1 \mathrm{mM} \mathrm{CaCl}_{2}$ and/or $1 \mu \mathrm{M}$ ligand; for control samples $10 \mu \mathrm{l}$ buffer was added. Following incubation for $1 \mathrm{~h}$ at RT, plates were washed with PBS containing $1 \mathrm{mM} \mathrm{CaCl} 2\left(\mathrm{PBS} / \mathrm{Ca}^{2+}\right)$ followed by addition of $100 \mu \mathrm{l}$ of a $1 / 1000$ dilution of mouse anti-human $\mathrm{BiP}$ aa525-628 antibody (BD610979) or rabbit anti-human BiP aa24-43 antibody (AB32618). Following incubation for $1 \mathrm{~h}$ at RT, plates were washed with PBS/Ca ${ }^{2+}$ and $100 \mu \mathrm{l}$ of a 1/10,000 dilution of HRP conjugated goat-anti-mouse or goat-antirabbit antibody was added. Following incubation for $1 \mathrm{~h}$ at RT plates were washed with $\mathrm{PBS} / \mathrm{Ca}^{2+}$ and $100 \mu \mathrm{l} /$ well ABTS in phosphate-citrate buffer containing hydrogen peroxide was added. Following 30-60 min of light agitation, plates were read on a Biotek Multi-plate reader (Winooski, VT) at $405 \mathrm{nM}$. The ABTS solution was prepared by dissolving 1 tablet (Sigma $\mathrm{P} 4809$ ) in $100 \mathrm{ml}$ of $0.05 \mathrm{M}$ phosphate-citrate buffer, $\mathrm{pH} 5.0$ and adding $25 \mu \mathrm{l}$ of fresh $30 \%$ hydrogen peroxide. To confirm that the ABTS/HRP reaction was patent, 10 or $20 \mu$ aliquots of HRP secondary antibody solutions were added to $100 \mu \mathrm{l}$ /well of ABTS reagent solution. 


\subsubsection{Capture of $\sigma 1 / B i P$ complex on antibody coated polystyrene plates}

Antibodies for $\sigma 1$ and $\mathrm{BiP}$ were passively adsorbed to polystyrene plates and tested for capture of $\sigma 1, \mathrm{BiP}$ or the $\sigma 1 / \mathrm{BiP}$ complex from $\mathrm{CHO}$ cell lysates. Treated polystyrene sample plates (Costar 9018) were coated with both available $\sigma 1$ antibodies (AB53852, Aves custom) and both BiP antibodies (BD610979, AB53852) by incubating $100 \mu 1$ of $2 \mu \mathrm{g} / \mathrm{ml}$ solutions of antibody in carbonate buffer, $\mathrm{pH} 9.6$, overnight at $4{ }^{\circ} \mathrm{C}$. Plates were washed with PBS, blocked with $1 \%$ BSA in PBS for $1 \mathrm{~h}$, and washed with PBS prior to application of CHO cell lysates. CHO cell lysates, $100 \mu \mathrm{l}$, were incubated in coated wells for $1 \mathrm{~h}$ at RT. Following incubation, wells were washed with $1 \mathrm{mM} \mathrm{CaCl} 2$ in PBS. For PAGE/western blot analysis samples were desorbed from plates by addition of $5 \mu 1$ of $1 \mathrm{X}$ Laemmli buffer ( $125 \mathrm{mM}$ Tris, $\mathrm{pH}$ 6.8, $4 \%$ sodium dedecyl sulfate, $20 \%$ glycerol and $0.004 \%$ bromophenol blue) followed by incubation for $5 \mathrm{~min}$ at ambient temperature with shaking. Four wells for each sample were prepared and combined for loading on gels. Crude lysates were diluted 1:1 with $2 \mathrm{X}$ Laemmli and $10 \mu 1$ was loaded per lane. Prior to loading on gels all samples were incubated for $5 \mathrm{~min}$ in boiling water.

\subsubsection{Alphascreen assays}

Preliminary studies focused on demonstrating that the proposed assay scheme could detect the interaction of purified $\sigma 1$-FLAG and 6XHis proteins utilizing a nickel chelate donor bead and an anti-FLAG coated acceptor bead. The general assay scheme shown in Figure 2A is an adaptation of the scheme proposed for detection of $\sigma 1$-FLAG and endogenous BiP as shown in Figure 2B. A control peptide comprised of 6XHis and the FLAG sequence separated by a 12 amino acid linker (HHHHHH-GASGSAASGSAG-DYKDDDDK) was utilized to determine starting conditions, define expected signal ranges, and to determine if sigma ligands, buffers or other additives had an effect on the signal generated by the interaction of the peptide with the Alphascreen beads. Following determination of appropriate starting conditions, samples containing purified recombinant $\sigma 1-\mathrm{FLAG}$ and $6 \mathrm{XHiS} \mathrm{BiP}$ were prepared to determine if a $\sigma 1 / \mathrm{BiP}$ interaction could be detected, and if the complex was detected, to test its sensitivity to $\mathrm{Ca}^{2+}$, sigma ligands and EDTA. Samples for all Alphascreen studies were prepared in duplicate unless otherwise indicated and were read on an Envision Multilabel Microplate Reader (Perkin Elmer, Waltham, MA). All data reported from Alphascreen studies represent the average of duplicate determinations for each condition tested. 


\subsubsection{Alphascreen with control peptide}

To establish starting conditions and test the performance of the proposed Alphascreen scheme (as illustrated in Figure 2B), preliminary experiments were performed with a control peptide comprised of an N-terminal 6XHis tag, and a C-terminal FLAG tag, separated by a 12 amino acid linker (HHHHHH-GASGSAASGSAG-DYKDDDDK). Samples were prepared in 1X Alphascreen Universal buffer (PBS pH 7.2 with $0.05 \%$ BSA, "AU buffer") and contained 20 $\mu \mathrm{g} / \mathrm{ml}$ Alphascreen donor and acceptor beads (nickel-chelate donor and FLAG-Ab acceptor) and varying concentrations of the $6 \mathrm{X}$-His/FLAG control peptide in a total volume of $50 \mu \mathrm{l} / \mathrm{sample}$. To confirm that the signal observed was due to the specific interaction of the control peptide with the donor and acceptor beads additional samples were prepared containing $200 \mathrm{nM}$ control peptide with $200 \mathrm{nM}$ FLAG peptide or $200 \mathrm{nM}$ 6XHis-BiP as competitors for binding to the respective beads. To confirm that the interactions of the tags with their respective beads were insensitive to sigma test ligands or added $\mathrm{Ca}^{2+}$, additional samples containing $200 \mathrm{nM}$ control peptide were prepared containing $10 \mathrm{nM}$ DTG, (+)-pentazocine, haloperidol, NE100, or $1 \mathrm{mM}$ $\mathrm{CaCl}_{2}$.

\subsubsection{Alphascreen with purified $\sigma 1-F L A G$ and 6 XHis-BiP fusion proteins}

Assays with the purified tagged recombinant proteins were performed using conditions determined with the control peptide. Samples contained $20 \mu \mathrm{g} / \mathrm{ml}$ Alphascreen donor and acceptor beads, $0.5 \mathrm{mM} \mathrm{CaCl}_{2}$ and $50 \mathrm{nM} \sigma 1$-FLAG and/or 6XHis-BiP, in AU buffer in a total volume of $50 \mu \mathrm{l} /$ well. Sample components were preincubated for one hour at RT in a volume of $30 \mu \mathrm{l}$ prior to the addition of $20 \mu \mathrm{l}$ of a solution containing $50 \mu \mathrm{g} / \mathrm{ml}$ of both donor and acceptor Alphascreen beads in AU buffer. Additional samples were prepared containing EDTA or sigma ligands to test their effect on signal levels. Peptide control samples were also prepared containing peptide or peptide with added sigma ligand or EDTA. To test the effect of added CHAPS detergent or phosphatidylcholine (PC), another set of samples were prepared containing $0.2 \%$ CHAPS, $0.3 \mathrm{mg} / \mathrm{ml}$ PC or CHAPS + PC (in AU buffer). 


\subsubsection{Capture of $\sigma$ 1-FLAG on FLAG-antibody affinity bead / FLAG pulldown assay}

The purpose of this assay was to test if recombinant o1-FLAG can function in an immunoprecipitation assay similar to the GST fusion protein (GST-Sig-1R116-223) pulldown assay described by Hayashi and Su [3]. Samples contained $30 \mu \mathrm{g}$ anti-FLAG M2 beads, $200 \mathrm{ng}$ б1-FLAG, $500 \mathrm{ng} 6$ XHis-BiP, $200 \mathrm{ng}$ o1-FLAG + $500 \mathrm{ng} 6$ XHis-BiP or $200 \mathrm{ng}$ of the control BAP-FLAG fusion protein in a total volume of $1 \mathrm{ml}$ of binding buffer $(0.5 \%$ Nonidet P-40, 50 $\mathrm{mM}$ Tris, $\mathrm{pH} 7.4$ and $2 \mathrm{mM} \mathrm{Ca}^{2+}$ ). Samples were incubated overnight with rocking at $4{ }^{\circ} \mathrm{C}$. Beads were washed with three $500 \mu \mathrm{l}$ aliquots of binding buffer with centrifugation at $8,000 \mathrm{x} \mathrm{g}$ x $30 \mathrm{sec}$ between washes to facilitate complete removal of wash buffer with a crimped pipet tip. Following the final wash beads were eluted with $20 \mu 1$ of Laemmli buffer with immersion in boiling water for $5 \mathrm{~min}$. Non-immunoprecipitated control samples of each protein (and $\sigma 1$-FLAG with 6XHis-BiP) were prepared in Laemmli buffer and boiled as for immunoprecipitated samples.

\subsubsection{Western blots}

Samples from antibody coated polystyrene plates and the FLAG pulldown assay were separated by SDS-PAGE and transferred to PVDF membranes for Western blot analysis. To detect $\sigma 1, \sigma 1$ FLAG or BiP, the PVDF membranes were incubated with the respective primary antibodies at the indicated dilutions: chicken-anti-rat $\sigma 1$ (Aves custom, 1:8000), mouse-anti-FLAG M2 (F1804, 1:1000), mouse-anti-human BiP (BD610979, 1:10,000) or rabbit-anti-human BiP (AB32618, 1:10,000). The secondary antibodies, biotin conjugated rabbit-anti-chicken (G2891), HRP goat-anti-mouse (A9917), or HRP goat-anti-rabbit (A0545), were used at a 1:50,000 dilution. Streptactin-HRP was used at a 1:12,500 dilution. Incubations with antibodies were typically $1 \mathrm{~h}$ at RT with agitation. Washes were performed with Tris-Tween and antibody solutions contained $1 \%$ dried milk. Proteins were visualized by chemiluminescence with SuperSignal West Pico Chemiluminescent Substrate (Fisher Scientific). 


\subsection{Results}

\subsubsection{Radioligand binding of solubilized rat liver $P 2$}

Rat liver P2 homogenate solubilized in 0.2\% CHAPS resulted in an extract with similar binding capacity relative to unsolubilized membrane. Figure 3 shows binding results for non-specific and total binding for rat liver P2 versus rat liver P2 solubilized in 0.2\% CHAPS. This material was used for the ELISA-format assays outlined below.

\subsubsection{ELISA assays}

Attempts to run ELISA assays with the Aves $\sigma 1$ antibody passively absorbed to the plate, using solubilized rat liver P2 as sample and "end-point" detection, were unsuccessful. Eight trials were attempted with varying samples and sample plates including: 1) liver P2 and buffer control, 2) both liver P2 and brain P2 samples in addition to buffer control, 3) with or without addition of sigma ligands, and 4) with or without $\mathrm{CaCl}_{2}$, in combination with four different sample plates (Costar 2797, 3369, 9017 or 9018). For all conditions tested either no difference in signal was observed for the different sample combinations within each trial or if differences were observed they were not reproducible between trials.

5.4.3 Capture of $\sigma 1$ or BiP from CHO cell lysates on polystyrene plate coated with $\sigma 1$ or BiP antibodies

No capture of $\sigma 1$ or $\mathrm{BiP}$ or evidence of capture of a $\sigma 1 / \mathrm{BiP}$ complex was observed following application of $\mathrm{CHO}$ cell lysates to polystyrene plates coated with $\sigma 1$ or BiP antibodies. Figure 4 shows the Western blot of sample wells eluted with gel loading buffer following application of $\mathrm{CHO}$ cell lysates to plates containing $\sigma 1$ antibodies and probed with the Aves $\sigma 1$ antibody. No bands for $\sigma 1$ were observed for samples eluted from the antibody coated plates. Similarly when the gel was re-probed with either BiP antibody no bands were observed corresponding to BiP; however, neither of the $\mathrm{BiP}$ antibodies produced signals on any of the blots produced over the course of these studies. The plates coated with $\mathrm{BiP}$ antibodies gave similar results as those coated with $\sigma 1$ antibodies, i.e., no bands were observed for $\sigma 1$. There were notable differences in the profile observed for the lysates prepared with the different solubilization agents, where the $0.2 \%$ CHAPS sample contained one band corresponding to $\sigma 1$, and 2\% CHAPS and CelLytic M 
samples contained an additional unidentified band at $\sim 75 \mathrm{kDa}$. The band for $\sigma 1$ was most intense for samples prepared with CelLytic M; the unidentified $75 \mathrm{kDa}$ band was also most prominent in the CelLytic M lysate sample.

\subsubsection{Alphascreen with 6XHis/FLAG control peptide}

The addition of the 6XHis/FLAG control peptide to Alphascreen beads generated signal in a concentration-dependant manner as shown in Figure 5. The concentration-response function shows a wide dynamic range spanning $\sim 3 \mathrm{nM}$ to $\sim 3 \mu \mathrm{M}$ added peptide. As shown in Figure 6, the signal generated in the presence of $200 \mathrm{nM}$ control peptide was unaffected by the addition of any of the sigma ligands tested at a $10 \mu \mathrm{M}$ concentration, suggesting that sigma ligands have no effect on the association of the fusion tags with their respective capture bead or any detrimental effect on the signal. Similarly the addition of $\mathrm{CaCl}_{2}$ had no effect on the signal. Because added $\mathrm{Ca}^{2+}$ is required to facilitate the $\sigma 1 / \mathrm{BiP}$ interaction it was important that it had little or no effect on the signal. Addition of $6 \mathrm{XHis}-\mathrm{BiP}$ or $3 \mathrm{X}$-FLAG peptide at a concentration equal to the concentration of added control peptide ( $200 \mathrm{nM})$ reduced the signal substantially as would be predicted if signal was produced by the specific interaction of the control peptide tags with their respective Alphascreen beads.

\subsubsection{Alphascreen with ol-FLAG and 6XHis-BiP fusion proteins in Alphascreen Universal buffer}

As shown in Table 1, incubation of Alphascreen beads with o1-FLAG in AU buffer in the absence of 6xHis-BiP generated a substantial fluorescent signal. The same level of signal was observed in the sample prepared with $\sigma 1-\mathrm{FLAG}+6 \mathrm{xHis-BiP}$; this signal was reduced to background levels by the addition of EDTA. These results suggest that $\sigma 1$ interacts with the nickel-chelate donor bead directly and that this interaction can be mitigated upon chelation of the bead bound nickel by EDTA. Divalent cations are known to allosterically inhibit binding of $\left[{ }^{3} \mathrm{H}\right](+)$-pentazocine to $\sigma 1$ [38]. However, it is not certain that the current situation is the result of

$\sigma 1$ binding to $\mathrm{Ni}^{2+}$ chelated to the bead, or is the result of another non-specific interaction, or aggregation. The addition of sigma agonist $((+)$-pentazocine) or antagonist (NE-100) did not appear to have an effect on the Alphascreen signal for samples containing o1-FLAG + 6xHisBiP. No difference was observed in samples containing $\sigma 1-\mathrm{FLAG}+6 \mathrm{xHis}-\mathrm{BiP}$ in the presence or absence of $\mathrm{CaCl}_{2}$. The addition of sigma ligands also had no effect on the fluorescent signal 
generated in the peptide control samples. The exclusion of $\mathrm{CaCl}_{2}$ from the control peptide sample had no effect on the signal relative to samples prepared with $0.5 \mathrm{mM} \mathrm{CaCl}_{2}$. The addition of EDTA to the peptide control sample reduced the fluorescent signal substantially suggesting the signal observed in the absence of EDTA is due to the interaction of the control peptide with the chelated $\mathrm{Ni}^{2+}$ of the donor beads and with the acceptor beads.

\subsubsection{Alphascreen with ol-FLAG and 6XHis-BiP fusion proteins in CHAPS and/or added phosphatidylcholine}

Samples run in the previous experiment were prepared in $\mathrm{PBS} / \mathrm{CaCl}_{2}$ buffer. To test if CHAPS or added lipid could mitigate the interaction of $\sigma 1$-FLAG with the donor bead and/or promote the specific interaction of $\sigma 1$-FLAG and 6XHis-BiP fusion proteins, a similar Alphascreen experiment was performed as previously described. The overall signal for all samples prepared with CHAPS or PC was lower relative to samples prepared in the PBS buffer (Alphascreen Universal buffer), but signal due to 61 -FLAG alone relative to $\sigma 1$-FLAG +6 XHis-BiP was similar with all buffer solutions. Interestingly, for samples prepared with 0.2\% CHAPS, PC or CHAPS/PC, the addition of sigma ligands increased the signal relative to samples containing $\sigma 1$ FLAG or $\sigma 1-F L A G+6$ XHis-BiP alone. Samples prepared in CHAPS/PC gave a similar signal for all samples containing either or both of the recombinant proteins in the absence of sigma ligands. The signal due to $6 \mathrm{XHis-BiP}$ alone in this buffer suggests additional non-specific interactions occur in this assay matrix relative to the other matrices tested.

\subsubsection{FLAG Pulldown with $\sigma 1-F L A G$ and FLAG affinity matrix}

Pulldown of recombinant $\sigma 1$-FLAG from a solution of $0.5 \%$ Nonidet P-40, $50 \mathrm{mM}$ Tris, $\mathrm{pH} 7.4$ and $2 \mathrm{mM} \mathrm{Ca}^{2+}$ was unsuccessful, but the bacterial alkaline phosphatase-FLAG (BAP-FLAG) fusion protein used as a control sample was successfully precipitated in this system. Figure 7 shows that samples containing $\sigma 1-\mathrm{FLAG}$ or $\sigma 1-\mathrm{FLAG}+\mathrm{His}-\mathrm{BiP}$ loaded directly on the gel gave a strong signal for $\sigma 1$-FLAG at $\sim 25 \mathrm{kDa}$ following blotting of the PVDF membrane with the anti-FLAG antibody. Similar samples subjected to immunoprecipitation using the same buffer used by Hayashi et al. [3] for successful pulldowns of BiP with the GST-fusion system do not show bands corresponding to $\sigma 1$-FLAG. The BAP-FLAG control sample was successfully immunoprecipitated in this buffer as evidenced by a strong band at $50 \mathrm{KDa}$ for both the sample 
loaded directly on the gel and for the immunoprecipitated sample.

\subsection{Discussion}

The results from these preliminary experiments did not establish that an Alphascreen assay based on the interaction of $\sigma 1$ and $\mathrm{BiP}$ would result in a viable system for quantitation of the functional activity of $\sigma 1$ ligands. However, the experiments performed to test this system did provide valuable data for future studies. The model Alphascreen scheme originally intended for use with CHO cells expressing o1-FLAG yielded equivocal results with recombinant proteins due to an apparent interaction of the $\sigma 1-F L A G$ protein with the Alphascreen nickel-chelate donor bead. This interaction may be the result of association of the $\sigma 1$ receptor with the chelated $\mathrm{Ni}^{2+}$. Conditions which might be expected to disrupt this interaction, e.g. high $\mathrm{Ca}^{2+}$ concentrations, are also likely to affect the interaction of the o1-FLAG protein with $\mathrm{BiP}$ to such an extent that the agonist sensitive behavior of the $\sigma 1 / \mathrm{BiP}$ complex would be masked. Tests of the proposed Alphascreen scheme with the control peptide produced a dose-dependant signal that was unaffected by high concentrations of sigma ligands or added $\mathrm{CaCl}_{2}$, suggesting that under appropriate conditions Alphascreen may still be a viable format for a functional assay based on the $\sigma 1 / \mathrm{BiP}$ interaction. Despite the problems encountered, the theoretical basis for the assay remains compelling. Recent studies showing successful immunoprecipitation of the $\sigma 1 / \mathrm{BiP}$ complex from crude cell lysates of wild-type RGC-5 cells [15] suggest that the endogenously expressed $\sigma 1 / \mathrm{BiP}$ complex can be isolated with relative ease with the proper combination of cells, detergent, and $\sigma 1$ antibody. This is in contrast to the necessity of isolating MAM to observe the complex present in wild-type CHO cells solubilized in CHAPS [3]. Because we were unsuccessful in our attempts to isolate MAM, this simplified method for isolating a patent $\sigma 1 / \mathrm{BiP}$ complex from crude cell lysates may hasten future efforts to develop a functional assay based on the $\sigma 1 / \mathrm{BiP}$ interaction.

Our initial intention was to utilize cell lysates from $\mathrm{CHO}$ cells expressing 61 -FLAG as input for the Alphascreen assay, similar to Hayashi and Su's original work with $\mathrm{CHO}$ cells expressing $\sigma 1$ EYFP [3], but attempts to clone the vector were unsuccessful. MAM was also an intended input for Alphascreen, and efforts to isolate MAM from rat liver P2 and CHO cells were made, but no 
bands were observed on Western blots, corresponding to the $\sigma 1$ receptor, in the isolated fractions. Additionally, radioligand binding suggested that the isolates were not materially different from the P2 fraction that served as the starting material for MAM isolation; no enrichment of binding was observed on a per mass basis compared to the P2 starting material. Because efforts to isolate a fraction that could unequivocally be identified as MAM were unsuccessful, the experiments with rat liver $\mathrm{P} 2$ and $\mathrm{CHO}$ cell lysates were performed as described below. Recombinant $\sigma 1-F L A G$ became commercially available soon after these problems were encountered, enabling studies to assess the basic functionality of Alphascreen with purified $\sigma 1$ and $\mathrm{BiP}$ proteins.

ELISA methods were utilized to make a preliminary assessment of the feasibility of capturing $\sigma 1$ or the $\sigma 1 / \mathrm{BiP}$ complex from rat liver $\mathrm{P} 2$ with our custom $\sigma 1$ antibody passively adsorbed to ELISA plates. This would support use of endogenously expressed sigma receptors in conjunction with our custom $\sigma 1$ antibody in an Alphascreen assay. Rat liver P2 contains a relatively high level of $\sigma 1(\sim 3 \mathrm{pmol} / \mathrm{mg})$; therefore, we believed CHAPS lysates of this material may contain sufficient concentrations of $\sigma 1$ for detection. However, because numerous experiments with the CHAPS solubilized rat liver P2 tested in the proposed sandwich ELISA format resulted in irreproducible data, a more systematic approach was undertaken where multiple $\sigma 1$ and BiP antibodies were tested for capture of their cognate binding partners from $\mathrm{CHO}$ lysates irrespective of the $\sigma 1 / \mathrm{BiP}$ interaction.

Experiments with two different $\sigma 1$ antibodies, and two different BiP antibodies, passively adsorbed to the ELISA plates, failed to effect capture of the $\sigma 1$ receptor from $\mathrm{CHO}$ lysates. Failure to capture $\sigma 1$ with the two $\sigma 1$ antibodies tested may have been the result of the antibodies binding on the plastic surface in an orientation that did not support an interaction with $\sigma 1$. Use of passively adsorbed antibodies is an accepted practice and often yields usable results; however, it is highly dependant on the specific antibody and can result in as little as $3-10 \%$ of bound antibody capable of capturing antigen [39]. Because the total amount of $\sigma 1$ receptor applied to the ELISA plates was $\sim 80$ times greater than the amount that was directly loaded and successfully visualized on the Western blot, this suggests that if even a small fraction of the $\sigma 1$ applied to the plate was captured it should have been detected on the Western blots. It should be 
noted that our custom polyclonal $\sigma 1$ antibody targets a different region (residues 65-78) of the rat $\sigma 1$ receptor than the antibodies successfully employed by Hayashi and $\mathrm{Su}$ (residues 52-69) [3] and $\mathrm{Ha}$ et al. (residues 143-165) [15] in their immunoprecipitation experiments. The Abcam $\sigma 1$ antibody (ab53852) target sequence is proprietary, but is described as targeting the "C-terminal region"; this antibody has been demonstrated to work with Western blotting but has not been validated for use with immunoprecipitation. While our custom $\sigma 1$ antibody has been successfully utilized for Western blots, and for flow cytometry with fixed and permeabilized NG-108 cells (unpublished data produced in our laboratory), it is not known if it is $\sigma 1$ binding competent under other conditions. The Western blots for BiP have been inconclusive over the course of this project; therefore, no conclusion can be made regarding the success or failure to capture BiP.

The Western blots from the above experiments showed that the crude CHO cell lysates prepared in CelLytic M or 2\% CHAPS yielded a different population of sigma receptors than are produced using $0.2 \%$ CHAPS. In the CelLytic and 2\% CHAPS lysates an additional strong band was observed at molecular weight $\sim 75 \mathrm{kDa}$ that may represent a complex of $\sigma 1$ with lipid or protein. This is consistent with reports that different detergents and solubilization conditions result in isolation of different molecular complexes of $\sigma 1$, as determined by gel exclusion chromatography [29-32]. This is relevant because it is not known if a functional $\sigma 1 / \mathrm{BiP}$ complex can be isolated using a wide range of solubilization conditions or if one can be isolated at all. In light of the report by $\mathrm{Ha}$ et al. [15] of immunoprecipitation of a $\sigma 1 / \mathrm{BiP}$ complex from crude lysates of RGC-5 cells, solubilized with a detergent mixture that was substantially different than that utilized by Hayashi and $\mathrm{Su}[3]$, it appears that successful co-precipitation of a $\sigma 1 / \mathrm{BiP}$ complex can be effected from multiple sources with varied detergents. However, because neither group demonstrated the functional activity of the isolated complex with exogenous addition of sigma ligands it is not known if either or both isolates contain the necessary components required of a functional complex.

Assays with Alphascreen were performed with a control peptide and purified recombinant tagged $\sigma 1$ and $\mathrm{BiP}(\sigma 1-\mathrm{FLAG}$ and 6XHis-BiP). The results with the model peptide suggested the assay worked as designed with the Alphascreen donor and acceptor beads being pulled together via their interactions with 6XHis and FLAG sequences flanking a neutral 12 amino acid linker 
sequence. Studies with the recombinant proteins showed that 61 -FLAG in the absence of 6XHis$\mathrm{BiP}$ generated a signal of equal intensity compared to when both tagged proteins were added. This suggested that $\sigma 1$-FLAG was interacting with both the FLAG-Ab acceptor bead, and the nickel-chelate donor bead. Added detergent or lipid (PC) did not appear to discourage the interaction of $\sigma 1$-FLAG with the nickel chelate bead. It is interesting that the very high concentrations of sigma ligands tested in the experiments with neat buffer (without detergent or lipid) did not appear to affect this interaction, although this is not certain as ligand was not added to a sample containing $\sigma 1$-FLAG alone; it was only tested in the presence of $\sigma 1-\mathrm{FLAG}+6 \mathrm{XHis}-$ BiP. For samples prepared with $0.2 \%$ CHAPS, PC or CHAPS/PC, the addition of sigma ligands increased the signal relative to samples containing $\sigma 1$-FLAG or $\sigma 1$-FLAG +6 XHis-BiP alone. This suggests that binding of sigma ligand to o1-FLAG may have occurred in these samples and that this interaction increases the association of $\sigma 1$-FLAG with the donor bead, increases the

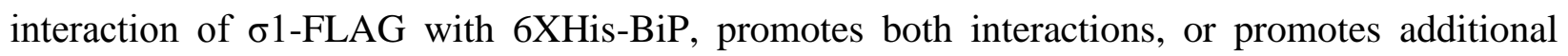
non-specific interactions of either or both proteins with the beads. Because no samples were prepared containing only $\sigma 1-\mathrm{FLAG}$ or $6 \mathrm{XHis-BiP}$ this cannot be reconciled with the current data. It was known that divalent cations can non-competitively inhibit the binding of $\left[{ }^{3} \mathrm{H}\right](+)-$ pentazocine to guinea-pig cerebellum membranes [38] but it was not anticipated that this would result in $\sigma 1$-FLAG associating with the nickel-chelate donor bead. However, the association may be the result of other non-specific interactions unassociated with the bead bound $\mathrm{Ni}^{+2}$, but because CHAPS or added lipid did not disrupt this interaction, it does not appear to be a result of non-specific hydrophobic interactions.

Because of the unanticipated interaction of $\sigma 1-F L A G$ with the nickel chelate bead, a simplified system was adopted in an effort to capture $\sigma 1$-FLAG and/or a $\sigma 1$-FLAG/6XHis-BiP complex with subsequent detection by Western blot. This system mimicked Hayashi and Su's [3] pulldown of recombinant BiP using the GST-Sig-1R116-223 construct. An NP-40 based buffer was used as assay buffer in their experiments, suggesting that the $\sigma 1 / \mathrm{BiP}$ interaction can occur in the absence of lipids, similar to the interaction of purified $\sigma 1$ with ligands [40]. Therefore, to test if this buffer would support capture of the $\sigma 1$-FLAG fusion protein used in our Alphascreen assay, and to test if this system could support a detectable $\sigma 1 / \mathrm{BiP}$ interaction, a conventional immunoprecipitation procedure was performed with a FLAG affinity matrix. In this experiment 
the bacterial alkaline phosphatase-FLAG control was immunoprecipitated but the $\sigma 1$-FLAG was not. Because this material appeared to interact readily with the Alphascreen beads in the PBS, CHAPS and phosphatidylcholine buffers, this result suggests that $\sigma 1$-FLAG may aggregate in the NP-40 buffer preventing interaction with the FLAG affinity matrix. Successful Western blot detection of the $\sigma 1$-FLAG control samples loaded directly on the gel, blotted with the FLAG antibody, supports this assumption.

Based on the results observed in our studies and more recent work of Hayashi and Fujimoto [34] and $\mathrm{Ha}$ et al. [15], a number of alternative experiments are proposed. Briefly, the easiest experiment to perform would be to acquire a rabbit derived $\sigma 1$ antibody similar to the one prepared by $\mathrm{Ha}$ et al. [15], and duplicate their sample preparation and immunoprecipitation procedure [15]. Samples would consist of RGC-5 cells exposed in situ to sigma ligands and samples prepared by exposing lysates from naïve RGC-5 cells exposed exogenously to sigma ligands. This system may very quickly verify or negate the validity of the overall approach and provide most of the information necessary to design the appropriate Alphascreen scheme. In the absence of an available rabbit derived $\sigma 1$ antibody our chicken antibody should be biotinylated, captured on streptavidin coated magnetic beads, and used in immunoprecipitation with RGC-5 lysates as described above. A second potential input for the assay which precludes the isolation of MAM by Percoll gradient centrifugation involves preparing Tx-114 detergent resistant membranes (DRM) from CHO cells using an adaptation of the method described by Hayashi and Fujimoto as outlined in Figure 8 [34]. Hayashi and Fujimoto demonstrated that the DRM obtained by Tx-114 solubilization of CHO cells is essentially the same material that is isolated from P2 using Percoll gradient centrifugation [34] and thus may provide a more reliable method for obtaining MAM from $\mathrm{CHO}$ cells.

The efforts presented in this study would have benefited from better Western blot characterization of the solubilized rat P2 membranes and CHO lysates isolates prior to their use in experiments. The inability to produce a usable blot with our BiP antibodies was also a major hindrance. The experiment testing the ability to capture $\sigma 1$ or BiP by passive adsorbtion of antibodies on an ELISA sample plate did not inform us if this was the result of a poor antibody antigen interaction or if the antibodies were poorly oriented on the plastic surface. As stated 
previously it would have been preferable to biotinylate our custom $\sigma 1$ antibody and present it via a streptavidin coated plate or bead. Lastly, while some useful information was learned about the basic operation of Alphascreen, the experiments were inconclusive with regard to its future use in an assay based on the interaction of $\sigma 1$ and $\mathrm{BiP}$.

Future efforts should emphasize the use of tissue or cultured cell derived, constitutively generated, $\sigma 1 / \mathrm{BiP}$ complex as this alleviates the necessity of extensive molecular biology efforts and the possibility that overexpression systems may not faithfully reproduce the functional interaction that occurs in vivo or that affinity tags interfere with the $\sigma 1 / \mathrm{BiP}$ interaction. Similarly, a cell free system utilizing purified recombinant affinity tagged proteins would likely require significant effort to reconstitute in an artificial lipid environment, which we now know should be highly enriched in cholesterol and ceramide. Additionally if phosphorylation of $\sigma 1$ does indeed regulate its interaction with $\mathrm{BiP}$, biological sources of $\sigma 1$ and $\mathrm{BiP}$ may be the only way to faithfully recapitulate the endogenous situation in a model system. Because the Alphascreen platform can accommodate the use of almost any antibody, the primary limitation that would preclude its use would be incompatibility with the detergent solutions utilized to isolate functional $\sigma 1 / \mathrm{BiP}$ complexes identified using immunoprecipitation.

In conclusion, we did not determine if Alphascreen will provide a suitable platform for the analysis of $\sigma 1$ functional activities based on the interaction of $\sigma 1$ and BiP. The current studies also failed to determine if the $\sigma 1 / \mathrm{BiP}$ interaction can be observed with recombinant affinity tagged fusion proteins in buffer or simple detergent or lipid solutions. While the choice of the nickel chelate donor bead was unfortunate it is not clear why $\sigma 1$ interacts with this material with such high avidity. The $\sigma 1$-FLAG protein appears to interact with the FLAG acceptor bead in PBS buffer and $0.2 \%$ CHAPS (presumably via antigen:antibody interaction) but the FLAG tag appears to be unavailable for binding with the anti-FLAG affinity matrix in a simple NP-40 buffer. Our experiments also did not determine if solubilized rat liver P2 or CHO cells would serve as a suitable input for Alphascreen; however, the use of biotinylated or IgG antibodies with conventional immunoprecipitation on streptavidin or protein $\mathrm{A} / \mathrm{G}$ matrices would likely provide more definitive answers than the passive adsorbtion of antibodies used in our studies. Use of wild-type $\mathrm{CHO}$ or rat liver isolates may require extensive experimentation with detergents, or 
additional purification to yield $\sigma 1$ enriched material, but may be as simple as isolating Tx-114 DRM from either receptor source. However, prior to embarking on any additional new approaches it is reasonable to propose that the RGC- 5 cell/detergent cocktail utilized by Ha et al. [15] may provide the simplest means for determining if the $\sigma 1 / \mathrm{BiP}$ complex in lysates exposed exogenously to sigma ligands behaves as it does in intact cells. 


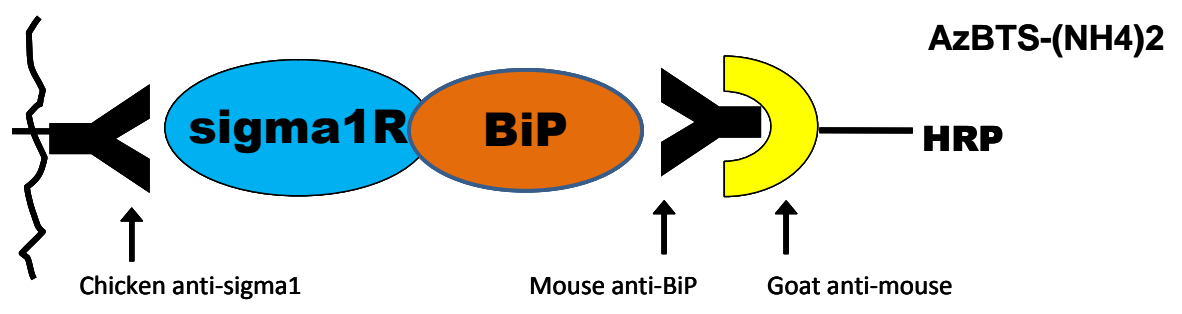

Figure 1. General scheme for detection of tissue or cultured cell derived $\sigma 1 / \mathrm{BiP}$ complex using ELISA platform.

A

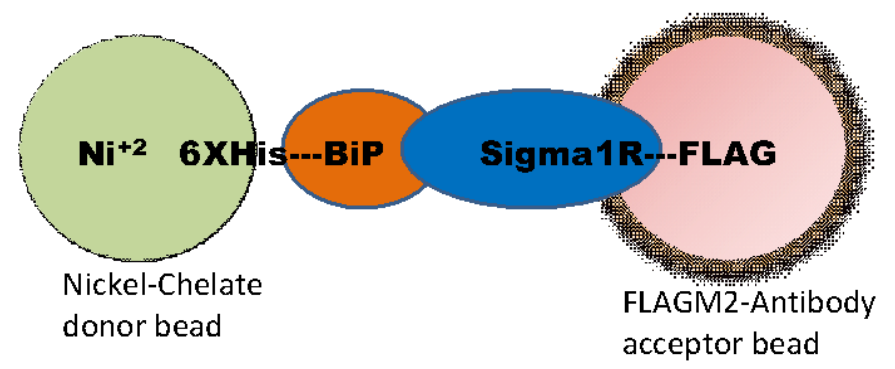

B

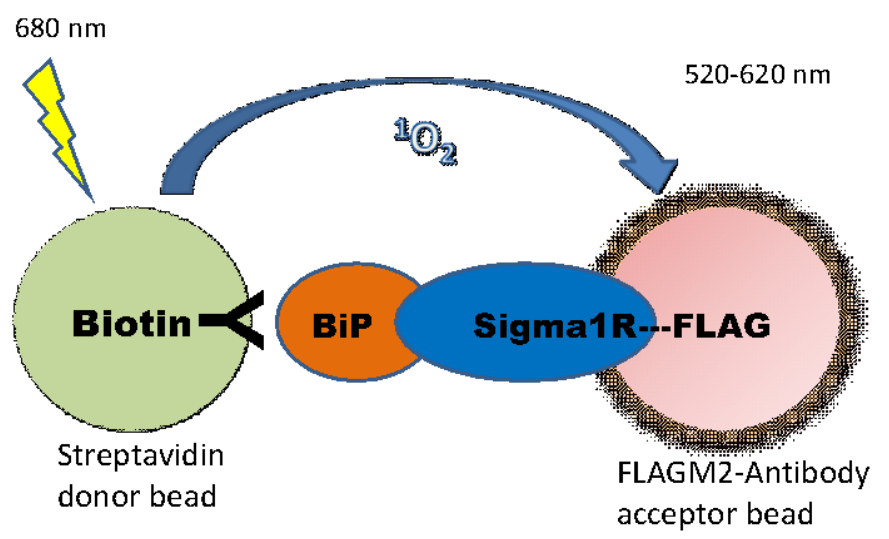

Figure 2. General scheme for detection of interaction of $\sigma 1$-FLAG with (A) 6XHis-BiP or (B) endogenous BiP. 


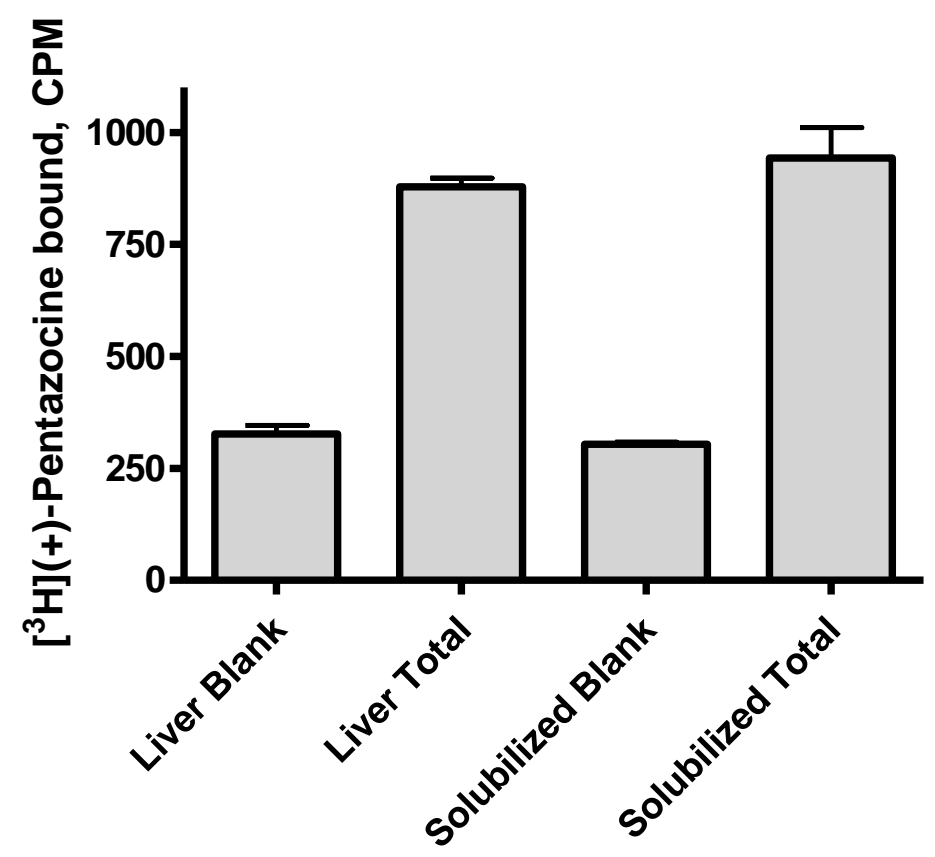

Figure 3. Binding of $\left[{ }^{3} \mathrm{H}\right](+)$-pentazocine to rat liver $\mathrm{P} 2$ and $\mathrm{P} 2$ solubilized in $0.2 \%$ CHAPS. Approximately $25 \mu \mathrm{g}$ total protein was incubated with $5 \mathrm{nM}\left[{ }^{3} \mathrm{H}\right](+)$-pentazocine in the presence (blank) or absence (total) of $10 \mu \mathrm{M}$ haloperidol. Data are averages of triplicate determinations; error bars indicate the standard error of the mean. 


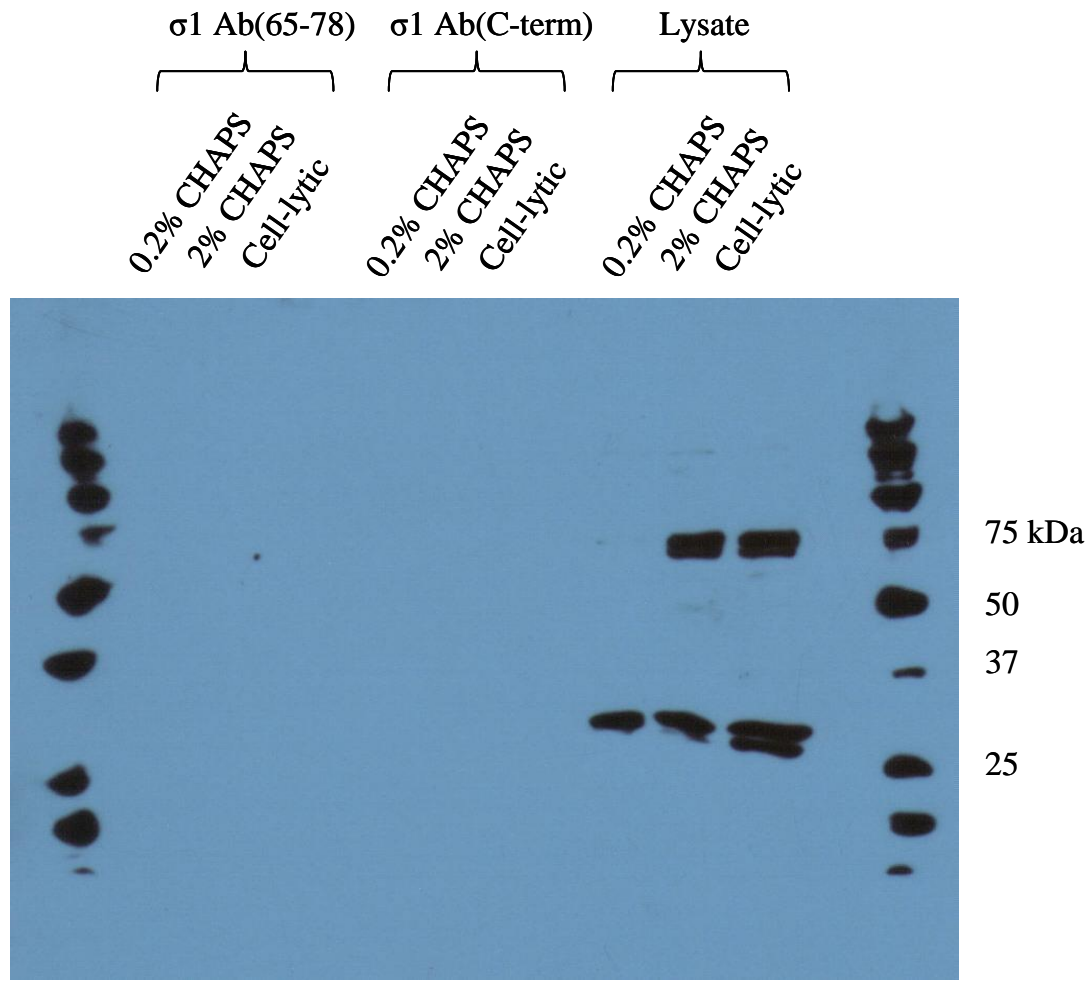

Figure 4. Western blot following attempt to capture $\sigma 1$ from $\mathrm{CHO}$ cell lysates on antibody coated 96-well ELISA plates. Blot was probed with Aves $\sigma 1$ antibody. Note that the band at $\sim 75$ $\mathrm{kDa}$ that is prominent in the 2\% CHAPS and CelLytic M lysates is absent in the $0.2 \%$ CHAPS sample. 


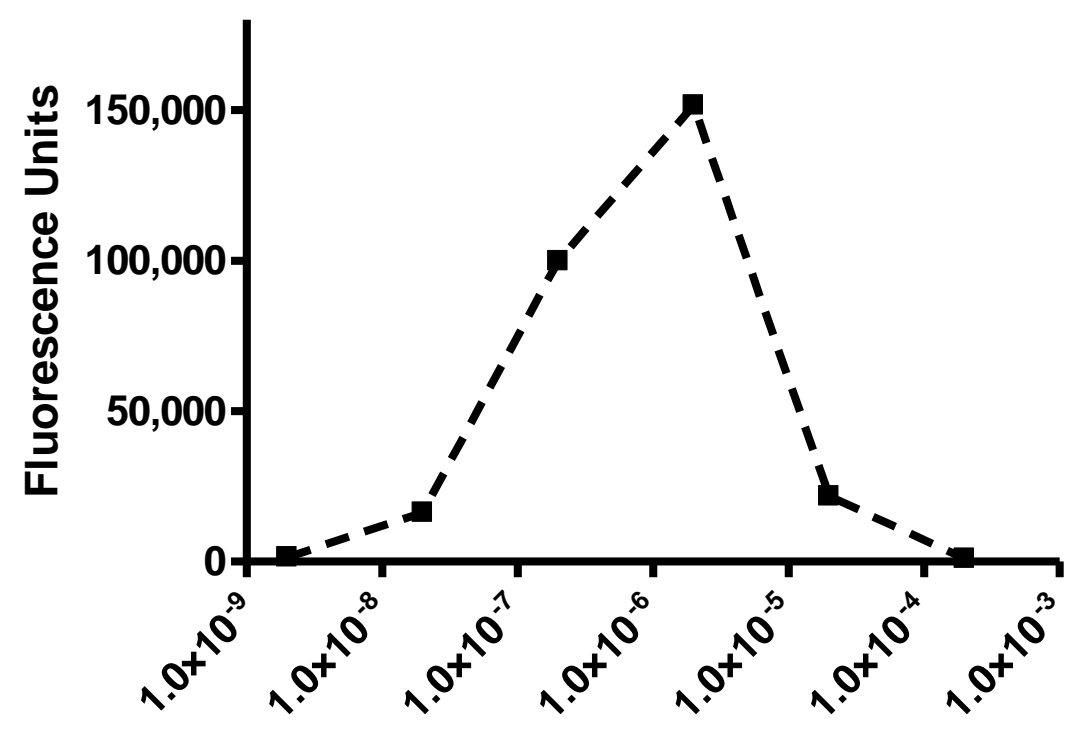

[6XHis-FLAG control peptide, M]

Figure 5. Titration of Alphascreen beads with control peptide shows a wide dynamic range, low signal to background ratio, and the expected "hooking" effect at high peptide concentrations. Samples contained $20 \mu \mathrm{g} / \mathrm{ml}$ donor and acceptor Alphascreen beads and varying concentrations of the 6X-His/FLAG control peptide in 1X Alphascreen universal buffer (PBS) in a total volume of $50 \mu \mathrm{l} / \mathrm{sample}$. The EC50 for this interaction was $~ 125 \mathrm{nM}$. 


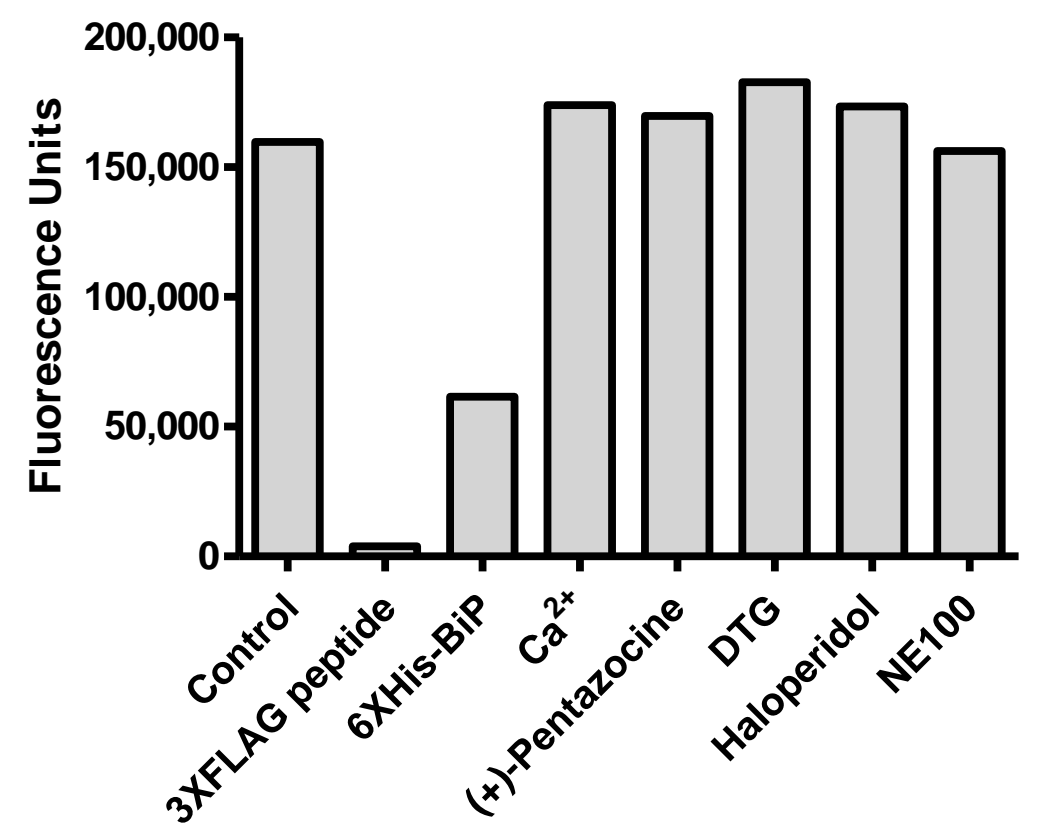

Figure 6. Effect of added $\mathrm{CaCl}_{2}$, sigma ligand, or competitor for donor or acceptor beads. Purified 3XFLAG peptide and recombinant 6XHis-BiP were capable of reducing signal derived from the control peptide, presumably via competitive interaction with the acceptor and donor beads respectively. Samples contained $20 \mu \mathrm{g} / \mathrm{ml}$ donor and acceptor Alphascreen beads, $200 \mathrm{nM}$ 6X-His-FLAG control peptide and the indicated test ligands in $1 \mathrm{X}$ Alphascreen universal buffer in a total volume of $50 \mu \mathrm{l} / \mathrm{sample}$. $\mathrm{CaCl}_{2}$ and sigma ligands were at $1 \mathrm{mM}$ and $10 \mu \mathrm{M}$ final concentration respectively. Data are averages of duplicate samples prepared for each condition tested. 
Table 1. Alphascreen signal produced by recombinant $\sigma 1-$ FLAG and 6 XHis-BiP versus control peptide. Samples contained $50 \mathrm{nM} \sigma 1$-FLAG and/or $50 \mathrm{nM}$ 6XHis-BiP, $0.5 \mathrm{mM} \mathrm{CaCl}_{2}$, and 20 $\mu \mathrm{g} / \mathrm{ml}$ donor and acceptor bead in PBS pH 7.2 with $0.05 \%$ BSA. Proteins, $\mathrm{CaCl}_{2}$, EDTA and ligands were pre-incubated 1 hour prior to bead addition. Samples with added sigma ligand contained $100 \mathrm{nM}$ or $10 \mu \mathrm{M}$ ligand as indicated. Tabulated data are averages of duplicate samples prepared for each condition tested.

\begin{tabular}{|c|c|c|c|c|}
\hline \multirow{2}{*}{ Sample } & \multicolumn{4}{|c|}{ Fluorescence Units } \\
\hline & $\mathrm{PBS}^{1}$ & $0.2 \%$ CHAPS $^{2}$ & $\mathrm{PC}^{2}$ & $0.2 \%$ CHAPS $/ \mathrm{PC}^{2}$ \\
\hline Blank & 9096 & 3714 & & 7932 \\
\hline$\sigma 1-\mathrm{FLAG}+6$ XHis-BiP & 63761 & 8086 & 23439 & 20060 \\
\hline$\sigma 1$-FLAG & 56020 & 7849 & 24433 & 22768 \\
\hline 6XHis-BiP & 12079 & 4175 & 13184 & 18980 \\
\hline$\sigma 1+\mathrm{BiP}+(+)$-pentazocine & 65710 & 11950 & 53432 & 26247 \\
\hline$\sigma 1+\mathrm{BiP}+\mathrm{NE} 100$ & 70443 & 11813 & 58370 & 29503 \\
\hline$\sigma 1+\mathrm{BiP} \mathrm{No} \mathrm{CaCl}_{2}$ & 62477 & - & - & - \\
\hline$\sigma 1+\mathrm{BiP}+\mathrm{EDTA}$ & 25944 & - & - & - \\
\hline Peptide & 137698 & 47358 & 90100 & 60506 \\
\hline Peptide $+(+)$-pentazocine & 122370 & 37220 & 87748 & 50884 \\
\hline Peptide + NE100 & 115377 & 43999 & 99429 & 48921 \\
\hline Peptide $\mathrm{No} \mathrm{CaCl}_{2}$ & 121883 & - & - & - \\
\hline Peptide + EDTA & 31941 & - & - & - \\
\hline
\end{tabular}

${ }^{1}[$ Sigma ligand $]=10 \mu \mathrm{M}$

${ }^{2}$ [Sigma ligands $]=100 \mathrm{nM}$ 


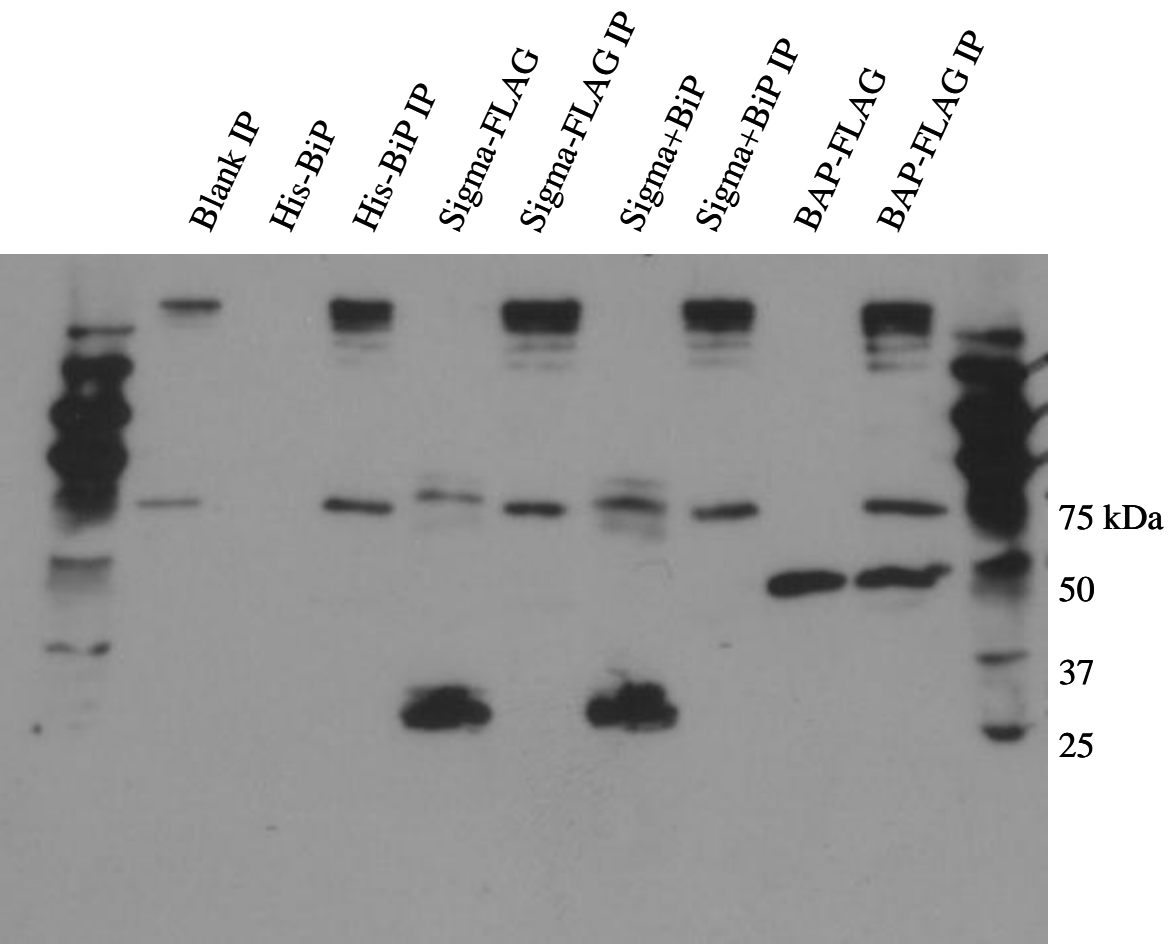

Figure 7. FLAG pulldown of $\sigma 1-F L A G$ and BAP-FLAG. Contiguous lanes contain nonimmunoprecipitated controls alongside the indicated immunoprecipitated protein(s). The PVDF membrane was blotted with FLAG-Ab. Lane 1 is a blank immunoprecipitate control. Lanes 4 and 6 show a strong band for $\sigma 1-\mathrm{FLAG}(\sim 25 \mathrm{kDa})$ that is absent in immunoprecipitated matching samples in lane 5 and 7. The bacterial alkaline phosphatase-FLAG sample in lane 9 shows that BAP-FLAG is successfully immunoprecipiated under these conditions. 


\section{Preparation of Tx-114 DRM from tissue or cells}

$0.5 \%$ Tx-114, $10 \mathrm{mM}$ Tris 7.4,

$150 \mathrm{mM} \mathrm{NaCl}, 5 \mathrm{mM}$ EDTA,

PMSF and aprotinin

$30 \mathrm{~m} @ 4^{\circ} \mathrm{C}$

Sonicate $10 \mathrm{~s} \times 3$

Centrifuge $20 \mathrm{~m}$ at $12,000 \mathrm{xg}$
DRM from 2) into $0.2 \%$ CHAPS, 10

$\mathrm{mM}$ Tris 7.4, $2 \mathrm{~h} @ 4^{\circ} \mathrm{C}$

Centrifuge supernatent from step 1, containing DRM, for 60 $\mathrm{m}$ at $100,000 \mathrm{xg}$

Centrifuge $60 \mathrm{~m}$ at $100,000 \mathrm{xg}$
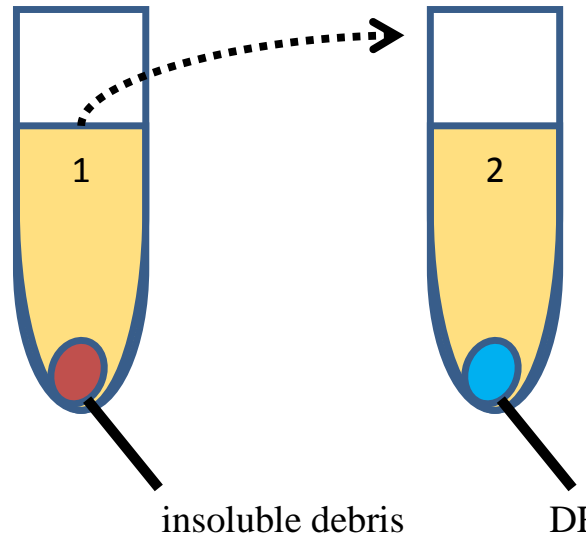

DRM containing sigma1R

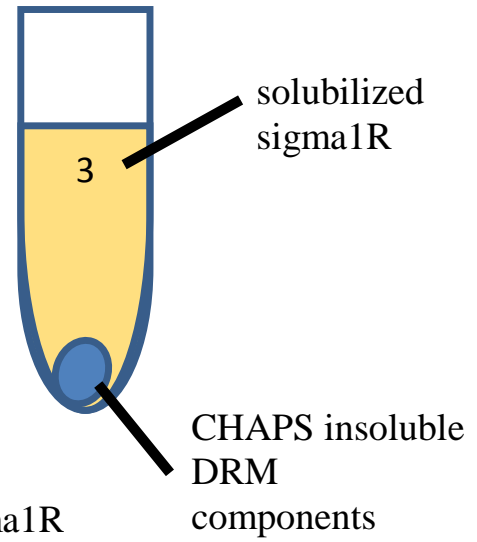

Figure 8. Procedure for preparation of $\sigma 1 / M A M$ enriched fractions with Tx-114. Samples are lysed in $0.5 \% \mathrm{Tx}-114$ buffer followed by centrifugation at $12,000 \mathrm{x} \mathrm{g}$. The resulting supernatant is centrifuged at $100,000 \mathrm{x} \mathrm{g}$ to pellet $\sigma 1 / \mathrm{DRM}$. The resulting pellet is solubilized in $0.2 \%$ CHAPS buffer. Samples should be analyzed for the presence of $\sigma 1$ and BiP prior to use in immunoprecipitations for the $\sigma 1 / \mathrm{BiP}$ complex and subsequent testing of the isolated complex for sensitivity to exogenously added sigma ligands. 


\subsection{References}

1. Herrera, Y., et al., sigma-1 receptor modulation of acid-sensing ion channel a (ASICla) and ASICla-induced Ca2+ influx in rat cortical neurons. J Pharmacol Exp Ther, 2008. 327(2): p. 491-502.

2. $\quad \mathrm{Su}, \mathrm{T} . \mathrm{P} .$, et al., The sigma-1 receptor chaperone as an inter-organelle signaling modulator. Trends Pharmacol Sci, 2010. 31(12): p. 557-66.

3. Hayashi, T. and T.P. Su, Sigma-1 receptor chaperones at the ER-mitochondrion interface regulate Ca(2+) signaling and cell survival. Cell, 2007. 131(3): p. 596-610.

4. Hayashi, T. and T.P. Su, Regulating ankyrin dynamics: Roles of sigma-1 receptors. Proc Natl Acad Sci U S A, 2001. 98(2): p. 491-6.

5. Aydar, E., et al., The sigma receptor as a ligand-regulated auxiliary potassium channel subunit. Neuron, 2002. 34(3): p. 399-410.

6. Johannessen, M., et al., Voltage-gated sodium channel modulation by sigma-receptors in cardiac myocytes and heterologous systems. Am J Physiol Cell Physiol, 2009. 296(5): p. C1049-57.

7. Maurice, T. and T.P. Su, The pharmacology of sigma-1 receptors. Pharmacol Ther, 2009. 124(2): p. 195-206.

8. Su, T.P. and T. Hayashi, Understanding the molecular mechanism of sigma-1 receptors: towards a hypothesis that sigma-1 receptors are intracellular amplifiers for signal transduction. Curr Med Chem, 2003. 10(20): p. 2073-80.

9. Tchedre, K.T., et al., Sigma-1 receptor regulation of voltage-gated calcium channels involves a direct interaction. Invest Ophthalmol Vis Sci, 2008. 49(11): p. 4993-5002.

10. Yamamoto, H., et al., Sigma ligands indirectly modulate the NMDA receptor-ion channel complex on intact neuronal cells via sigma 1 site. J Neurosci, 1995. 15(1 Pt 2): p. 731-6. 
11. Su, T.P., T. Hayashi, and D.B. Vaupel, When the endogenous hallucinogenic trace amine N,N-dimethyltryptamine meets the sigma-1 receptor. Sci Signal, 2009. 2(61): p. pe12.

12. Hashimoto, K. and K. Ishiwata, Sigma receptor ligands: possible application as therapeutic drugs and as radiopharmaceuticals. Curr Pharm Des, 2006. 12(30): p. 385776.

13. Hayashi, T. and T.P. Su, Intracellular dynamics of sigma-1 receptors (sigma(1) binding sites) in NG108-15 cells. J Pharmacol Exp Ther, 2003. 306(2): p. 726-33.

14. Mavlyutov, T.A. and A.E. Ruoho, Ligand-dependent localization and intracellular stability of sigma-1 receptors in CHO-K1 cells. J Mol Signal, 2007. 2: p. 8.

15. Ha, Y., et al., Sigma receptor 1 modulates endoplasmic reticulum stress in retinal neurons. Invest Ophthalmol Vis Sci, 2011. 52(1): p. 527-40.

16. Wu, Z. and W.D. Bowen, Role of sigma-1 receptor $C$-terminal segment in inositol 1,4,5trisphosphate receptor activation: constitutive enhancement of calcium signaling in MCF-7 tumor cells. J Biol Chem, 2008. 283(42): p. 28198-215.

17. Gonzalez, G.M. and L.L. Werling, Release of [3H]dopamine from guinea pig striatal slices is modulated by sigmal receptor agonists. Naunyn Schmiedebergs Arch Pharmacol, 1997. 356(4): p. 455-61.

18. Colabufo, N.A., et al., In vitro and ex vivo characterization of sigma-1 and sigma-2 receptors: agonists and antagonists in biological assays. Cent Nerv Syst Agents Med Chem, 2009. 9(3): p. 161-71.

19. Takebayashi, M., T. Hayashi, and T.P. Su, Nerve growth factor-induced neurite sprouting in PC12 cells involves sigma-1 receptors: implications for antidepressants. J Pharmacol Exp Ther, 2002. 303(3): p. 1227-37.

20. Cobos, E.J., J.M. Baeyens, and E. Del Pozo, Phenytoin differentially modulates the affinity of agonist and antagonist ligands for sigma 1 receptors of guinea pig brain. Synapse, 2005. 55(3): p. 192-5. 
21. DeHaven-Hudkins, D.L., et al., Allosteric modulation of ligand binding to $[3 H](+)$ pentazocine-defined sigma recognition sites by phenytoin. Life Sci, 1993. 53(1): p. 41-8.

22. Nahas, R.I., J.R. Lever, and S.Z. Lever, Synthesis and structure-activity relationships of $N$-(3-phenylpropyl)-N'-benzylpiperazines: Potent ligands for sigmal and sigma2 receptors. Bioorg Med Chem, 2008. 16(2): p. 755-61.

23. Cobos, E.J., et al., Differences in the allosteric modulation by phenytoin of the binding properties of the sigmal ligands $[3 H](+)$-pentazocine and [3H]NE-100. Synapse, 2006. 59(3): p. 152-61.

24. Nishimura, T., et al., Potentiation of nerve growth factor-induced neurite outgrowth by fluvoxamine: role of sigma-1 receptors, IP3 receptors and cellular signaling pathways. PLoS One, 2008. 3(7): p. e2558.

25. Eglen, R.M., et al., The use of AlphaScreen technology in HTS: current status. Curr Chem Genomics, 2008. 1: p. 2-10.

26. Bielefeld-Sevigny, M., AlphaLISA immunoassay platform- the "no-wash" highthroughput alternative to ELISA. Assay Drug Dev Technol, 2009. 7(1): p. 90-2.

27. AlphaLISA® Assay Development Guide, PerkinElmer Inc.

28. A Practical Guide to working with AlphaScreen. 2004, PerkinElmer, Inc.

29. Schuster, D.I., F.J. Arnold, and R.B. Murphy, Purification, pharmacological characterization and photoaffinity labeling of sigma receptors from rat and bovine brain. Brain Res, 1995. 670(1): p. 14-28.

30. Chaki, S., et al., Solubilization and characterization of binding sites for [3H]NE-100, a novel and potent sigma 1 ligand, from guinea pig brain. Life Sci, 1996. 59(16): p. 133140. 
31. Kavanaugh, M.P., et al., Solubilization and characterization of sigma-receptors from guinea pig brain membranes. J Neurochem, 1989. 53(5): p. 1575-80.

32. McCann, D.J. and T.P. Su, Solubilization and characterization of haloperidol-sensitive (+)-[3H]SKF-10,047 binding sites (sigma sites) from rat liver membranes. J Pharmacol Exp Ther, 1991. 257(2): p. 547-54.

33. Heerklotz, H., Triton promotes domain formation in lipid raft mixtures. Biophys J, 2002. 83(5): p. 2693-701.

34. Hayashi, T. and M. Fujimoto, Detergent-resistant microdomains determine the localization of sigma-1 receptors to the endoplasmic reticulum-mitochondria junction. Mol Pharmacol, 2010. 77(4): p. 517-28.

35. Palmer, C.P., et al., Sigma-1 receptors bind cholesterol and remodel lipid rafts in breast cancer cell lines. Cancer Res, 2007. 67(23): p. 11166-75.

36. Carnally, S.M., et al., Demonstration of a direct interaction between sigma-1 receptors and acid-sensing ion channels. Biophys J, 2010. 98(7): p. 1182-91.

37. Bradford, M.M., A rapid and sensitive method for the quantitation of microgram quantities of protein utilizing the principle of protein-dye binding. Anal Biochem, 1976. 72: p. 248-54.

38. Basile, A.S., et al., Modulation of (+)-[3H]pentazocine binding to guinea pig cerebellum by divalent cations. Mol Pharmacol, 1992. 42(5): p. 882-9.

39. Butler, J.E., et al., The physical and functional behavior of capture antibodies adsorbed on polystyrene. J Immunol Methods, 1992. 150(1-2): p. 77-90.

40. Ramachandran, S., et al., Purification and characterization of the guinea pig sigma-1 receptor functionally expressed in Escherichia coli. Protein Expr Purif, 2007. 51(2): p. 283-92. 


\section{SUMMARY}

In conclusion, our studies have resulted in: 1) the characterization of a new $\sigma 1$ receptor selective radioligand, and demonstration of its utility in competition binding studies, 2) the development, validation and application of a new 96-well filtration based radioligand binding method for the analysis of sigma receptor ligands, and 3) demonstration that scintillation proximity assay (SPA) technology is a suitable platform for radioligand binding studies of sigma receptor ligands. Efforts to demonstrate that the ligand sensitive interaction of the $\sigma 1$ receptor with binding immunoglobulin protein (BIP) can form the basis of an in vitro functional assay for $\sigma 1$ receptor activity were unsuccessful; however, the studies performed and the presentation of the concept may provide useful information for future efforts by other researchers.

Our studies show that $\left[{ }^{3} \mathrm{H}\right] \mathrm{SN} 56$ can serve as an alternative to $\left[{ }^{3} \mathrm{H}\right](+)$-pentazocine in radioligand binding assays. $\left[{ }^{3} \mathrm{H}\right] \mathrm{SN} 56$ exhibits saturable and reversible binding to a single high affinity site in rat brain membranes that corresponds to the site labeled by the selective $\sigma 1$ receptor radioligand $\left[{ }^{3} \mathrm{H}\right](+)$-pentazocine. Further, because SN56 is a $\sigma 1$ receptor antagonist, while $(+)$ pentazocine is an agonist, future studies with the radiolabeled forms of these ligands may reveal information that distinguishes functionally active versus inactive ligands. Therefore, our characterization of $\left[{ }^{3} \mathrm{H}\right] \mathrm{SN} 56$ demonstrates that this radioligand represents an important new tool for sigma receptor research.

The 96-well filtration based competition binding assay presented in this dissertation is a significant improvement over the conventional Brandel filtration based method. The 96-well method reduces waste and increases throughput dramatically while generating comparable data relative to the conventional method. Excellent correlations were observed between the two methods for the determination of binding to both $\sigma 1$ and $\sigma 2$ subtypes despite the use of different assay formats and tissue source for sigma receptors. The validity of the method was further demonstrated by a successful structure-binding affinity analysis of a novel series of 2(3H)benzothiazolone sigma receptor ligands. The study of this compound series identified several new high affinity $\sigma 1$ selective ligands and generated data which will be useful for the 
development of pharmacophore models for both sigma receptor subtypes, and consequently provides for the rational design of future novel sigma ligands.

Our preliminary assessment of SPA for use in competition binding assays of sigma receptor ligands suggests this technology has promise for future use in high throughput screening (HTS). Currently there are some issues that need to be resolved before the method is generally applicable, which include: a high background signal, very long incubation times, and a relatively high per sample cost for SPA beads. These problems may be resolved through the use of more highly purified tissue membrane preparations, cells lines overexpressing sigma receptors and/or the use of radioligands with higher specific activities. Because this method is amenable to HTS it may be desirable to continue further development; this depends largely on the interest of the science community in sigma receptor based therapeutics.

Our studies supporting the development of a high throughput in vitro functional assay for $\sigma 1$ ligands based on the agonist sensitive interaction between $\sigma 1$ and BiP were largely unsuccessful. However, the need for an in vitro functional assay remains and the rational for targeting this interaction is sound. Future efforts should focus on demonstrating that a patent $\sigma 1 / \mathrm{BiP}$ complex can be isolated using conventional immunoprecipitation methods and cell lines where the interaction has already been established. This includes wild-type Chinese hamster ovary and RGC-5 cells. The isolation of a solubilized functional complex from these cells will likely be largely dependant on finding appropriate detergent conditions. Additional efforts to adapt the method to higher throughput methods should only be attempted following demonstration that a solubilized functional complex can be isolated. 


\section{James A. Fishback}

409 Beaver Ave · Morgantown, WV, 26505 ·662-701-9709 ·jfishback@hsc.wvu.edu

\section{QUALIFICATIONS}

Seventeen years of research experience in the biotech industry emphasizing analytical methodology and its application to the development of human therapeutics. Experience encompasses broad range of disciplines including synthesis, purification, formulation, pro-drug development, bio-analytical method development, quality control and clinical research. Drug classes supported include siRNA, ribozymes, anti-sense DNA, peptides, and small molecule nucleic acid anti-virals.

\section{$\underline{\text { EDUCATION }}$}

Ph.D. Pharmacology

West Virginia University, Morgantown, WV

August, 2011

Dissertation: New methodologies for in vitro analysis of binding and functional activity of sigma ligands

Advisor: Dr. Rae R. Matsumoto, formerly University of MS

External advisor: Teruo Hayashi, NIH/NIDA

M.S. Pharmacology

University of Mississippi, Oxford, MS

2008

B.S. Chemistry

James Madison University, Harrisonburg, VA

1985

\section{AWARDS AND FELLOWSHIPS}

2010-2011 Behavioral and Biomedical Sciences Training Scholarship

$2010 \quad$ School of Pharmacy, Basic Pharmaceutical Sciences Research Award

2006-2008 Natural Products Neuroscience Fellowship

2007

Pharmacy Teaching Assistant Award

\section{PROFESSIONAL HISTORY}

\section{Sirna Therapeutics / Ribozyme Pharmaceuticals Boulder, CO}

1997- 2004

- Developed, validated and applied bio-analytical methods in support of in vivo and in vitro evaluation of siRNAs and ribozymes.

- Performed GLP analysis of pre-clinical and clinical samples of Angiozyme ${ }^{\mathrm{TM}}$, Heptazyme ${ }^{\mathrm{TM}}$, and Herzyme $^{\mathrm{TM}}$.

- Formulated, manufactured, and analyzed liposomal preparations of Angiozyme ${ }^{\mathrm{TM}}$ for evaluation of in vivo efficacy.

- Coordinated analytical activities supporting GMP manufacture of Angiozyme ${ }^{\mathrm{TM}}$. Trained and supervised three Research Associates.

- $\quad$ Monitored phase I clinical trial of Angiozyme ${ }^{\mathrm{TM}}$. 
- Developed, validated, and applied bio-analytical methods for the determination of pharmacokinetics of phosphonate nucleotide analogues and pro-drugs in support of preclinical in vivo studies.

- Applied methods to determine pharmacokinetics of Vistide ${ }^{\mathrm{TM}}$ in phase I/II human clinical trials.

- Determined pharmacokinetics and oral bioavailability of Hepsera ${ }^{\mathrm{TM}}$ in primate model.

- Transferred methods to UCSF collaborators and contract laboratories.

- Developed methods and analyzed samples of GS-522, a novel aptamer based thrombin inhibitor, to determine: 1) in vitro properties, and 2) pharmacokinetics in cynomolgus monkeys.

- Co-invented "chemically reversible" aptamers (PCT/US1993/007130). Evaluated selective triplex forming double strand cleaving oligonucleotides.

- Developed methods for large-scale purification of oligonucleotides. Performed analyses by HPLC, PAGE, sequencing and base composition analysis. Determined partition coefficients and protein binding of novel nucleotide bases.

\section{Peptide Technologies}

Washington, DC

1987 - 1988

- Synthesized peptides by Fmoc and tBoc chemistries. Purified by HPLC and counter-current chromatography.

Varex Corporation

Rockville, MD

1985 - 1987

- Applications development and customer support for preparative HPLC and GC. Quality control for product instruments.

\section{TECHNIQUES/SKILLS}

Method development, GLP validation, CE, GC, HPLC, preparative chromatography, cell culture, luciferase reporter assay, PAGE, Western, ELISA, Alphascreen ${ }^{\circledR}$, RT-PCR, Invader ${ }^{\circledR}$, competition binding, SPA, pharmacokinetics, manuscript and grant writing. 


\section{PUBLICATIONS}

1) Fishback JA, Mesangeau C, Poupaert JH, McCurdy CR, Matsumoto RR. "Synthesis and characterization of $\left[{ }^{3} \mathrm{H}\right]-\mathrm{SN} 56$, a novel radioligand for the $\sigma 1$ receptor" (2011) European Journal of Pharmacology, 653(1-3):1-7,

2) Fishback JA, Robson MJ, Xu YT, Matsumoto RR. "Sigma receptors: potential targets for a new class of antidepressant drug" (2010) Pharmacology and Therapeutics, 127(3):271-82.

3) Hsin LW, Chang LT, Rothman RB, Dersch CM, Fishback JA, Matsumoto RR. "Synthesis and opioid activity of enantiomeric N-substituted 2,3,4,4a,5,6,7,7a-octahydro-1H-benzofuro[3,2e]isoquinolines" (2010) Journal of Medicinal Chemistry, 53(3):1392-6.

4) Fishback JA, Matsumoto RR. "Development of new radioligands and assay formats for determination of binding affinities of sigma ligands" R21 submitted to NIDA, October, 2009. Grant was not funded.

5) Liu Y, Brown S, Shaikh J, Fishback JA, Matsumoto RR. "Relationship Between Methamphetamine Exposure and Matrix Metalloproteinase 9 Expression" (2008) Neuroreport, 19(14):1407-9.

6) Mésangeau C, Narayanan S, Green AM, Shaikh J, Kaushal N, Viard E, Xu YT, Fishback JA, Poupaert JH, Matsumoto RR, McCurdy CR. "Conversion of a Highly Selective Sigma-1 ReceptorLigand to Sigma-2 Receptor Preferring Ligands with Anticocaine Activity" (2008) Journal of Medicinal Chemistry, 51(5):1482-6.

7) Dai JQ, Fishback JA, Zhou YD, Nagle DG. "Sodwanones and Yardenones from the Marine Sponge Axinella sp. Inhibit Hypoxia-Inducible Factor-1 (HIF-1) Activation in Breast and Prostate Tumor Cells" (2006) Journal of Natural Products, 69(12):1715-20.

8) Cundy KC, Fishback JA, Shaw JP, Lee ML, Soike KF, Visor GC, Lee WA. "Oral Bioavailability of the Antiretroviral Agent 9-(2-phosphonylmethoxyethyl) adenine (PMEA) from Three Formulations of the Prodrug Bis(pivaloyloxymethyl)-PMEA in Fasted Male Cynomolgus Monkeys" (1994) Pharmaceutical Research, 11(6):839-843.

9) Shaw JP, Fishback JA, Cundy KC, Lee WA. "A Novel Oligodeoxynucleotide Inhibitor of Thrombin. I. In Vitro Metabolic Stability in Plasma and Serum" (1995) Pharmaceutical Research, 12(12):1937-42.

10) Lee WA, Fishback JA, Shaw JP, Bock LC, Griffin LC, Cundy KC. "A Novel Oligodeoxynucleotide Inhibitor of Thrombin. II. Pharmacokinetics in the Cynomolgus Monkey" (1995) Pharmaceutical Research, 12(12):1943-7.

11) Froehler B, Shaw JP, Kent K, Bird J, Fishback JA. "Modified Deoxyoligonucleotides Stable to Exonuclease Degradation in Serum" (1991) Nucleic Acids Research, 19(4), 747-750. 


\section{PRESENTATIONS}

1) Fishback JA, McCurdy CR, Matsumoto RR. "Evaluation of $\left[{ }^{3} \mathrm{H}\right]-\mathrm{SN} 56$, a novel sigma-1 receptor radioligand" (2009) Poster, 71 ${ }^{\text {st }}$ College on Problems of Drug Dependence (CPDD) Annual Meeting.

2) Dai, JQ, Fishback JA, Zhou, YD, Nagle, DG. "New Sodwanone and Yardenone Triterpines from a South African Axinella Sponge Inhibit HIF-1 Activation in Breast and Prostate Tumor Cells" (2006) Poster, American Society of Pharmacognosy Annual Meeting.

3) Gelmon, K, Chia, S, Chi, K, D'Aloisio, S, Ayers, D, Moore, M, Sykes, D, Radka, S, Hurliman, M, Kong L, Gilad, G, Aitchison, R, Fishback, JA, Lockridge, J, Malony, L, Lee, P. "A Phase I Study of Herzyme ${ }^{\mathrm{TM}}$, an Anti-HER2 Ribozyme, in Patients with HER2 Overexpressing Cancers" (2003) Poster, AACR Annual Meeting.

4) Fishback, JA, Jalali, K, Zinnen SP, Beigelman, L. "Development and Validation of a 96-Well SPE HPLC Method for Measurement of Heptazyme ${ }^{\mathrm{TM}}$ Levels in Cynomolgus Monkey Plasma" (2001) Poster, AAPS Annual Meeting and Exposition.

5) Fishback JA, Shaw J.P, Cundy KC, Lee WA. "An Anion Exchange HPLC Method for the Analysis of GS-0522, A Novel Oligonucleotide Inhibitor of Thrombin" (1993) Poster, 14th Intl. Symp. on HPLC of Proteins, Peptides and Polynucleotides.

6) Cundy KC, Fishback JA, Fisher PE, Flaherty JF, Glutzer EL, Lalezari JP, Drew WL, Jaffe HS. "Pharmacokinetics of the Nucleotide Analog HPMPC in HIV-Infected Patients with Assymptomatic CMV Infection" (1993) Poster, Eighth Annual Meeting American Association of Pharmaceutical Scientists.

7) Flaharty JF, Lalezari JP, Glutzer EL, Cundy KC, Fishback JA, Jaffe HS, Drew WL "Pharmacokinetics of HPMPC in HIV-Infected Men with Assymptomatic Cytomegalovirus Infection" (1993) Poster, 33rd Interscience Conference on Antimicrobial Agents and Chemotherapy. 